University of Tennessee Health Science Center

UTHSC Digital Commons

\title{
Discovery of Quinic Acid Derivatives as Oral Anti-inflammatory Agents
}

\author{
Kui Zeng \\ University of Tennessee Health Science Center
}

Follow this and additional works at: https://dc.uthsc.edu/dissertations

Part of the Alternative and Complementary Medicine Commons, Medicinal and Pharmaceutical Chemistry Commons, Natural Products Chemistry and Pharmacognosy Commons, Pharmaceutical Preparations Commons, and the Pharmaceutics and Drug Design Commons

\section{Recommended Citation}

Zeng, Kui , "Discovery of Quinic Acid Derivatives as Oral Anti-inflammatory Agents" (2010). Theses and Dissertations (ETD). Paper 314. http://dx.doi.org/10.21007/etd.cghs.2010.0371. 


\title{
Discovery of Quinic Acid Derivatives as Oral Anti-inflammatory Agents
}

\begin{abstract}
Quinic acid (QA) esters found in hot water extracts of Uncaria tomentosa (a.k.a. Cat's claw) exert antiinflammatory activity through mechanisms involving inhibition of the pro-inflammatory transcription factor nuclear factor kappa B (NF-KB). Herein, we described the synthesis and biological testing of novel QA derivatives. Inhibition of NF-KB was assessed using A549 (Type II alveolar epithelial-like) cells that stably express a secreted alkaline phosphatase (SEAP) reporter driven by an NF-KB response element. A549- NF-KB cells were stimulated with TNF- $\alpha(10 \mathrm{ng} / \mathrm{mL})$ in the presence or absence of QA derivative for 18 hours followed by measurement of SEAP activity. Amide substitution at the carboxylic acid position yielded potent inhibitors of NF-KB. A variety of modifications to the amide substitution were tolerated with the N-propyl amide derivative 3 being the most potent. Compound 3 was named as KZ-41. The NF-kB inhibitory potency $\left(\mathrm{IC}_{50}\right)$ of our most active analog $\mathrm{KZ}-41$ was determined to be $2.83 \pm 1.76 \mathrm{mM}$. Further examination of the structure and activity relationship (SAR) demonstrated that acetylation of the hydroxyl groups reduced NF-KB inhibitory activity. QA amide derivatives lacked anti-oxidant activity and were found to be neither anti-proliferative nor cytotoxic at concentrations up to $100 \mathrm{mM}$.
\end{abstract}

The dehydroxyl QA amides 18 and 20 were synthesized to retain anti-inflammatory activity while having enhanced resistance to microbial degradation. They showed NF-kB inhibition at concentration $1 \mathrm{mM}$. The extent of NF-kB inhibition was close to positive control drug dexamethasone. The dehydroxyl QA amide with a double bond 38 was also synthesized. The QA amide esters 24, 25, 29 and 33 were designed and synthesized to retain anti-inflammatory activity with additional antioxidant properties. As expected, compound 25 showed strong anti-oxidant activity. Furthermore, they were hydrolyzed by the microflora, for an example, 25 was hydrolyzed into sinapic acid (SA) and 3. Both SA and 3 will not be consumed by gut bacteria, and are easily absorbed in animal digestive tract. This was done by other researchers, and not reported here.

To facilitate pre-clinical biopharmaceutic and pharmacokinetic (B/PK) studies of our lead QA amide analog KZ-41, we developed and validated a novel hydrophilic interaction liquid chromatography-tandem mass spectrometry (HILIC-MS/MS) analytical assay. An analog of KZ-41 was used as internal standard (IS). KZ-41 and the IS were obtained by protein precipitation and separated by HILIC chromatography using acetonitrile and water. A triple quadrupole mass spectrometer operating in the negative electrospray ionization mode with multiple reaction monitoring was used to detect KZ-41 and IS transitions of $\mathrm{m} / \mathrm{z} 232 \rightarrow 178$ and $272 \rightarrow 218$ respectively. The lower limit of quantification (LLOQ) was 0.5 $\mathrm{ng} / \mathrm{mL}$ in plasma. The method was validated for selectivity, linearity, accuracy and precision in rat plasma. The ion suppression, recovery and stability of the analyte in the biological matrix were also tested. The assay developed

is rapid, sensitive and robust enough to support preclinical B/PK studies of KZ-41.

The study was also conducted to characterize the biopharmaceutics and pre-clinical pharmacokinetics of the lead QA amide analog, $K Z-41$. Rats ( $n=6 /$ group) received a dose of either an i.v. or p.o. dose (10 mg/ $\mathrm{kg}$ ) of KZ-41. Pharmacokinetic parameters were determined from concentration - time profiles by noncompartmental analysis. Bacterial stability study was conducted in cultured bacterial gluconobacter oxydans. Plasma protein binding and metabolic stability were determined using equilibrium dialysis and rat liver microsomes respectively. Following i.v. administration, KZ-41 demonstrated a medium clearance $(15.1 \pm 4.8 \mathrm{~mL} / \mathrm{min} / \mathrm{kg})$, medium volume of distribution $(3.3 \pm 1.1 \mathrm{~L} / \mathrm{kg})$, and a terminal half-life of $2.6 \pm 0.4$ hrs. KZ-41 was rapidly absorbed with complete oral bioavailability $(\mathrm{F} \approx 1)$, which was consistent with the fact that KZ-41 was not susceptible to degradation in bacterial and liver microsomal studies. KZ-41 binding to plasma proteins was about $30 \%$. These studies demonstrate that $\mathrm{KZ}-41$ is a potential new 
orally active anti-inflammatory agent.

In summary, we have discovered a novel series of non-toxic QA amides that potently inhibit NF-KB. The NF-kB inhibitory potency $\left(\mathrm{IC}_{50}\right)$ of our most active analog $\mathrm{KZ}-41$ was determined as $2.83 \pm 1.76 \mathrm{mM}$. It was rapidly absorbed with complete oral bioavailability $(F \approx 1)$. It could be a potential new orally active antiinflammatory agent. Mechanistic studies and pre-clinical efficacy studies of these newly designed compounds in various in vitro and in vivo models are on-going by other researchers, and are not reported in this dissertation.

\section{Document Type}

Dissertation

\section{Degree Name}

Doctor of Philosophy (PhD)

\section{Program}

Pharmaceutical Sciences

\section{Research Advisor}

Duane D. Miller, Ph.D.

\section{Keywords}

anti-inflammation, orally active drug, quinic acid derivatives

\section{Subject Categories}

Alternative and Complementary Medicine | Chemicals and Drugs | Medicinal and Pharmaceutical Chemistry | Medicine and Health Sciences | Natural Products Chemistry and Pharmacognosy | Pharmaceutical Preparations | Pharmaceutics and Drug Design | Pharmacy and Pharmaceutical Sciences

\section{Comments}

Two year embargo expired May 2012 


\title{
DISCOVERY OF QUINIC ACID DERIVATIVES AS ORAL
} ANTI-INFLAMMATORY AGENTS

\author{
A Dissertation \\ Presented for \\ The Graduate Studies Council \\ The University of Tennessee \\ Health Science Center
}

In Partial Fulfillment

Of the Requirements for the Degree

Doctor of Philosophy

From The University of Tennessee

By

Kui Zeng

May 2010 
Chapter 2 ( 2009 by Elsevier Ltd. All other material (c) 2010 By Kui Zeng. 


\section{DEDICATION}

To Tao, my wife; and my daughters. 


\section{ACKNOWLEDGEMENTS}

My great gratitude goes to my major mentor, Dr. Duane D. Miller for suggesting the problems, providing the guidance and hands in the research conducted in this dissertation.

My sincere appreciation goes to my faculty committee members, Dr. Charles R. Yates, Dr. Bernd Meibohm, Dr. Wei Li, and Dr. Thaddeus S. Nowak for their suggestions, assistance and encouragement during my graduate study. Especially to Dr. Yates, for his guidance in biology activity and pre-clinic pharmacokinetic study.

Thanks to members of Dr. Duane Miller's group, Dr. Yan Lu, Dr. Igor Rakov, Dr. Anjaiah Siddam, and others for their help during my work of the synthesis. I would like to thank members of Dr. Charles R. Yates's group, Dr. Leslie B. Stuart, Ms. Karin Emmons, Mr. Fei Ma for their assistance in biological and animal studies.

I would also like to thank the faculty, staff, and students of the Department of Pharmaceutical Sciences at University of Tennessee Health Science Center, Memphis.

Thanks from the bottom of my heart to my wife, Tao, and my family, for their patience and support.

Thanks for the funds from the Department of Pharmaceutical Sciences, College of Pharmacy, University of Tennessee Health Science Center, and the Van Vleet Endowed Professorship (DDM). 


\begin{abstract}
Quinic acid (QA) esters found in hot water extracts of Uncaria tomentosa (a.k.a. Cat's claw) exert anti-inflammatory activity through mechanisms involving inhibition of the pro-inflammatory transcription factor nuclear factor kappa B (NF- $\mathrm{B}$ ). Herein, we described the synthesis and biological testing of novel QA derivatives. Inhibition of NF$\kappa \mathrm{B}$ was assessed using A549 (Type II alveolar epithelial-like) cells that stably express a secreted alkaline phosphatase (SEAP) reporter driven by an NF- $\kappa$ B response element. A549- NF- $\kappa B$ cells were stimulated with TNF- $\alpha(10 \mathrm{ng} / \mathrm{mL})$ in the presence or absence of QA derivative for 18 hours followed by measurement of SEAP activity. Amide substitution at the carboxylic acid position yielded potent inhibitors of NF- $\kappa$ B. A variety of modifications to the amide substitution were tolerated with the N-propyl amide derivative 3 being the most potent. Compound 3 was named as KZ-41. The NF- $\mathrm{B}$ inhibitory potency $\left(\mathrm{IC}_{50}\right)$ of our most active analog $\mathrm{KZ}-41$ was determined to be $2.83 \pm 1.76 \mu \mathrm{M}$. Further examination of the structure and activity relationship (SAR) demonstrated that acetylation of the hydroxyl groups reduced NF- $\kappa$ B inhibitory activity. QA amide derivatives lacked anti-oxidant activity and were found to be neither antiproliferative nor cytotoxic at concentrations up to $100 \mu \mathrm{M}$.

The dehydroxyl QA amides 18 and $\mathbf{2 0}$ were synthesized to retain antiinflammatory activity while having enhanced resistance to microbial degradation. They showed NF- $\kappa$ B inhibition at concentration $1 \mu \mathrm{M}$. The extent of NF- $\kappa \mathrm{B}$ inhibition was close to positive control drug dexamethasone. The dehydroxyl QA amide with a double bond 38 was also synthesized. The QA amide esters 24, 25, 29 and 33 were designed and synthesized to retain anti-inflammatory activity with additional antioxidant properties. As expected, compound $\mathbf{2 5}$ showed strong anti-oxidant activity. Furthermore, they were hydrolyzed by the microflora, for an example, 25 was hydrolyzed into sinapic acid (SA) and $\mathbf{3}$. Both SA and $\mathbf{3}$ will not be consumed by gut bacteria, and are easily absorbed in animal digestive tract. This was done by other researchers, and not reported here.
\end{abstract}

To facilitate pre-clinical biopharmaceutic and pharmacokinetic (B/PK) studies of our lead QA amide analog KZ-41, we developed and validated a novel hydrophilic interaction liquid chromatography-tandem mass spectrometry (HILIC-MS/MS) analytical assay. An analog of KZ-41 was used as internal standard (IS). KZ-41 and the IS were obtained by protein precipitation and separated by HILIC chromatography using acetonitrile and water. A triple quadrupole mass spectrometer operating in the negative electrospray ionization mode with multiple reaction monitoring was used to detect KZ-41 and IS transitions of $\mathrm{m} / \mathrm{z} 232 \rightarrow 178$ and $272 \rightarrow 218$ respectively. The lower limit of quantification (LLOQ) was $0.5 \mathrm{ng} / \mathrm{mL}$ in plasma. The method was validated for selectivity, linearity, accuracy and precision in rat plasma. The ion suppression, recovery and stability of the analyte in the biological matrix were also tested. The assay developed is rapid, sensitive and robust enough to support preclinical B/PK studies of KZ-41.

The study was also conducted to characterize the biopharmaceutics and preclinical pharmacokinetics of the lead QA amide analog, KZ-41. Rats ( $n=6 /$ group) 
received a dose of either an i.v. or p.o. dose $(10 \mathrm{mg} / \mathrm{kg})$ of KZ-41. Pharmacokinetic parameters were determined from concentration - time profiles by non-compartmental analysis. Bacterial stability study was conducted in cultured bacterial gluconobacter oxydans. Plasma protein binding and metabolic stability were determined using equilibrium dialysis and rat liver microsomes respectively. Following i.v. administration, KZ-41 demonstrated a medium clearance $(15.1 \pm 4.8 \mathrm{~mL} / \mathrm{min} / \mathrm{kg})$, medium volume of distribution $(3.3 \pm 1.1 \mathrm{~L} / \mathrm{kg})$, and a terminal half-life of $2.6 \pm 0.4 \mathrm{hrs}$. KZ-41 was rapidly absorbed with complete oral bioavailability $(\mathrm{F} \approx 1)$, which was consistent with the fact that KZ-41 was not susceptible to degradation in bacterial and liver microsomal studies. KZ41 binding to plasma proteins was about $30 \%$. These studies demonstrate that KZ-41 is a potential new orally active anti-inflammatory agent.

In summary, we have discovered a novel series of non-toxic QA amides that

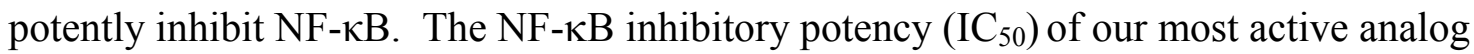
$\mathrm{KZ}-41$ was determined as $2.83 \pm 1.76 \mu \mathrm{M}$. It was rapidly absorbed with complete oral bioavailability $(\mathrm{F} \approx 1)$. It could be a potential new orally active anti-inflammatory agent. Mechanistic studies and pre-clinical efficacy studies of these newly designed compounds in various in vitro and in vivo models are on-going by other researchers, and are not reported in this dissertation. 


\section{TABLE OF CONTENTS}

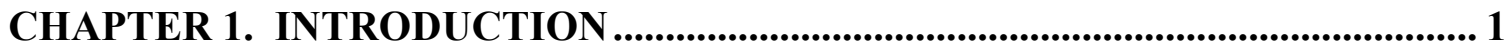

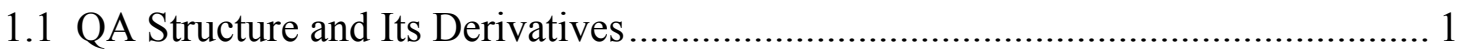

1.2 QA Biosynthesis and Catabolism ............................................................... 1

1.2.1 The QA Biosynthesis ............................................................................ 1

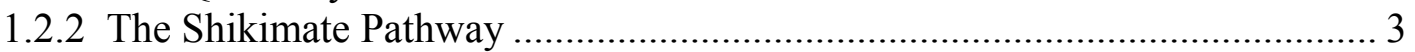

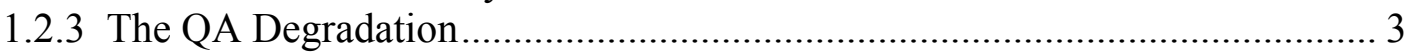

1.3 QA Degradation by Microorganisms ………….................................................. 3

1.4 Biological Activities of QA and Its Derivatives ................................................... 4

1.4.1 The Anti-inflammatory Activity of QA and CGA through NF-kB Pathway .. 5

1.4.2 The Antioxidant Effect of QA and CGA ......................................................... 6

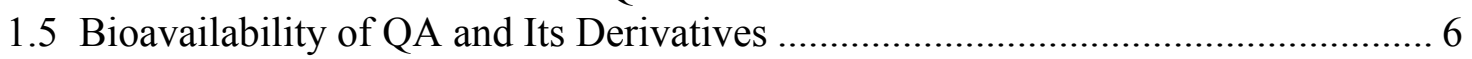

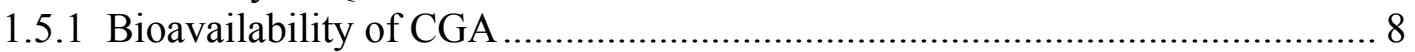

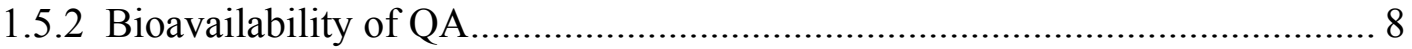

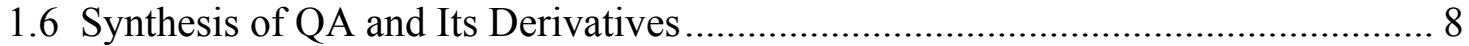

1.7 The Discovery of QA Derivatives as Oral Anti-inflammatory Agents ................. 10

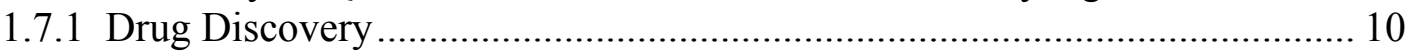

1.7.2 The Study Goals and Hypothesis ................................................................... 11

\section{CHAPTER 2. SYNTHESIS AND BIOLOGICAL EVALUATION OF QUINIC}

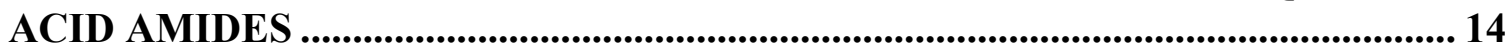

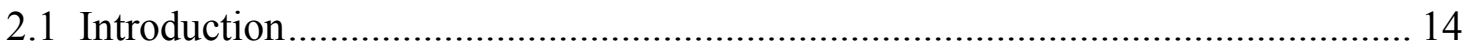

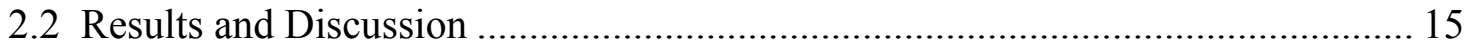

2.2.1 Synthesis of Quinic Acid Amides.......................................................... 15

2.2.2 Biology Test of Quinic Acid Amides ...................................................... 15

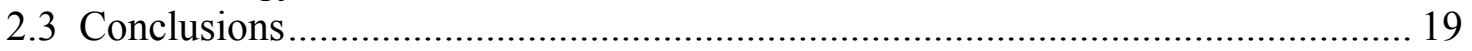

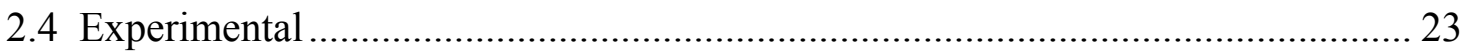

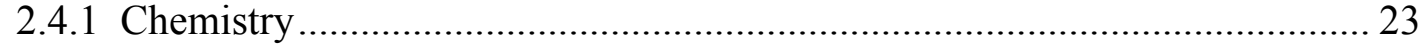

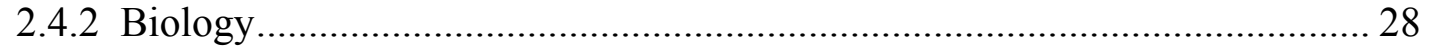

\section{CHAPTER 3. DESIGN AND SYNTHESIS OF QUINIC ACID DERIVATIVE} ESTERS AND COMPOUND WITH DOUBLE BOND................................................ 30

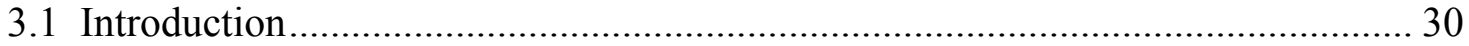

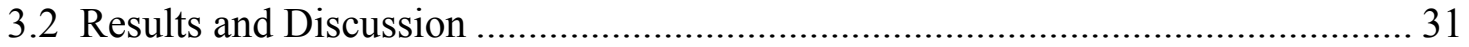

3.2.1 Synthesis of Quinic Acid Derivatives........................................................... 31

3.2.2 Biology Testing of Dehydroxyl QA Amides and Esters ............................... 35

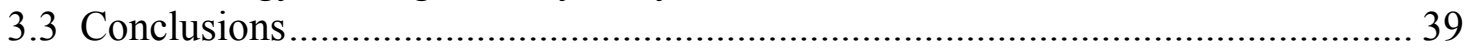

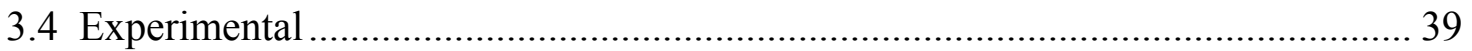

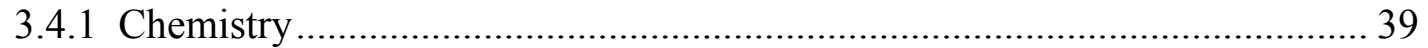

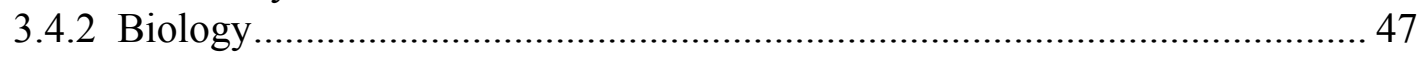




\section{CHAPTER 4. DETERMINATION OF QUINIC ACID AMIDES IN RAT PLASMA BY LC/MS/MS WITH A HYDROPHILIC INTERACTION LIQUID CHROMATOGRAPHY COLUMN...................................................................... 49}

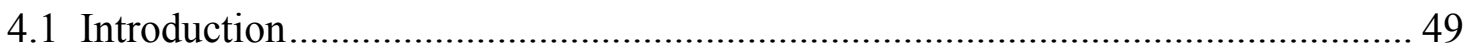

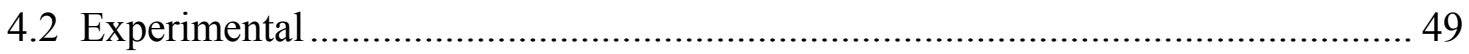

4.2.1 Material and Reagents Synthesis of Quinic Acid Amides........................... 49

4.2.2 Preparation of Calibration Standards and Quality Control Samples Biology Testing of Quinic Acid Amides ................................................................... 51

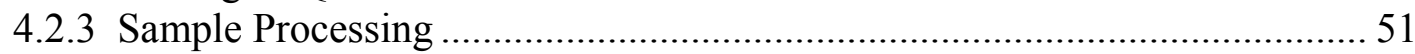

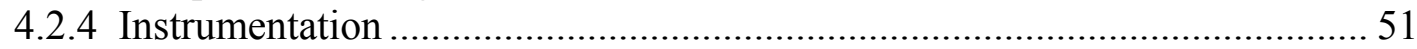

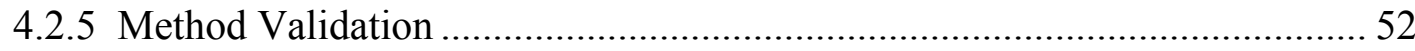

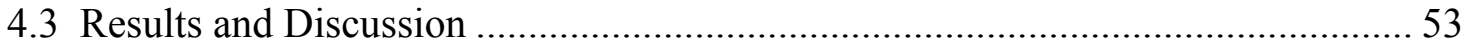

4.3.1 Optimization of Sample Preparation Procedure .......................................... 53

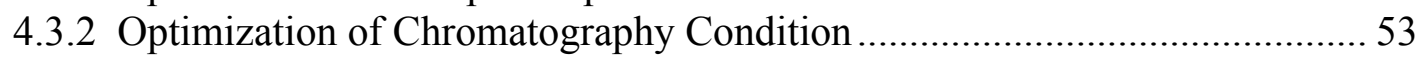

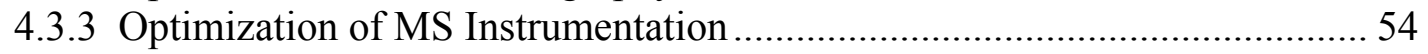

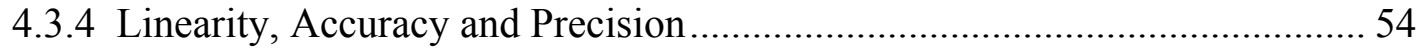

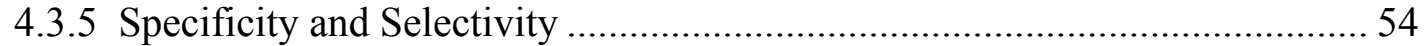

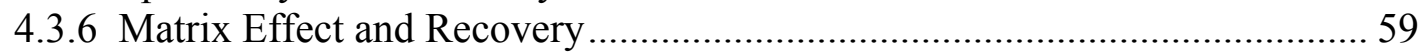

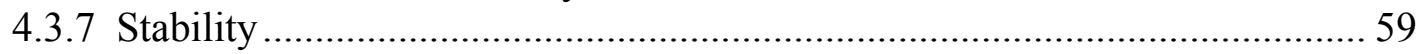

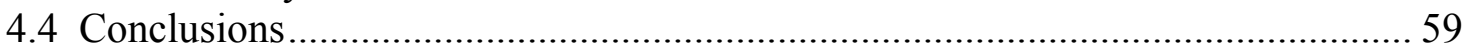

\section{CHAPTER 5. PHARMACOKENETICS AND BIOAVAILABILITY OF NOVEL}

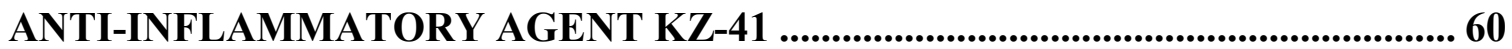

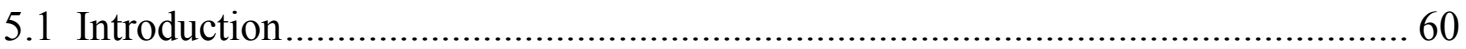

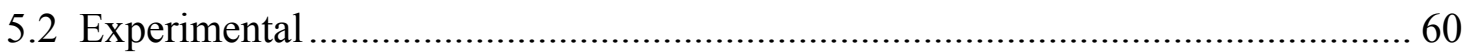

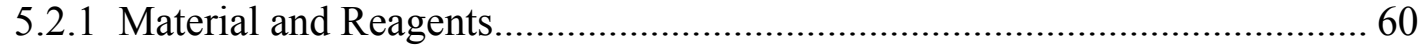

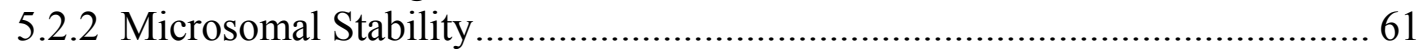

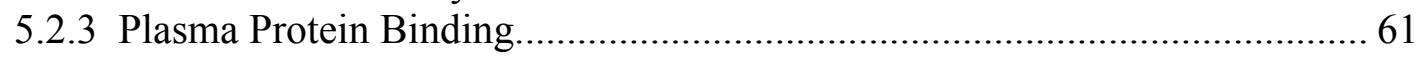

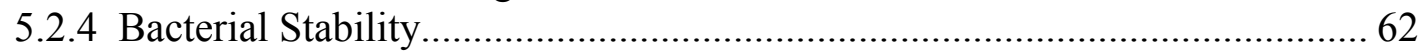

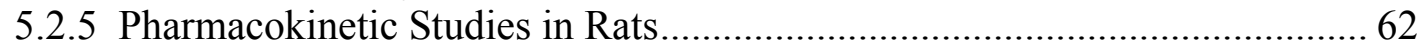

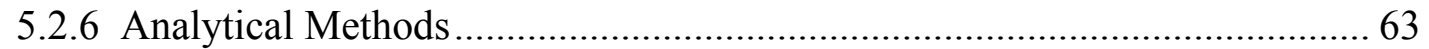

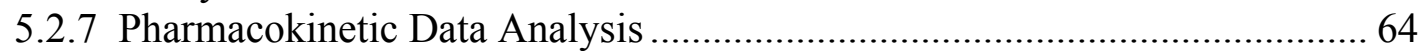

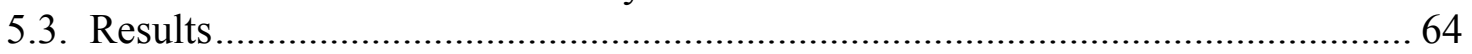

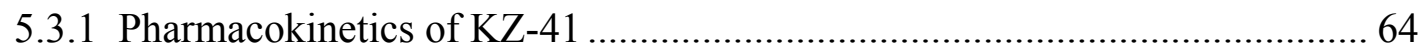

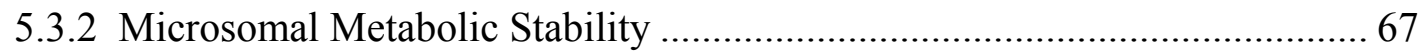

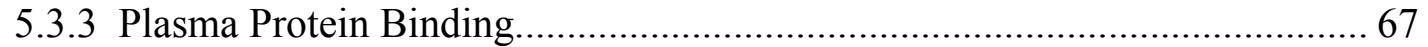

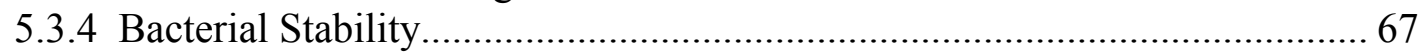

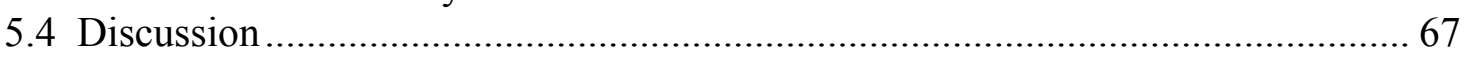

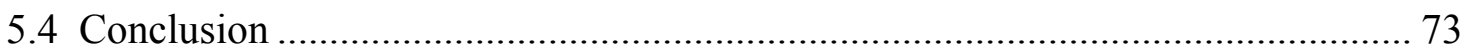

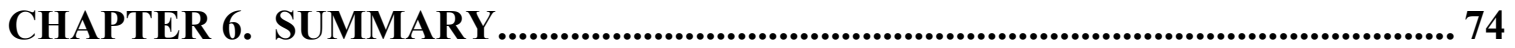

LIST OF REFERENCES .................................................................................. 76

VITA 


\section{LIST OF TABLES}

Table 2-1. Cytotoxicity test of quinic acid analogs on A549SN cell line by MTS method.

Table 4-1. Intra- and inter-day accuracy and precision of KZ-41 in rat plasma...............58

Table 5-1. Key pharmacokinetic parameters of KZ-41 in rats $(n=6)$ calculated by mean concentrations versus time profile (Dose: $10 \mathrm{mg} / \mathrm{kg}$ ).

Table 5-2. Key pharmacokinetic parameters of KZ-41 in rats by intravenous administration (Dose: $10 \mathrm{mg} / \mathrm{kg}$ ).

Table 5-3. Key pharmacokinetic parameters of KZ-41 in rats by oral administration (Dose: $10 \mathrm{mg} / \mathrm{kg}$ ).

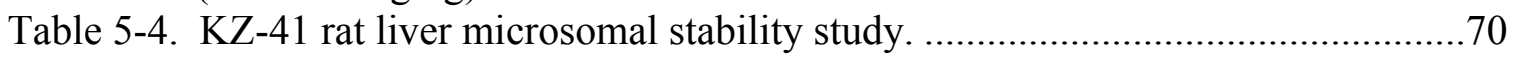

Table 5-5. KZ-41 protein binding in rat plasma. 


\section{LIST OF FIGURES}

Figure 1-1. Chemical structure of quinic acid and chlorogenic acid ..............................

Figure 1-2. QA biosynthesis and biodegradation cycle ...........................................2

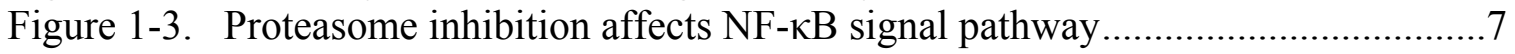

Figure 1-4. The general pathway of CGA metabolism by gut microflora in rat ..............9

Figure 1-5. Current trends in drug discovery............................................................11

Figure 1-6. NF- $\mathrm{kB}$ activity HTS System ................................................................. 13

Figure 2-1. NF- $\mathrm{NB}$ inhibition by QA and analogs using A549 cells stably transfected with a secreted alkaline phosphatase (SEAP) reporter..............18

Figure 2-2. Reaction kinetics of DPPH for determining antioxidant activity.................20

Figure 2-3. Rat paw edema percent volume change ...............................................22

Figure 3-1. NF-kB inhibition by KZ-41 derivatives using A549 cells stably transfected with a secreted alkaline phosphatase (SEAP) reporter...............38

Figure 3-2. Determining antioxidant activity by reaction kinetics of DPPH.................40

Figure 4-1. Chemical structure of quinic acid, KZ-41 and IS ....................................50

Figure 4-2. Representative HILIC-MS MRM chromatograms of KZ-41 and IS in extraction from rat plasma ...............................................................55

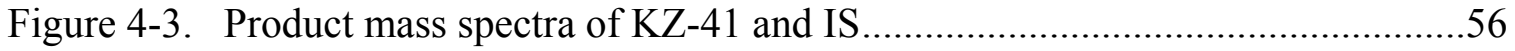

Figure 4-4. Representative standard curve of KZ-41 in rat plasma .............................57

Figure 5-1. Chemical structure of quinic acid amide KZ-41 ......................................65

Figure 5-2. Rat plasma meanlog concentration - time plot of KZ-41 after a single

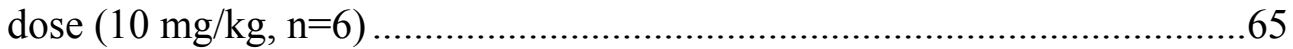

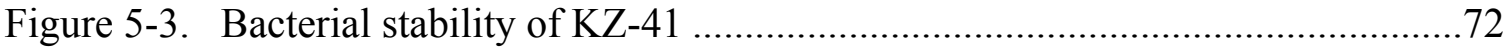




\section{LIST OF SCHEMES}

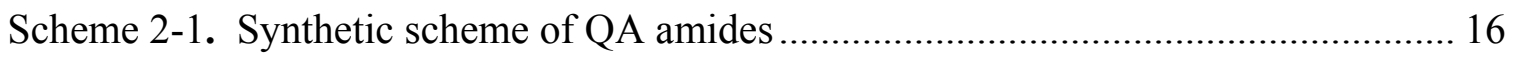

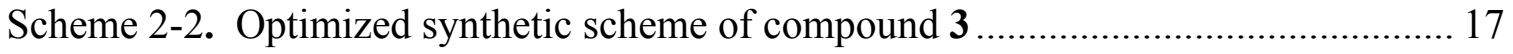

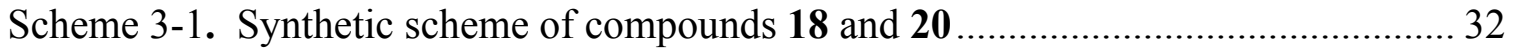

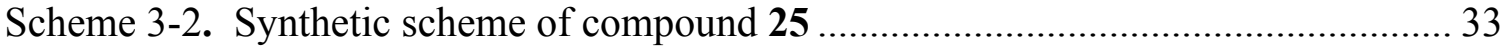

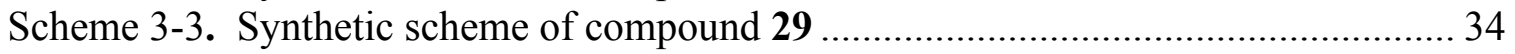

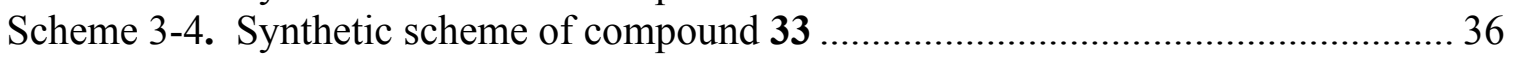

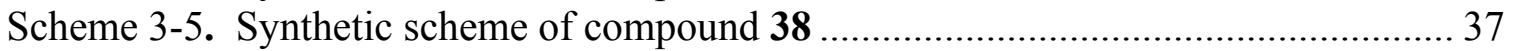




\section{LIST OF ABRREVIATIONS}

$\mathrm{ACN}$

AUC

CA

CGA

CL

$\mathrm{C}_{\max }$

$\mathrm{CV}$

DMSO

DPPH

DQD

ESI

$\mathrm{F}$

FDA

HILIC

HPLC

HTS

$\mathrm{IC}_{50}$

i.p.

i.v.

LC-MS

LLOQ

$\mathrm{MeOH}$

$\mathrm{mL}$

MRM

MS/MS

MW

NF- $\kappa B$

PMA

PTSA

QA

QDH

SA

S-ADME

SAR

SBDD

SEAP

TLC

TNF- $\alpha$

$\mathrm{Vz}$ acetonitrile

area under the plasma concentration-time curve

caffeic acid

chlorogenic acid

plasma clearance

maximum plasma concentration

coefficient of variation

dimethyl sulfoxide

diphenyl-1-picrylhydrazyl

3-dehydroquinate dehydratase

electrospray ionization

bioavailability

food and drug administration

hydrophilic interaction liquid chromatography

high performance liquid chromatography

High Throughput Screening

50 percent inhibition concentration

intra-peritoneally

intravenous

liquid chromatography-mass spectrometry

lower limit of quantitation

methanol

mil liter

multiple reaction monitor

tandem mass spectrometry

molecular weight

nuclear factor kappa B

phorbol myristate acetate

p-toluenesulfonic acid

quinic acid

quinate dehydrogenase

sinapic acid

structure - adsorption, distribution, metabolism, elimination

structure activity relationship

structure based drug discovery

secreted alkaline phosphatase

thin layer chromatography

tumor necrosis factor alpha

volume of distribution based on terminal phase 


\section{CHAPTER 1. INTRODUCTION}

The interest in development of natural products or modified natural products having anti-inflammatory activity has exploded in recent years. Recently, quinic acid (QA) and QA esters have been identified as active anti-inflammatory ingredients in hot water extracts of the herbal Uncaria tomentosa or Cat's claw (e.g., C-MED- $100^{\circledR}$ ),${ }^{1,2}$ and shown to enhance immune cell response and DNA repair in humans. ${ }^{3-5}$ This chapter will give an overview on the most recent studies on QA and its derivatives in the following fields, such as: biosynthesis and catabolism in nature, synthesis, biological activities, mechanisms of anti-inflammatory activity, etc.

\subsection{QA Structure and Its Derivatives}

QA, 1,3,4,5-Tetrahydroxy-cyclohexanecarboxylic acid (Figure 1-1), was first reported in $1790 .{ }^{6}$ The structure and the stereochemistry of QA were assigned in 1932 by H. O. L. Fisher and G. Dangschat. ${ }^{7}$ QA is a natural compound found widely in plants, ${ }^{8-10}$ such as in cinchona bark, particularly in South American barks; also largely in apple, peach, and rose tissue. ${ }^{11,12}$ Derivatives of QA, such as chlorogenic acid (CGA) (Figure 1-1), p-coumaryl quinate, etc., are also common in plants. ${ }^{13-15}$

\subsection{QA Biosynthesis and Catabolism}

\subsubsection{The QA Biosynthesis}

In nature, QA could be synthesized in one step from dehydroquinate by quinate dehydrogenase or from shikimate by quinate hydrolyase (Figure 1-2). ${ }^{16}$ Although the accumulation of QA appears to be restricted to specific plants, the occurrence of chlorogenate and its derivatives is more widespread. In higher plants, QA is the precursor for chlorogenate and may also serve as a storage or transport form of carbon. ${ }^{17}$ Chlorogenate is the major soluble phenylpropanoid in tobacco and a preformed protectant against fungal attack. ${ }^{18}$ It contributes to general plant health as part of a physical and

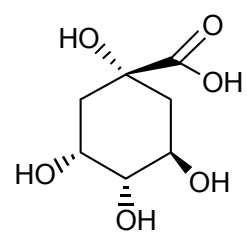

Quinic acid

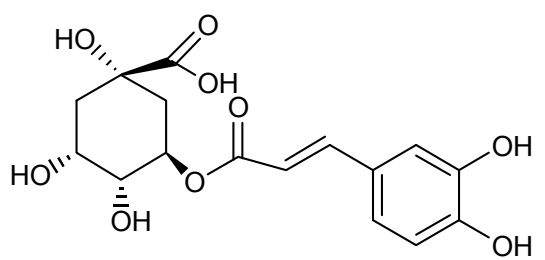

Chlorogenic acid

Figure 1-1. Chemical structure of quinic acid and chlorogenic acid. 


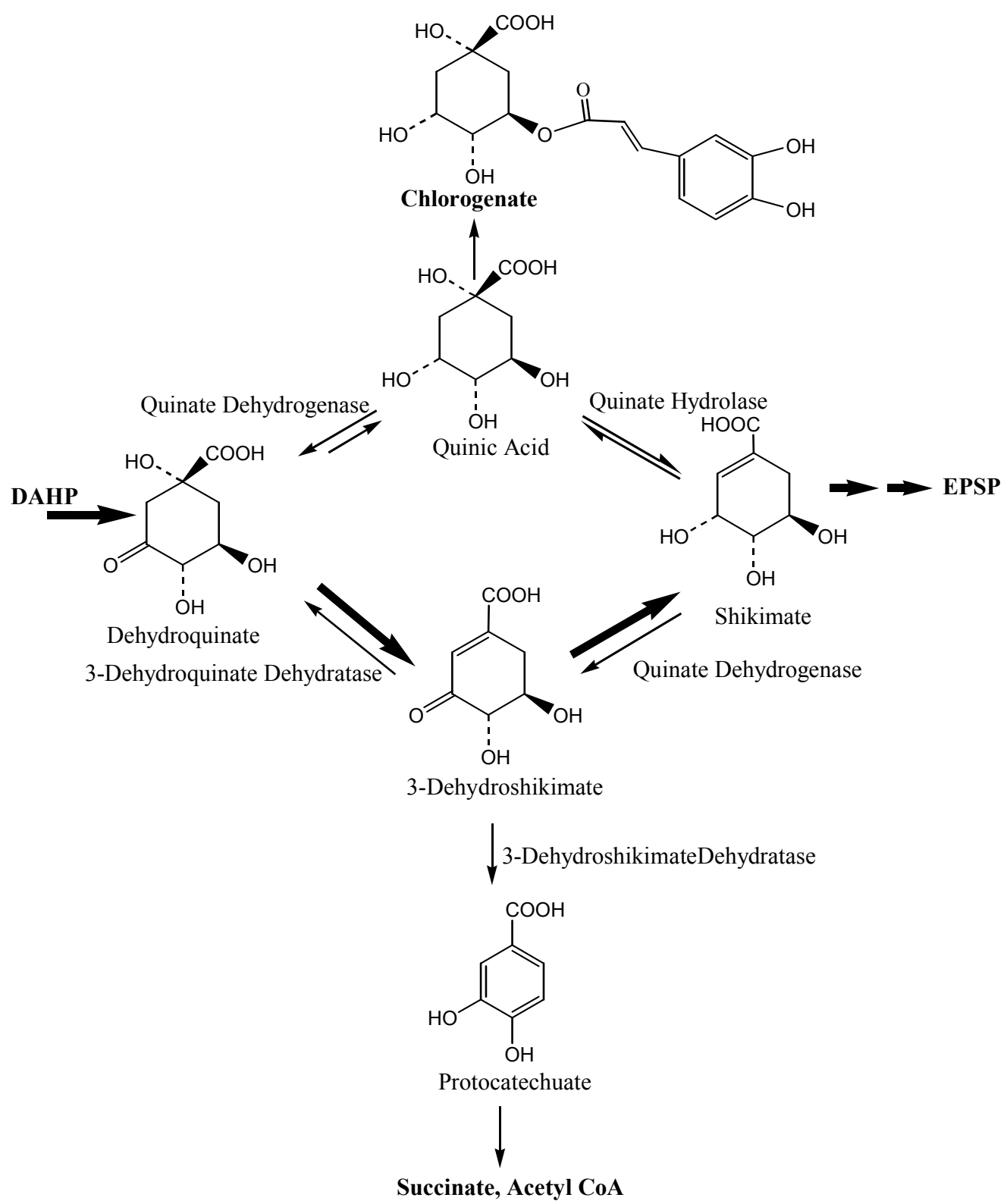

Figure 1-2. QA biosynthesis and biodegradation cycle. The cycle includes three intermediates of the shikimate pathway. DAHP: 3-deoxy-o-arabino-heptulosonate 7phosphate. EPSP: 5-enolpyruvylshikimate 3-phosphate. The enzymes of the QA cycle are (1) quinate (shikimate) dehydrogenase (QDH); (2) 3-dehydroquinate dehydratase (DQD); and (3) quinate hydrolyase. 3-Dehydroshikimate is aromatized to protocatechuate by Sdehydroshikimate dehydratase (4). Bold arrows indicate reactions of the main trunk of the shikimate pathway. 
possibly also a chemical barrier against microbial attack. Once this barrier is broken, the constituents become potential carbon sources for the attacker.

\subsubsection{The Shikimate Pathway}

The QA biosynthesis and biodegradation is through the shikimate pathway. In Figure 1-2, the bold arrows indicate reactions of the main trunk of the shikimate pathway. There are seven enzymes that catalyze the sequential steps of the shikimate pathway. The first reaction is catalyzed by 3-deoxy-D-arabino-heptulosonate 7-phosphate synthase (DAHP), phosphoenol pyruvate and erythrose-4-phosphate are reacted to form 3-deoxydarabino-heptulosonate 7-phosphate. The second to last reaction is catalyzed by 5enolpyruvylshikimate 3-phosphate synthase (EPSP), final to chorismate. The chorismate, the final product of the main trunk of the shikimate pathway, as a substrate for a number of anabolic sequences to primary and secondary compounds. These compounds include the aromatic amino acids phenylalanine, tyrosine, and tryptophan. ${ }^{19,20}$ The shikimate pathway has been found only in microorganisms and plants. Bacteria spend $>90 \%$ of their total metabolic energy on protein biosynthesis. Consequently, the bacterial shikimate pathway serves almost exclusively to synthesize the aromatic amino acids. ${ }^{21,22}$ Under normal growth conditions, $20 \%$ of the carbon fixed by plants flows through the shikimate pathway. ${ }^{23}$

\subsubsection{The QA Degradation}

QA has three biotransformation pathways (Figure 1-2). ${ }^{16}$ One is the biosynthesis of chlorogenate in plants. The other two pathways are in both microbe and plants. QA, along with shikimate, is readily degraded by fungi and some bacteria, first to protocatechuate and ultimately to succinate and acetyl- $\mathrm{C}_{\mathrm{O}} \mathrm{A}$. QA can also be degraded to shikimate, then follow the shikimate pathway to EPSP, and chorismate, and finally to aromatic amino acids phenylalanine, tyrosine, and tryptophan. ${ }^{19,20}$

\subsection{QA Degradation by Microorganisms}

One of the remarkable features of QA and shikimate pathway is the very different patterns of enzyme organization found in different species. ${ }^{24}$ In 1967, a QA oxidizing enzyme produced by acetic acid bacteria was discovered demonstrating that bacteria could catabolize QA. ${ }^{25}$ Subsequently, the QA catabolic pathway was described as a result of characterization of fungal mutants with lesions in genes encoding biosynthetic shikimate pathway enzymes. ${ }^{26} \mathrm{QA}$, along with shikimate, are degraded to form protocatechuate. The first three steps of QA catabolism are an NAD-dependent oxidation to form dehydroquinate, followed by two successive dehydrations to form dehydroshikimate and protocatechuate. The enzymes responsible for these conversions are quinate dehydrogenase (QDH), 3-dehydroquinate dehydratase (DQD), and 3dehydroshikimate dehydratase. Both QDH and DQD are located in the cytoplasmic 
membrane of bacteria. The QDH can also convert shikimic acid to dehydroshikimate. Bacteria and fungi utilize QA as a growth substrate and thus express an abundance of the aforementioned enzymes involved in QA degradation. High levels of QA catabolizing enzymes in gut bacteria is consistent with the finding that less than $10 \%$ of an orally administered dose QA is recovered in rats. ${ }^{27}$

One of the significant enzymes of QA degradation is QDH. QDH has been purified and characterized, and been extensively studied in fields such as catabolism and antibacterials. ${ }^{28,29}$ Adachi and coworkers reported QDH screening through several acetic acid bacteria and other bacteria. ${ }^{28,30}$ Strong enzyme activity was found in the membrane fraction of Gluconobacter melanogenus IFO 329, Gluconobacter oxydans IFO 3292, Gluconobacter oxydans IFO 3244, and some strains of Acinetobacter calcoaceticus. The following section describes the experimental procedure to prepare QDH enzyme from Gluconobacter oxydans.

Experiments involving G. oxydans was performed as described previously. ${ }^{31} G$. oxydans (ATCC, Manassas, VA) was cultured in basal media consisting of glycerol, 3 grams of yeast extract, and 1 gram of polypepton in 1 liter of tap water. In order to induce quinate dehydrogenase (QDH), quinate $(2 \mathrm{~g})$ was added and $\mathrm{pH}$ adjusted to 7.0. Microorganisms was grown in medium $(100 \mathrm{~mL})$ at $30^{\circ} \mathrm{C}$. For cell-mass production, a seed culture in $100 \mathrm{~mL}$ of medium was carried out overnight and transferred to 5 liters of fresh medium in a table top shaker incubator and cultivated for $12 \mathrm{hr}$ under aeration. Harvested cells were suspended in medium (5 mM potassium phosphate and $\mathrm{pH} 6.5)$ and centrifuged to pellet cells. Cells were stored without freezing.

Cell suspensions were prepared by homogenizing harvested cells at a ratio of $10 \mathrm{~g}$ of wet cells per $10 \mathrm{~mL}$ of $5 \mathrm{mM}$ potassium phosphate, $\mathrm{pH}$ 6.5. Cell suspsensions were passed twice through a French pressure cell press. Intact cells were removed by low speed centrifugation and the cell-free extract will be further centrifuged $(68,000 \mathrm{x} g$ for $90 \mathrm{~min}$ ) to separate the membrane and cytoplasmic soluble fraction. The membrane fraction was washed by homogenizing the precipitate in buffer and centrifugation repeated.

\subsection{Biological Activities of QA and Its Derivatives}

Uncaria tomentosa commonly known as Una de Gato or Cat's claw has been widely used historically as a natural remedy, and it is currently present in a number of nutritional formulations to treat a large variety of health disorders. ${ }^{32}$ Aqueous extracts from the bark or root bark of Cat's claw are used therapeutically in a diversity of diseases including allergy, arthritis, chemotherapy side effects, cancer, bacterial/fungal infections, gastrointestinal inflammation and gastric ulcers. ${ }^{33-37}$ The best known commercial preparations of Cat's claw are C-Med-100® and Activar AC-11 ${ }^{3} .{ }^{38-40}$ The active ingredients of C-MED-100® and Activar AC-11 ${ }^{\circledR}$ have been attributed to QA, and QA carboxy alkyl esters, such as CGA. ${ }^{1}$ Most recent studies have shown that CGA and QA have anti-hepatitis B virus activity, ${ }^{41}$ anti-obesity property, ${ }^{42}$ radio-protective effects ${ }^{43}$ 
and beneficial effects on cardiovascular diseases via suppressing P-selectin expression on platelets. ${ }^{44}$ In particular, such extracts have been found to have various anti-inflammatory effects such as inhibition of the production of the inflammatory cytokine TNF $\alpha$, scavenges free radicals ${ }^{45}$ and the activation of the central transcription factor nuclear factor $\kappa \mathrm{B}(\mathrm{NF}-\kappa \mathrm{B}){ }^{46-49}$ This factor regulates the expression of proinflammatory cytokines. ${ }^{50}$ In the following two section, we will discuss the anti-inflammatory and antioxidation properties of QA and its derivatives, and mechanism of action.

\subsubsection{The Anti-inflammatory Activity of QA and CGA through NF- $\kappa$ B Pathway}

$\mathrm{NF}-\kappa \mathrm{B}$ is made up of homodimeric and heterodimeric combinations of subunits which, prior to activation, are located in the cytoplasm bound to an inhibitor, I- $\kappa \mathrm{B}$. The biological system in which NF- $\kappa$ B plays the most important role is the immune system. There are many reviews available for this subject, such as Ghosh et al. in 2004 and $1998,{ }^{51,52} \mathrm{Li}$ and Verma in 2002, ${ }^{53}$ Bonizzi and Karin in 2004. ${ }^{54}$ Careful regulation of the transcriptional responses to many different stimuli is crucial to the proper functioning of the mammalian immune system. The genes regulated by NF- $\kappa \mathrm{B}$ include those controlling programmed cell death (apoptosis), cell survival, cell adhesion, proliferation, the innateand adaptive-immune responses, inflammation, the cellular-stress response and tissue remodeling. ${ }^{51,55-59}$ Although the maintenance of appropriate levels of NF- $\kappa \mathrm{B}$ activity is a critical factor in achieving normal cellular function, there are many potential applications of inhibition/interference of the NF- $\kappa \mathrm{B}$ signal pathway in the treatment of inflammatory disease and cancer. ${ }^{60-63}$ Calzado $^{63}$ has discussed NF- $\kappa$ B inhibitors used for the treatment of inflammation and cancer. Great efforts have been made for the development of highly specific NF- $\kappa B$ inhibitors, some of them being currently tested in phase II clinical trials.

Chlorogenic acid (3-caffeoyl-D-quinic acid; CGA) is an ester formed between caffeic acid (CA) and QA. CGA and other polyphenolic compounds found in fruits act as potent antioxidants. For example, CGA and CA are both capable of scavenging $\mathrm{NO}^{\circ},{ }^{64}$ a pro-inflammatory oxygen radical produced via the L-arginine pathway by infiltrating leucocytes. ${ }^{65}$ Interestingly, QA does not possess antioxidant activity suggesting alternative mechanisms underlie its anti-inflammatory activity. ${ }^{64}$ One potential mechanism involves inhibition of NF- $\kappa B$. Using Jurkat T cells transfected with an NF$\kappa \mathrm{B}$-dependent reporter gene, it was demonstrated that QA was able to inhibit PMA and ionomycin-induced $\mathrm{NF}-\kappa \mathrm{B}$ activity at concentrations that were neither cytotoxic nor inhibited proliferation. ${ }^{2}$ The ability of QA to prevent degradation of I $\mathrm{B}-\alpha$ was shown to be the mechanism by which it inhibited NF- $\kappa \mathrm{B}$ activity. Uniquely, QA did not affect the amount of phosphorylated I $\kappa$ B- $\alpha$. By comparison, the anti-oxidant pyrollidine dithiocarbamate inhibited the phosphorylation, breakdown, and re-synthesis of I $\kappa$ B- $\alpha$. The authors did not further investigate the mechanism(s) involved in QA's antiinflammatory potential. To our knowledge, proteasome inhibitors (e.g., bortezomib) are

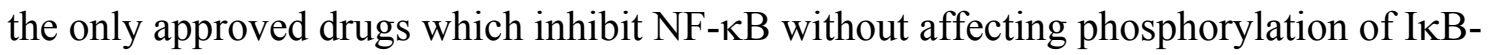
$\alpha$. Bortezomib binds to the chymotryptic site of the $20 \mathrm{~S}$ b-subunit, thereby blocking the proteasome. As a result I $\kappa \mathrm{B}$ will not be degraded into small peptides. It remains bound to the survival protein $N F-\kappa B$, thereby inhibiting $N F-\kappa B$ action. Inactive $N F-\kappa B$ will keep 
the inflammatory gene from transcription and translation to pro-inflammatory molecules, thus inhibiting inflammation. See Figure 1-3 from Vink et al. ${ }^{66}$

Recent work has demonstrated an interaction of QA derivatives with the carbohydrate binding proteins (lectins) involved in key leukocyte-endothelial cell interactions. $^{67,68}$ Tetrasaccharide sialyl Lewis x (sLex) ligands found on leukocytes contain sialic acid, L-fucose, and galactose which are essential for calcium-mediated binding of sLex to the carbohydrate binding proteins E, P, and L-selectin. Tetrasaccharide sLex exhibits a poor pharmacokinetic profile and thus cannot be developed as a selectin inhibitor. A search for druggable sLex mimetics led to the substitution of QA for fucose since the hydroxyl groups of QA mimic hydroxyl groups of fucose which make key interactions with protein side chains that bind calcium. ${ }^{67,68}$ Selective QA analogs were shown to decrease leukocyte rolling in response to LPS in an intravital microscopy mouse model and to decrease neutrophil influx in a murine thioglycollate-induced peritonitis model. ${ }^{68}$ Others have shown that selective QA analogs interact weakly with both P- and E-selectin using HL-60 cells. ${ }^{67}$

\subsubsection{The Antioxidant Effect of QA and CGA}

Antioxidant plays an important role in the prevention of human diseases. The oxidative damages happen when the reactive oxygen species, e.g. superoxide $\left(\mathrm{O}_{2}{ }^{\circ}\right)$ and hydroxyl $\left(\mathrm{HO}^{\circ}\right)$, attack the lipid in cell membranes, proteins and DNA to cause membrane injury and protein and DNA modification. ${ }^{69}$ QA has been confirmed as antioxidant, and extends its mode of action to include a basic nutritional benefit due to the enhanced metabolism of both tryptophan and nicotinamide. ${ }^{70}$ But QA was not showing its ability to trap free radicals by DPPH testing method. ${ }^{71}$ CGA and CA derivatives possess radical scavenging activity. The antioxidant effects of CGA and its derivatives might be due to three aspects: i) anti lipid-peroxidation; ii) radical scavenging; and iii) antioxidation of low density lipoprotein. ${ }^{72}$

\subsection{Bioavailability of QA and Its Derivatives}

Although QA and its derivatives showed much good biological activity, including anti-inflammatory activity; unfortunately, QA is utilized by gastrointestinal bacteria as a carbon source for aromatic acid synthesis. Consequently, only a small fraction of QA is absorbed after oral administration of QA. High levels of QA catabolizing enzymes in gut bacteria is consistent with the finding that less than $10 \%$ of an orally administered dose QA is recovered in rats. ${ }^{27}$ Our goal was to discover and develop stable QA derivatives as orally drugs, and to study the bioavailability of QA and its derivatives. 


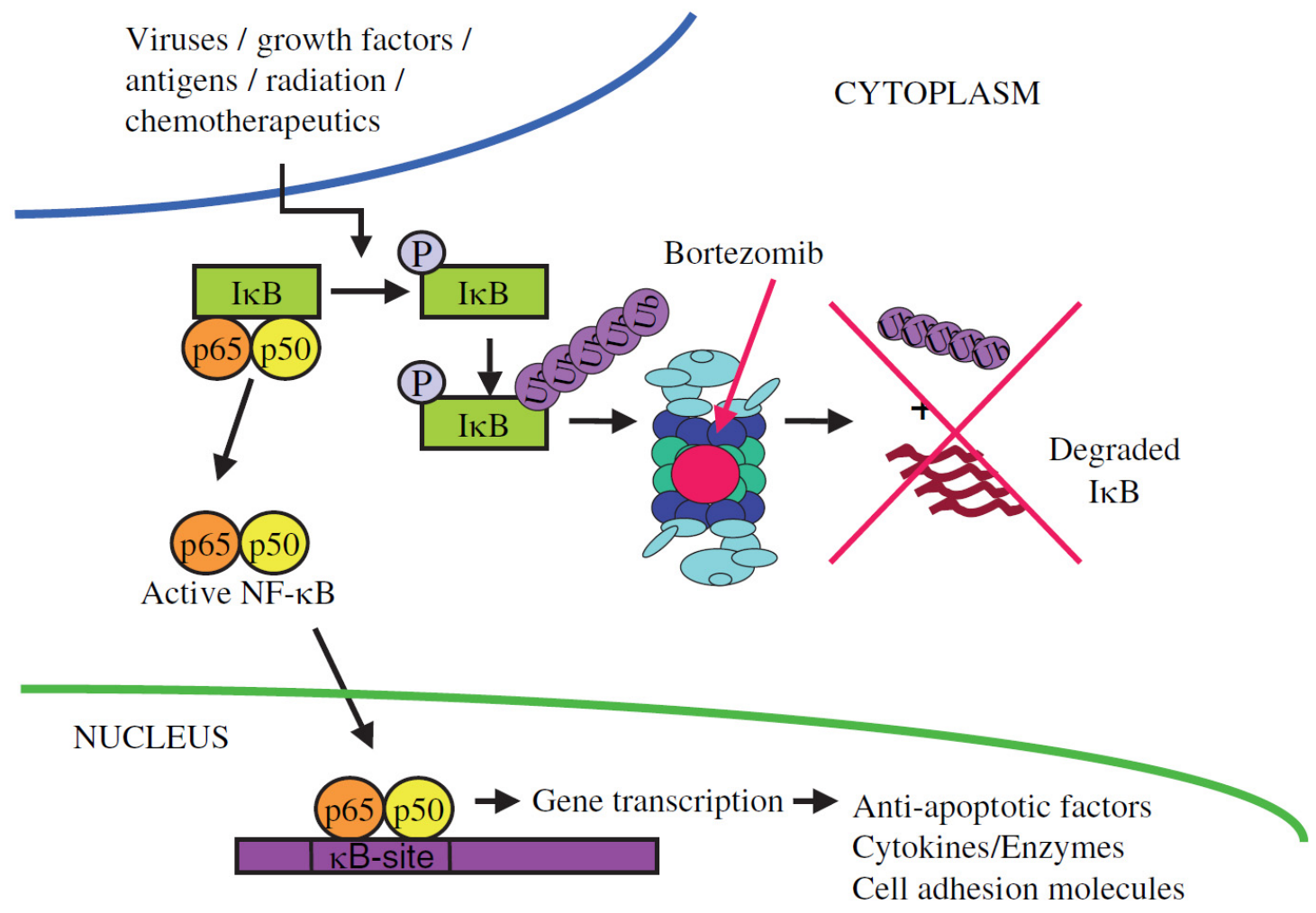

Figure 1-3. Proteasome inhibition affects NF- $\kappa B$ signal pathway. Bortezomib binds to the chymotryptic site of the $20 \mathrm{~S}$ b-subunit, thereby blocking the proteasome. As a result $\mathrm{I} \kappa \mathrm{B}$ will not be degraded into small peptides. It remains bound to the survival protein NF$\kappa \mathrm{B}$, thereby inhibiting NF- $\kappa \mathrm{B}$ action. Reprinted with permission. Vink, J.; Cloos, J.; Kaspers, G. J. Proteasome inhibition as novel treatment strategy in leukaemia. $\mathrm{Br} J$ Haematol 2006, 134, 253-62. 


\subsubsection{Bioavailability of CGA}

The bioavailability of CGA has been studied by several groups. ${ }^{73-76}$ Gonthier and coworkers have studied the bioavailability of CGA and compared it with that of CA and QA in rats fed diets supplemented with pure compounds for 8 days. ${ }^{73}$ They found that CGA poorly absorbed through the small intestine, largely reached the cecum of rats where it was hydrolyzed by the microflora, which exhibited esterase activities. ${ }^{77,78}$ Caffeic acid (CA) and QA were liberated and further metabolized. ${ }^{27,79}$ The proposed CGA metabolism pathway is shown in Figure 1-4. Some of the microbial metabolites still bearing a free phenolic group could act as antioxidants. ${ }^{80,81} \mathrm{~A}$ similar study has done by Azuma and coworkers in 2000, they found CGA was difficult to be absorbed from alimentary tract, although it could easily enter blood vessel after intraperitoneal injection. ${ }^{74}$ Unlike CGA, CA was absorbed through digestive tract. The bioavailability of CGA from green coffee extract in humans has also been studied. ${ }^{75}$ In this study, CGA was defined as phenolic compounds formed by the esterification of cinnamic acids, such as caffeic, ferulic, and p-coumaric acids, with QA. They were differentially absorbed and/or metabolized throughout the whole gastrointestinal tract.

\subsubsection{Bioavailability of QA}

Lautemann in 1863 showed that QA was excreted to a large extent as hippuric acid. $^{82}$ This has been confirmed by several authors, such as Quick in $1931 ;{ }^{83}$ Beer in $1951 ;{ }^{84}$ Cotran in $1960 .{ }^{85}$ Adamson in 1970 reported that the aromatization of QA was different between animal species, and gut bacteria played an important role in this process. $^{27}$ In man and some old world monkeys, oral quinic acid was extensively aromatized (20-60\%) and excreted in the urine as hippuric acid. The aromatization of oral quinic acid was considerably suppressed when gut flora were suppressed by neomycin. In the rat, only a small amount of hippuric acid was found in urine. QA was converted into benzoic acid by gut flora in all species (Figure 1-4). ${ }^{27,73,86}$ In summary, bioavailability of QA in animal is very low.

\subsection{Synthesis of QA and Its Derivatives}

QA total synthesis was reported by Grewe in $1954,{ }^{87}$ and another route was completed by Smissman in 1963. ${ }^{88}$ In 1964, Wolinsky developed a method to stereospecifically synthesize QA ${ }^{89}$ Recently, QA applications as a chiral template in natural product synthesis have been rapidly growing. This highly functionalized substrate was used to prepare natural compounds featuring cyclohexane substituted skeletons, and it has also extended to the preparation of open chain building blocks, which could be further transformed into optically active cyclopentane substituted skeletons and nitrogen containing targets. A review prepared by Barco has comprehensively covered QA chemistry literature up to the beginning of $1997 .{ }^{90}$ Many new chiral compounds have been synthesized based on inexpensive chiral material QA. More recently, there are many disease driven synthesis based on QA modification. Both Girard and Kaila have 


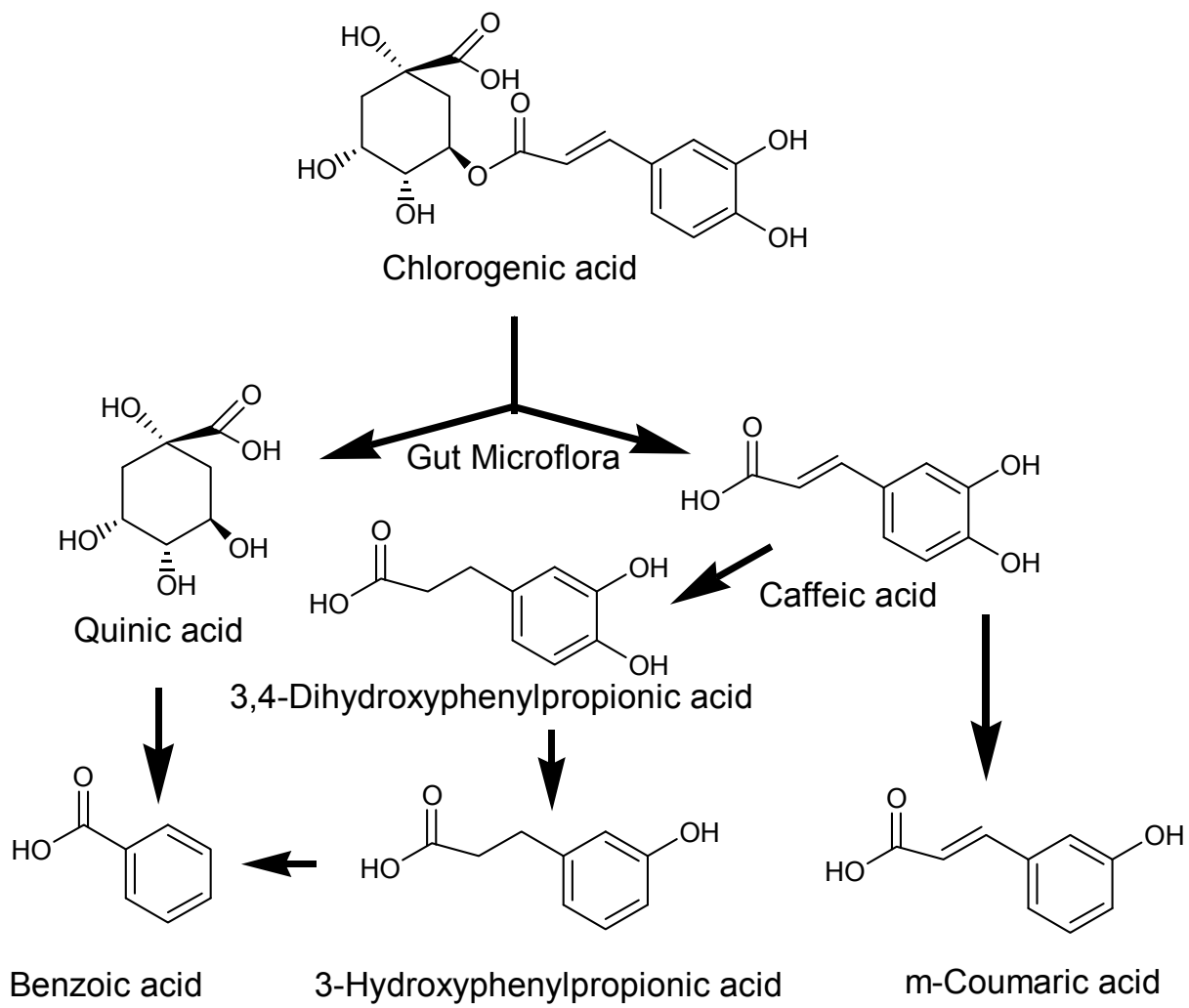

Figure 1-4. The general pathway of CGA metabolism by gut microflora in rat. First, the chlorogenic acid is degraded into QA and caffeic acid. 
synthesized QA derivatives as sialyl lewis $\mathrm{x}$-mimicking selectin inhibitors in order to target E-selectin. ${ }^{67,68}$ Kim made analogues as influenza neuraminidase inhibitors with potent anti-anfluenza activity. ${ }^{91}$ Sanchez-Sixto and Metaferia made compounds to kill Mycobacterium tuberculosis. ${ }^{92,93}$ Payne designed derivatives to act as type II dehydroquinase inhibitors. ${ }^{94}$ In 2001, Sefkow has synthesized CGA, 1-, 4-, and 5Caffeoylquinic Acid as antioxidant. ${ }^{95,96}$ Those esters have many other properties such as antibacterial, antimutagenic, antitumor, and antiviral. ${ }^{97}$ Metaferia synthesized QA derivatives macrolides that inhibit breast cancer cell migration in vitro. ${ }^{98}$ In summary, the interest in development of modified natural products based on QA is high in recent years.

\subsection{The Discovery of QA Derivatives as Oral Anti-inflammatory Agents}

In this study, we will follow the modern drug discovery procedure to discover and develop the QA derivatives, which possess orally active anti-inflammatory properties.

\subsubsection{Drug Discovery}

Drug discovery is very complicated, and is very important in human health, and plays an important role in science and technology. The Science magazine presented several special issues on this topic in 2000, 2004, and 2005. ${ }^{99-101}$ Driven by chemistry but increasingly guided by pharmacology and the clinical sciences, drug research has contributed more to the progress of medicine during the past century than any other scientific factor. The advent of molecular biology and, in particular, of genomic sciences is having a deep impact on drug discovery. ${ }^{102}$ In 2000 , Uppenbrink predicted that drug discovery is poised to revolutionized because of the soon-to-be-completed Human Genome Project, combinatorial chemistry, and other scientific advances. ${ }^{99}$ This made the introduction of target-based drug discovery, different from old physiology-based drug discovery. ${ }^{102-104}$ In physiology-based drug discovery, drug was tested with animal. But in target-based drug discovery, drug was tested with target. A target is usually a single gene, gene product or molecular mechanism that has been identified on the basis of genetic analysis or biological observations. ${ }^{105-107}$ After several years large increases in targetbased drug discovery R\&D investment, there has been a steady decline in the number of new molecules and biologicals that enter clinical development and finally reach the market. ${ }^{108,109}$ This perceived failure of current drug discovery has generated widespread concern, and several divergent opinions about the problem and its potential solutions. ${ }^{110}$ In 2008, Ho reported "Systems Biology: An Evolving Approach in Drug Discovery and Development."111 Butcher asked "Can cell systems biology rescue drug discovery?"110 Broadly defined, systems biology is the study of the interactions between components of a biological and how these integrate to produce a phenotype. This contrasts with the traditional approach that emphasized identification of the individual components of a system. ${ }^{111}$

No matter what strategies to take, there is a practical approach in drug discovery as shown in Figure 1-5. First, chemical compounds are made based on literature search, 


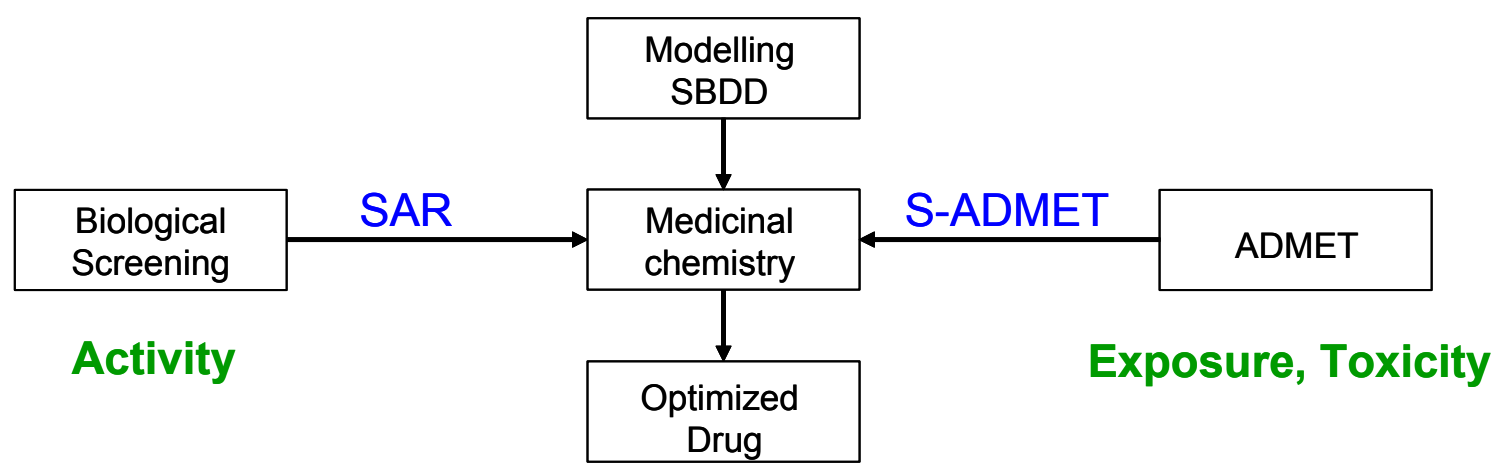

Figure 1-5. Current trends in drug discovery. SAR: Structure Activity Relationship; SADMET: Structure - Absorption, Distribution, Metabolism, Elimination, Toxicology; SBDD: Structure Based Drug Discovery.

natural products, or clinical observations. Then biological activity is tested by biological screening model. Structure activity relationship (SAR) is used to optimize the chemical structure. Lead compounds are further tested to optimize their biopharmaceutical, pharmacokinetic, and pharmacotoxic properties. That is structure - adsorption, distribution, metabolism, elimination, toxicology (S-ADMET) study. Computer model is also applied to assist structure based drug discovery (SBDD).

\subsubsection{The Study Goals and Hypothesis}

Our hypothesis states that it will be possible to convert QA into a derivative that will retain potent anti-inflammatory activity and be resistant to microbial degradation. This will ultimately provide orally active QA analogs. A major current concern with QA is the fact that it is significantly modified by intestinal bacteria that prevent it from showing good oral activity.

\subsubsection{Synthesis of $Q A$ amide analogs}

We initially focused on substitution at the carboxylic acid position, as previous work has shown that modifications of the carboxylic acid position modulated interaction of QA analogs with members of the selectin family (E- and P-selectin). ${ }^{67,68}$ These same authors showed that the presence of a carboxylic acid functional group was necessary for interaction with the selectins. ${ }^{67,68}$ A seriels of QA amides will be prepared, then go to biological screening against our NF- $\kappa$ B activity HTS System. QA amide leads will form a new template for anti-inflammatory agents. Further examination of the SAR and SADME will be conducted to optimize the leads. We hypothesize that further modifications to the amide series including substitution of the 3-alcholic functional group of QA will yield more potent analogs with enhanced resistance to microbial degradation. 


\subsubsection{Synthesis of dehydroquinate amide analogs}

We are also going to investigate to see if the $\mathrm{OHs}$ on the cyclohexane ring are needed for anti-inflammatory activity. We plan to investigate the importance of the hydroxyl groups on the cyclohexane ring by preparing the dehydroquinate amide analogs. We hypothesize these modifications will retain anti-inflammatory activity with enhanced resistance to microbial degradation. Because the first three steps of QA catabolism by bacteria are to form dehydroquinate, followed by two successive dehydrations to form dehydroshikimate and shikimate. ${ }^{16} \mathrm{We}$ assume the bacteria degradation will not take place when the new substrates lack of hydroxyl groups and/or having a double bond.

\subsubsection{Synthesis of $Q A$ amide ester analogs}

Based on the QA amide lead which serves as a new template for antiinflammatory agents, we are now planning to investigate to see if antioxidant groups are added for having both anti-inflammatory and antioxidant activity. We will prepare a serial of QA amide ester analogs with antioxidant groups such as caffeic acid, sinapic acid. We hypothesize these modifications will retain anti-inflammatory activity with additional antioxidant property. Furthermore, they will be hydrolyzed by the microflora, for an example, CGA is hydrolyzed into Caffeic acid and QA. ${ }^{77,78}$ Both caffeic acid and QA amide will not be consumed by gut bacteria, and easily be absorbed in animal digestive tract.

\subsubsection{QA derivatives anti-inflammatory activity}

Comprehensive SAR studies will identify those functional groups which further optimize activity and stability. Anti-inflammatory activity will be assessed using A549 cells containing an NF- $\mathrm{KB}$ secreted alkaline phosphatase reporter. To serve this purpose, we developed a cell-based high-throughput screening (HTS) system comprising A549 cells stably transfected with a plasmid containing a secreted alkaline phosphatase reporter gene driven by an NF- $\kappa \mathrm{B}$ response element (Figure 1-6). Upon TNF- $\alpha$ stimulation, NF$\kappa \mathrm{B}$ translocates to the nucleus and binds the $\kappa \mathrm{B}$ response element causing transcriptional activation. This activation drives production of the SEAP reporter, which can be measured in the cell culture supernatant as a surrogate marker for NF-kB activity. Cytotoxicity will be assessed using an MTS assay. Mechanistic studies and pre-clinical efficacy studies of our lead molecules in various inflammatory animal models are studied by other researchers, and will not be reported in this dissertation.

\subsubsection{Lead compounds S-ADME study}

Rapid degradation by gut flora potentially limits the oral effectiveness of current QA preparations. The resistance to microbial degradation of QA analog lead compound will be determined using bacterial Gluconobacter oxydans. Further biopharmaceutical 


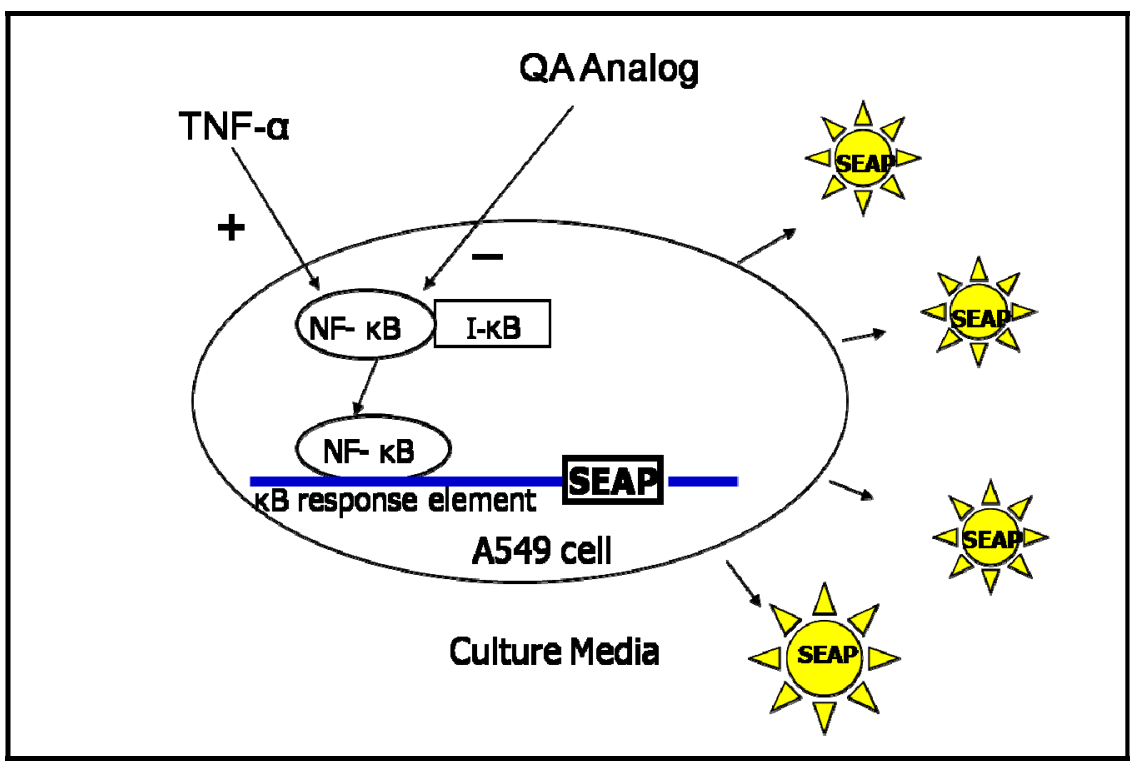

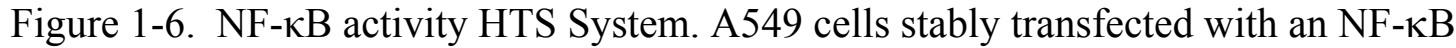
SEAP reporter were treated with TNF- $\alpha(10 \mathrm{ng} / \mathrm{mL})$ and QA analog $(1 \mu \mathrm{M})$ for 18 hours.

and pharmaceutics studies will also be done. These studies include microsomal stability, metabolite identification, plasma protein binding, pharmacokinetics and bioavailability in rat. In summary, The S-ADME study will investigate the bacterial stability, and absorption, distribution, metabolism and elimination of lead compounds in rat after intravenous and oral administration. 


\section{CHAPTER 2. SYNTHESIS AND BIOLOGICAL EVALUATION OF QUINIC ACID AMIDES*}

\subsection{Introduction}

The woody plant Uncaria is widely dispersed in tropical regions, including Southeast Asia, Africa, and South America. Uncaria genus plants have provided numerous structurally diverse medicinal natural products (e.g., alkaloids, terpenes, quinovic acid glycosides, flavonoids, and coumarins). ${ }^{112}$ The species with the most compounds identified $(\approx 50 ; 15$ of which are reported as novel) is the Peruvian Uncaria tomentosa commonly known as Uno de Gato or Cat's claw. Most commercial Cat's claw preparations are based on oxindole alkaloid content as alkaloids represent the most abundant class of compounds found in Uncaria. ${ }^{40}$

Hot water Cat's claw extracts (e.g., C-Med 100) have very low alkaloid content $(<0.5 \%)$ and yet retain significant immune enhancing activity. For example, the extract significantly accelerated recovery from doxorubicin-induced leukopenia in rats. ${ }^{38}$ Moreover, elevated leukocyte numbers were noted in humans, mice, and rats receiving repeat doses of the extract. ${ }^{3,113}$ Enhanced leukocyte counts correlated with prolonged lymphocyte survival, thus providing a potential mechanistic basis for the immune enhancing properties of the extract. ${ }^{113}$ Prolonged cell survival has been linked to enhanced DNA repair. ${ }^{3-5}$ Recently, quinic acid (QA) esters have been identified as biologically active components in the extract. ${ }^{1}$

The mechanism by which QA and its esters exert their anti-inflammatory activity is unclear, but appears to be related to inhibition of the pro-inflammatory transcription factor nuclear factor kappa B (NF- $\mathrm{B})$. For example, QA inhibited phorbol myristate acetate (PMA) and ionomycin-induced NF- $\kappa \mathrm{B}$ activation in Jurkat T cells at concentrations that neither induced cell death nor inhibited proliferation. ${ }^{2}$ Moreover, QA prevented degradation of the NF- $\kappa$ B inhibitor protein I $\kappa \mathrm{B}-\alpha$ without affecting levels of the phosphorylated I $\kappa \mathrm{B}-\alpha$ protein. ${ }^{2}$ Base hydrolysis of the extract dramatically reduces biological activity. For example, the lactone ester of QA (QAL) inhibits proliferation of mitogen-stimulated mouse lymphocytes, whereas QA does not affect proliferation. ${ }^{2}$ Further, base hydrolysis of the extract dramatically reduces its anti-proliferative effect against HL-60 and human mononuclear cells. ${ }^{1}$ Together, these data suggest the ester derivatives of QA found in the extract comprise a significant fraction of the biological activity.

QA is utilized by gastrointestinal bacteria as a carbon source for aromatic acid synthesis. Consequently, only a small fraction of QA is absorbed after oral administration of either QA or chlorogenic acid (CGA), which is a caffeic acid (CA)-containing ester of

*This chapter adapted with permission. Zeng, K.; Thompson, K.E.; Yates, C. R.; Miller, D. D. Synthesis and biological evaluation of quinic acid derivatives as anti-inflammatory agents. Bioorg Med Chem Lett, 2009, 19, 5458-60. 
QA. ${ }^{27}$ Our group has focused on the discovery and development of stable QA derivatives. Toward this end, we have identified water soluble amide analogs of QA $(1,3,4,5-$ tetrahydroxy-1-cyclohexanecarboxylic acid) which possess potent anti-inflammatory activity.

\subsection{Results and Discussion}

\subsubsection{Synthesis of Quinic Acid Amides}

Synthesis of the QA analogs was carried out using chemistry previously described. ${ }^{67,68,114}$ The synthesis of the lactone 2 was carried out using PTSA in refluxing benzene and DMF according to the procedure of Neelu Kaila et al. with minor revision. The lactone was then allowed to react with $\mathrm{N}$-propyl amine with acetic acid at $85^{\circ} \mathrm{C}$ and the resulting amide 3 was purified using flash chromatography. ${ }^{114}$ The amides 4-11, and 13 were formed by using different amines with lactone $\mathbf{2}$ in a manner similar to what was described for compound 3. QA, 1, was treated with acetic anhydride /pyridine to give compound 12. ${ }^{68}$ Each compound was characterized with Mass Spectroscopy, NMR, and elemental analysis. The general synthesis of QA analogs is shown in Scheme 2-1.

We found that the N-propyl amide derivative 3 had the greatest extent of NF- $\kappa \mathrm{B}$ inhibition following derivative in vitro A549 cells screening study. ${ }^{71}$ After that, compound 3 was moved up into in vivo study, such as animal biological activity and pharmacokinetics study. Large amount of compound $\mathbf{3}$ was needed. The above synthesis method used flash chromatography for purification in both steps. Compound $\mathbf{2}$ is very sticky on silica gel column, only about $4 \mathrm{~g}$ could be collected after each column. It is highly water soluble, can't be purified by liquid-liquid separation to remove PTSA. The optimized pathway to synthesis of amide 3 is shown in Scheme 2-2. The basic idea is to make intermediates less polar, so aqueous wash and separation are possible during compound purification. In Scheme 2-2, intermediate 14 was obtained in one step with high yield $(>80 \%),{ }^{115}$ it can be purified just by liquid-liquid separation followed by crystallization.

\subsubsection{Biology Test of Quinic Acid Amides}

The results of QA derivative anti-inflammatory high throughput screening are presented in Figure 2-1. The N-propyl amide derivative (3) was found to have the greatest extent of NF- $\kappa \mathrm{B}$ inhibition following derivative screening. We initially focused on substitution at the carboxylic acid position, as previous work has shown that QA ester derivatives have greater biological activity compared to QA. ${ }^{1,2}$ The carboxylic acid substituent appears critical to the interaction of QA derivatives with E- and P-selectin, key mediators of leukocyte endothelial cell interactions during inflammation. ${ }^{68}$ Interestingly, our most potent QA analog 3 demonstrates anti-inflammatory activity despite the fact that it lacks a carboxylic acid functional group. Further examination of 
<smiles>O=C(O)[C@@]1(O)CC(O)[C@@H](O)[C@H](O)C1</smiles><smiles>CC(=O)O[C@H]1C[C@](OC(C)C)(C(=O)O)C[C@H](OC(C)=O)[C@@H]1OC(C)=O</smiles>

12

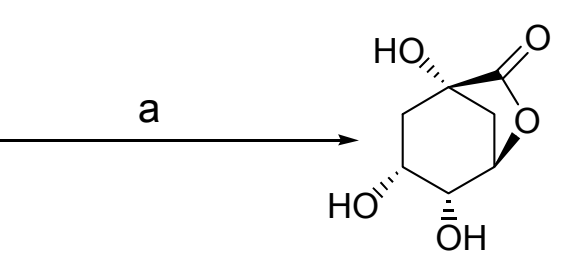

2

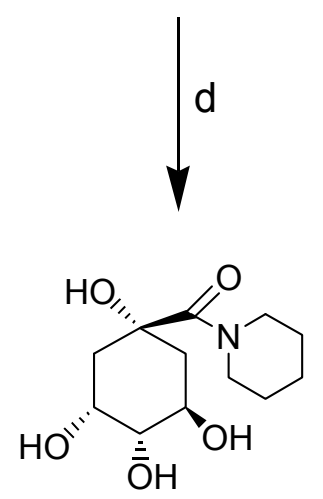

11

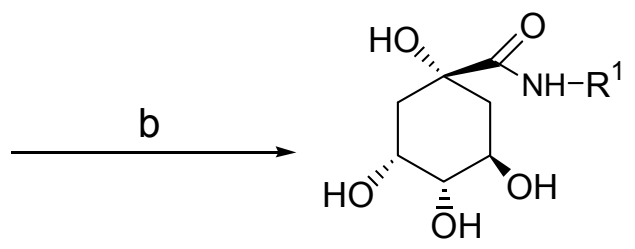

3: $\mathrm{R}^{1}=-\mathrm{C}_{3} \mathrm{H}_{7}$, 13: $\mathrm{R}^{1}=<$

4: $\mathrm{R}^{1}=-\mathrm{C}_{12} \mathrm{H}_{25}$

5: $\mathrm{R}^{1}=-\mathrm{C}_{16} \mathrm{H}_{33}$

6: $\mathrm{R}^{1}=\longrightarrow$

7: $\mathrm{R}^{1}=\square$

8: $\mathrm{R}^{1}=$

9: $\mathrm{R}^{1}=ح_{\mathrm{O}}^{\mathrm{N}} \prod_{-}^{\mathrm{O}}$

10: $\mathrm{R}^{1}=ح \mathrm{NH}_{2}$

Scheme 2-1. Synthetic scheme of QA amides. Reagents and conditions: (a) PTSA, DMF, C6H6, Dean-Stark, reflux, 78\%; (b) R1-NH2, AcOH, oil bath $85^{\circ} \mathrm{C}$; (c) (Ac)2O; (d) R$\mathrm{NH} 2, \mathrm{AcOH}$, oil bath $85^{\circ} \mathrm{C}$. 


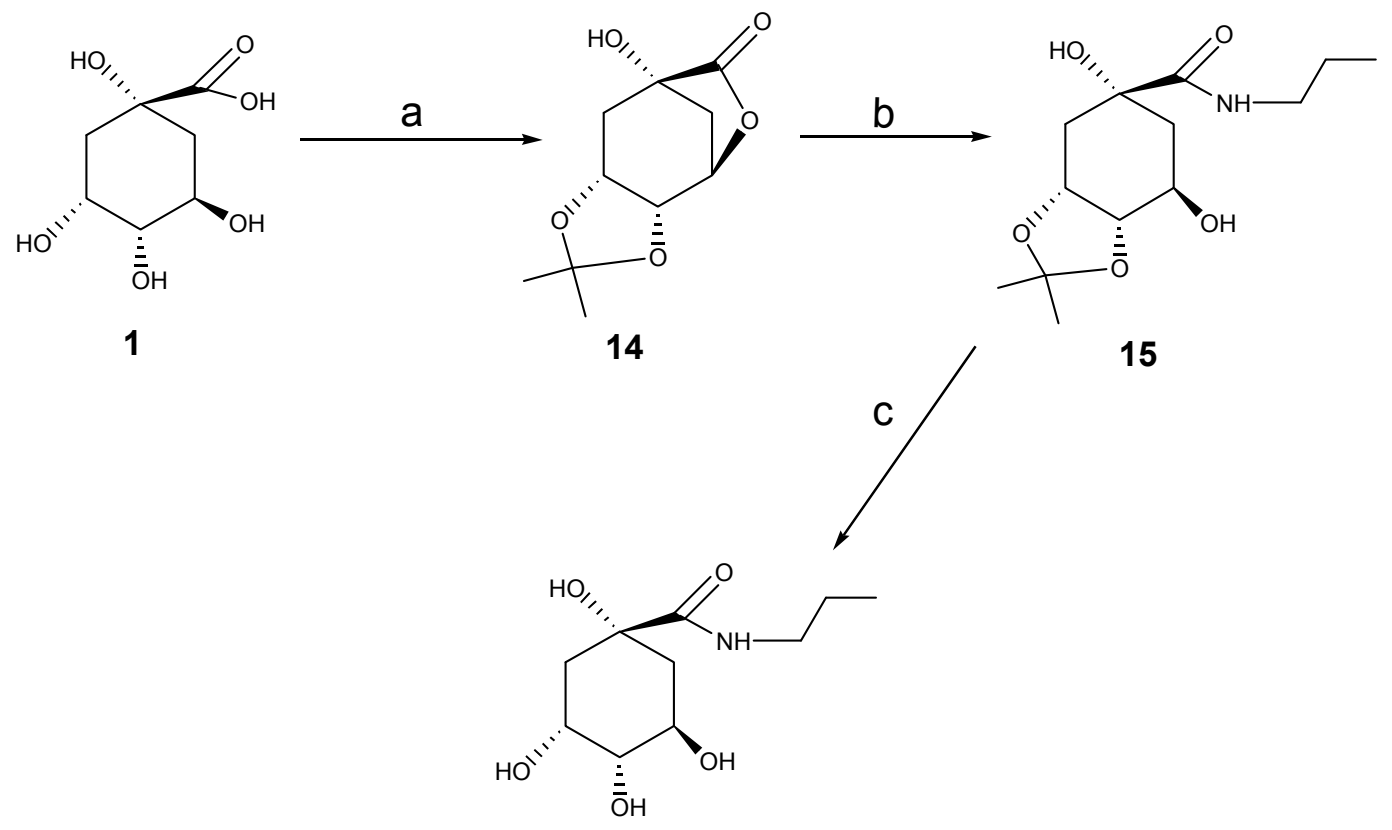

$3 a$

Scheme 2-2. Optimized synthetic scheme of compound 3. Reagents and conditions: (a) PTSA, 2,2-DMP, Acetone, reflux, $80 \%$; (b) $\mathrm{C}_{3} \mathrm{H}_{7}-\mathrm{NH}_{2}$, AcOH, oil bath $85^{\circ} \mathrm{C}$; (c) $1 \mathrm{~N}$ $\mathrm{HCl}$. 


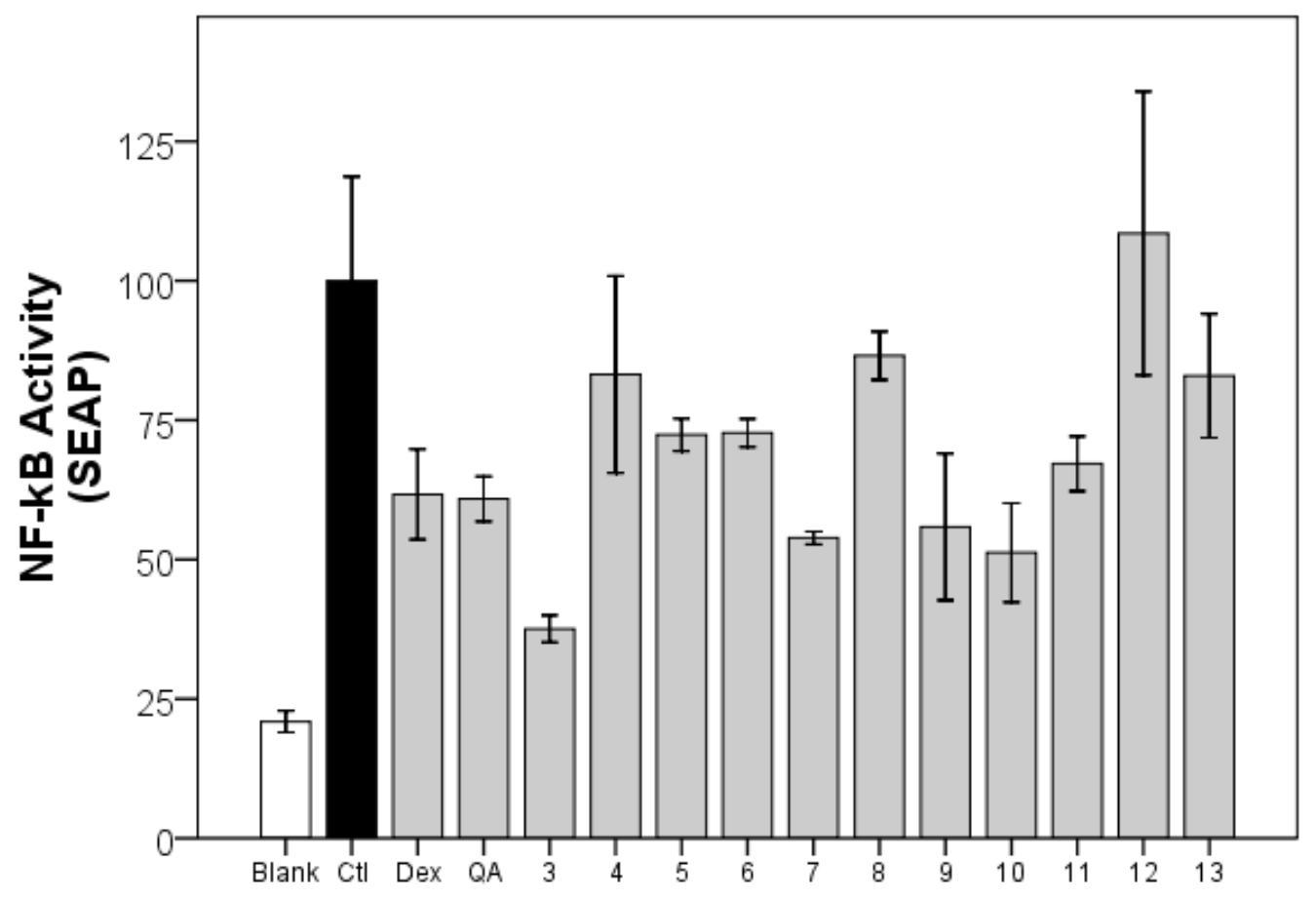

Error Bars: +/- $1 \mathrm{SD}$

Figure 2-1. NF- $\kappa$ B inhibition by QA and analogs using A549 cells stably transfected with a secreted alkaline phosphatase (SEAP) reporter. NF- $\kappa$ B activity was measured 18 hours after addition of TNF- $\alpha(10 \mathrm{ng} / \mathrm{mL})$ and either QA or synthesized derivatives (3-13; $1 \mu \mathrm{M})$. Dexamethasone (Dex; $1 \mu \mathrm{M})$ was used as a positive control. Data are presented as percent (\%) inhibition relative to control (ctl; TNF- $\alpha$ alone) and represent $\%$ mean inhibition \pm standard deviation $(\mathrm{n}=3)$. Blank: media only. 
the SAR demonstrated that acetylation of the hydroxyl groups, which yields compound 12, leads to reduced NF- $\mathrm{B}$ inhibitory activity. A variety of modifications to the amide substitution of $\mathbf{3}$ were tolerated, e.g., 9, 10 and 13, a N-isopropyl amide, but no substitution was better than the N-propyl amide. The NF- $\mathrm{KB}$ inhibitory potency $\left(\mathrm{IC}_{50}\right)$ of our most active analog 3 was determined as $2.83 \pm 1.76 \mu \mathrm{M}$.

Next, we determined the anti-oxidant potential of QA derivatives using the 2, 2diphenyl-1-picrylhydrazyl (DPPH) free radical scavenging method. ${ }^{116}$ The dietary polyphenol CGA, an ester of QA and CA, possesses potent anti-oxidant activity, which is attributed to the presence of CA. We thus compared the anti-oxidant potential of CGA, CA, QA and 3 to determine if the anti-inflammatory activity of QA and $\mathbf{3}$ was attributable to anti-oxidant activity. Ascorbic acid 6-palmitate was included as a structurally-distinct molecule with described anti-oxidant activity. As expected, Figure 2-2 demonstrates the anti-oxidant activity of CGA, CA, and ascorbic acid. However, QA and $\mathbf{3}$ have no such anti-oxidant activity. The fact that QA does not possess anti-oxidant activity is consistent with a previous report. ${ }^{64}$ Therefore, the NF- $\kappa \mathrm{B}$ inhibitory activity of QA derivatives is attributed to mechanisms unrelated to anti-oxidant activity.

QA esters potently inhibit proliferation of mitogen-stimulated mouse lymphocytes without increasing cytotoxicity. ${ }^{2}$ We thus determined the anti-proliferative potential of QA and 3 against A549 cells using the MTS assay. Neither QA nor 3 exhibited cytotoxic activity toward A549 cells at concentrations up to $100 \mu \mathrm{M}$ (Table 2-1). Thus, it appears that inhibition of NF- $\kappa \mathrm{B}$ by QA and $\mathbf{3}$ is related not to anti-proliferative or cytotoxic activity, but rather to a yet to be determined mechanism.

Figure 2-3 shows the activities of drugs in carrageenan induced paw edema animal model. Positive control dexamethasone significantly reduced the volume of swelled rat paw. QA and $\mathbf{3}$ had not demonstrated significantly effect on reducing paw edema volume. Therefore, the anti-inflammatory activity of QA derivatives is attributed to mechanisms different from carrageenan induced paw edema.

\subsection{Conclusions}

We have synthesized novel QA analogs that potently inhibit NF- $\kappa \mathrm{B}$ activity in TNF- $\alpha$-stimulated human alveolar Type II-like epithelial cells (A549). We have demonstrated that the QA analogs presented in this work do not exert their activity via anti-oxidant, cytotoxic, or carrageenan induced paw edema mechanisms. Mechanistic studies and pre-clinical efficacy studies of our lead molecule $\mathbf{3}$ in various inflammatory animal models are on-going. 


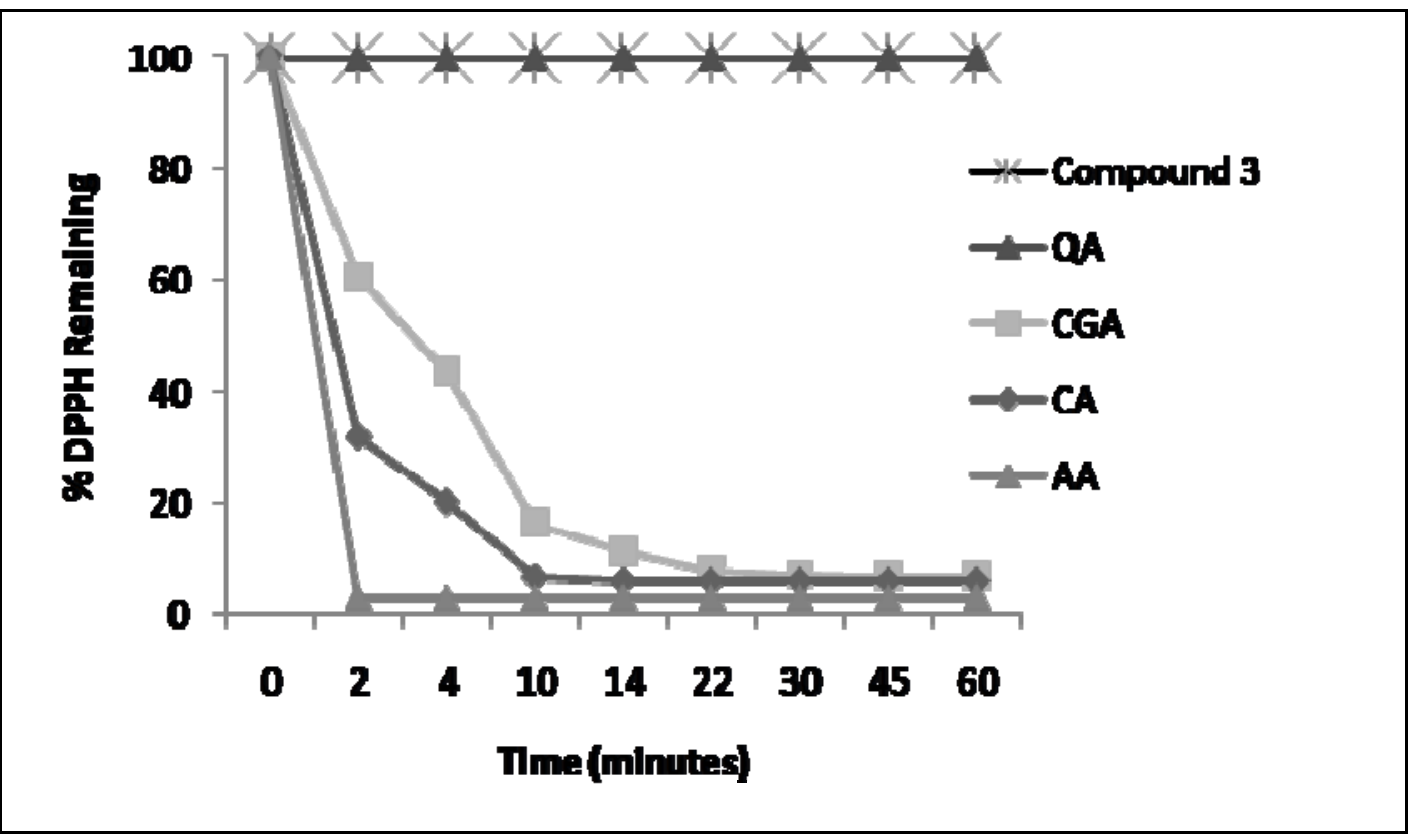

Figure 2-2. Reaction kinetics of DPPH for determining antioxidant activity. Caffeic acid (CA), chlorogenic acid (CGA), ascorbic acid (AA), QA and Compound $\mathbf{3}$ were prepared in $50 \%$ acetone. The conventional colorimetric DPPH scavenging capacity was determined by UV absorption measured at $515 \mathrm{~nm}$. CA, CGA and AA showed strong anti-oxidant activity, while QA and $\mathbf{3}$ had no anti-oxidant activity. 
Table 2-1. Cytotoxicity test of quinic acid analogs on A549SN cell line by MTS method.

\begin{tabular}{|c|c|c|}
\hline Compound name & $\mathrm{R}_{1}$ structure & A549SN cell viability $(C=100 \mu \mathrm{M})$ \\
\hline 4 & $-\mathrm{C}_{12} \mathrm{H}_{25}$ & no observed toxicity \\
\hline 5 & $-\mathrm{C}_{16} \mathrm{H}_{33}$ & no observed toxicity \\
\hline 6 & & no observed toxicity \\
\hline 7 & & no observed toxicity \\
\hline 3 & $-\mathrm{C}_{3} \mathrm{H}_{7}$ & no observed toxicity \\
\hline 8 & & no observed toxicity \\
\hline 11 & & no observed toxicity \\
\hline 9 & C & no observed toxicity \\
\hline 10 & & no observed toxicity \\
\hline 2 & & no observed toxicity \\
\hline 12 & & no observed toxicity \\
\hline QA & di & no observed toxicity \\
\hline
\end{tabular}




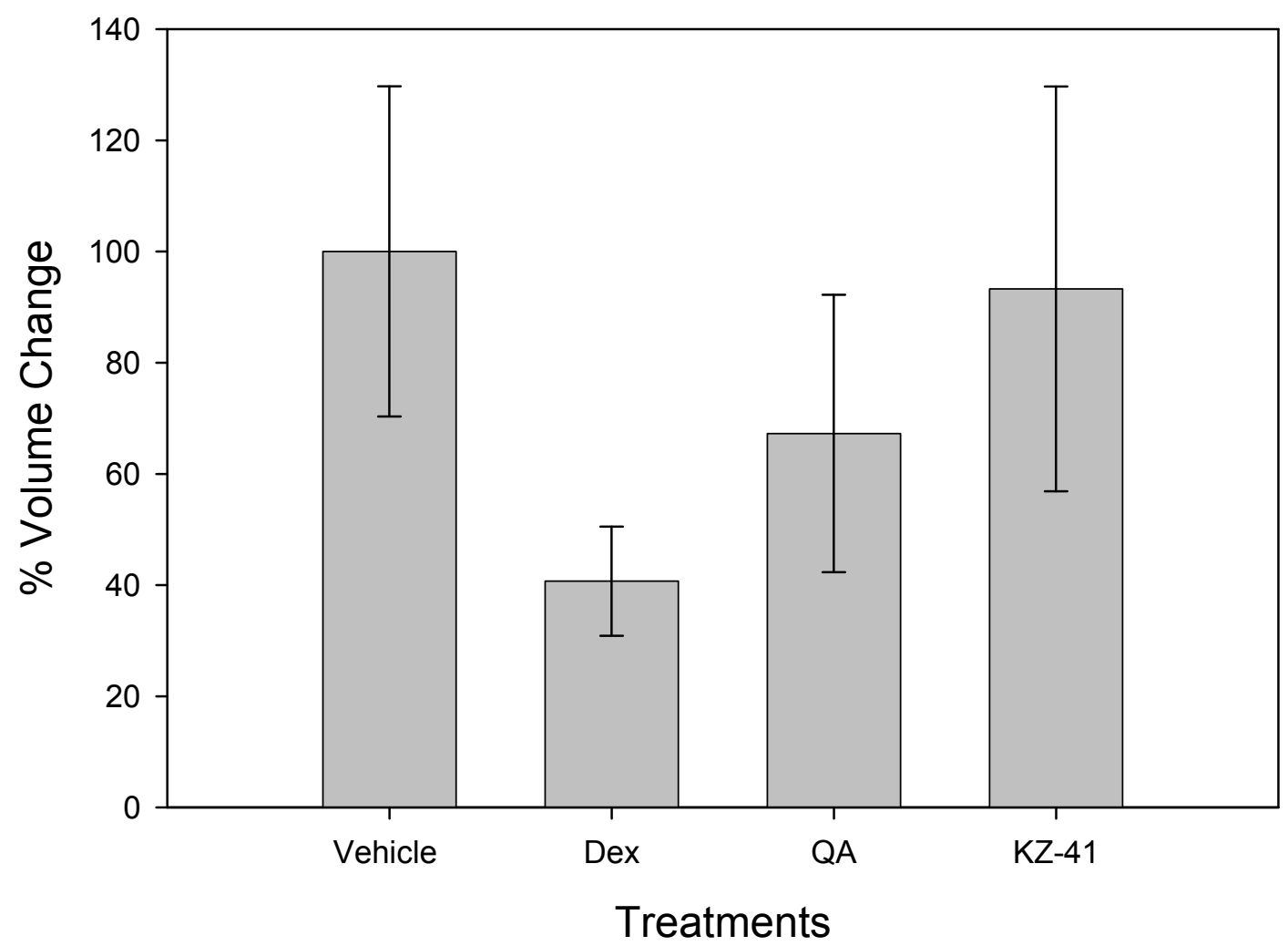

Figure 2-3. Rat paw edema percent volume change. (Normalized to Vehicle) $(n=6)$. Treatment $(50 \mathrm{mg} / \mathrm{kg})$ and $1 \%$ Carrageenan $(10 \mathrm{mg} / \mathrm{kg})$. 


\subsection{Experimental}

\subsubsection{Chemistry}

All reagents and solvents were purchased from Sigma Aldrich Chemical Co. (St. Louis, MO), Fischer Scientific (Pittsburgh, PA), and TCI (Portland, OR), and were used without any further purification. Thin layer chromatography (TLC) was performed on silica gel chromatogram plates purchased from Analtech, Inc. Flash chromatography was performed either on silica gel (60 $\AA, 200-425$ mesh) or on pre-packed silica gel columns by using a Horizon HPFC system (Biotage, Charlottesville, VA). Molecular masses were collected with electron spray ionization mass spectra (ESI-MS) on a Bruker/Hewlett Packard Esquire LC/MS instrument. Nuclear magnetic resonance (NMR) spectra for ${ }^{1} \mathrm{H}$ NMR and ${ }^{13} \mathrm{C}$ NMR were recorded on a Bruker ARX 300 instrument and/or a Varian Inova-500 MHz instrument. The chemical shifts value $(\delta)$ are reported in parts per million (ppm) relative to tetramethylsilane (TMS), and coupling constants (J) were reported in hertz. Peaks are abbreviated as were indicated as follows: s, singlet; d, doublet; $\mathrm{t}$, triplet; $\mathrm{m}$, multiplet. Deuterated solvents were purchased from Cambridge Isotope Laboratories, Inc. Melting points were determined on a Fisher-Johns melting point apparatus and are uncorrected. Elemental analyses $(\mathrm{C}, \mathrm{H}, \mathrm{N})$ were performed by Atlantic Microlab Inc. (Norcross, GA), and are accepted within \pm 0.4 of the theoretical values. High performance liquid chromatography (HPLC) separation was performed on a Hewlett Packard LC instrument with model 1100 system.

The following is the general procedure for the synthesis of quinic acid amides. The synthesis of the lactone 2 was carried out using PTSA in refluxing benzene and DMF according to the procedure of Neelu Kaila et al. with minor revision. The lactone was then allowed to react with $\mathrm{N}$-propyl amine with acetic acid at $85^{\circ} \mathrm{C}$ and the resulting amide 3 was purified using flash chromatography. ${ }^{114}$ The amides 4-11, and $\mathbf{1 3}$ were formed by using different amines with lactone 2 in a manner similar to what was described for compound 3. QA, 1, was treated with acetic anhydride/pyridine to give compound 12. ${ }^{68}$ Each compound was characterized with Mass Spectroscopy, NMR, and elemental analysis. The general synthesis of QA analogs is shown in Scheme 2-1.

1,3,4-Trihydroxy-6-oxa-bicyclo[3.2.1]octan-7-one (2). In a $200 \mathrm{~mL}$ roundbottom flask fitted with a stirring bar, reflux condenser, Dean-Stark trap, and argon inlet, $5 \mathrm{~g}$ of quinic acid $(\mathbf{1}, 26 \mathrm{mmol})$ was placed and $10 \mathrm{~mL}$ of dry DMF was added via syringe and the slurry stirred at room temperature. Next, benzene $60 \mathrm{~mL}$ and p-toluenesulfonic acid $0.5 \mathrm{~g}$ were added, and the slurry was heated to reflux for $26 \mathrm{~h}$. Check TLC to confirm the completion of reaction. A 1:1 mixture of EtOAc and heptane $(100 \mathrm{~mL})$ was added to the cooled reaction mixture. The mixture was stirred for $1 \mathrm{hr}$ at room temperature and filtered. The collected solid was again stirred with a 1:1 mixture of EtOAc and heptane $(100 \mathrm{~mL})$ for $1 \mathrm{hr}$ at room temperature and filtered. Tituration was repeated one more time with a 1:1 mixture of EtOAc and heptane $(100 \mathrm{~mL})$ and the precipitate collected to give $3.5 \mathrm{~g}$ of Lactone 2 (78\% yield). mp: $192-193^{\circ} \mathrm{C}, \mathrm{R}_{\mathrm{f}} 0.25$ (EtOAc); MS: [M-H] : 171; ${ }^{1} \mathrm{H}$ NMR (300 MHz, DMSO) $\delta 1.72(\mathrm{t}, \mathrm{J}=1.6 \mathrm{~Hz}, 1 \mathrm{H}), 1.82-1.88(\mathrm{~m}, 1 \mathrm{H}), 2.07-2.13(\mathrm{~m}$, 
1H), 2.25 (d, J=1.1 Hz, 1H), 3.49 (ddd, J=11.4, 6.3, $5.7 \mathrm{~Hz}, 1 \mathrm{H}), 3.82$ (t, J=4.5 Hz, 1H), $4.61(\mathrm{t}, \mathrm{J}=5.1 \mathrm{~Hz}, 1 \mathrm{H}), 4.816(\mathrm{~d}, \mathrm{~J}=6.0 \mathrm{~Hz}, 1 \mathrm{H}), 5.23$ (d, J=4.5 Hz, 1H), 5.89 (s, 1H). Anal. $\left(\mathrm{C}_{7} \mathrm{H}_{10} \mathrm{O}_{5}\right)$ calculated: $\mathrm{C}, 48.28 ; \mathrm{H}, 5.79$. Found: C, 48.38; H, 5.76.

1,3,4,5-tetrahydroxy-cyclohexane-carboxylic acid propylamide (3). In a 50 $\mathrm{mL}$ round-bottom flask fitted with a stirring bar, reflux condenser, $0.196 \mathrm{~g}$ Lactone 2 ( $1.125 \mathrm{mmol})$, and propylamine $(0.83 \mathrm{~mL}, 0.6 \mathrm{~g}, 10.13 \mathrm{mmol})$ were combined, then glacial acetic acid $(0.19 \mathrm{~mL}, 0.20 \mathrm{~g}, 3.36 \mathrm{mmol})$ was added. The solution was warmed to $85^{\circ} \mathrm{C}$ in oil bath for $30 \mathrm{~min}$, at which time TLC $\left(\mathrm{CHCl}_{3}: \mathrm{MeOH}: \mathrm{NH}_{3} \mathrm{OH}=100: 10: 1\right)$ indicated complete consumption of the starting lactone. Reaction mixture was purified by flash column with same solvent as TLC. Collect product 3, 206mg (80\% yield). mp: 132$133^{\circ} \mathrm{C}, \mathrm{R}_{\mathrm{f}} 0.03\left(\mathrm{CHCl}_{3}: \mathrm{MeOH}: \mathrm{NH}_{3} \mathrm{OH}=100: 10: 1\right)$; MS: [M-H] ${ }^{-=} 232 ;{ }^{1} \mathrm{H}$ NMR $(300$ MHz, DMSO) $\delta 0.81(\mathrm{t}, \mathrm{J}=6.0 \mathrm{~Hz}, 3 \mathrm{H}), 1.41(\mathrm{ddd}, \mathrm{J}=13.8,7.5,6.9 \mathrm{~Hz}, 2 \mathrm{H}) 1.66-1.83(\mathrm{~m}$, 4H), $3.02(\mathrm{dd}, \mathrm{J}=6.9,6.6 \mathrm{~Hz}, 2 \mathrm{H}), 3.22(\mathrm{t}, \mathrm{J}=6.0 \mathrm{~Hz}, 1 \mathrm{H}), 3.75$ (ddd, J=13.8, 9.0, $5.7 \mathrm{~Hz}$, 1H), $3.94(\mathrm{~s}, 1 \mathrm{H}), 4.69(\mathrm{~d}, \mathrm{~J}=4.5 \mathrm{~Hz}, 1 \mathrm{H}), 4.90(\mathrm{~d}, \mathrm{~J}=5.4 \mathrm{~Hz}, 1 \mathrm{H}), 5.19(\mathrm{~d}, \mathrm{~J}=3.6 \mathrm{~Hz}, 1 \mathrm{H})$, $5.47(\mathrm{~s}, 1 \mathrm{H}), 7.76(\mathrm{t}, \mathrm{J}=5.4 \mathrm{~Hz}, 1 \mathrm{H})$. Anal. $\left(\mathrm{C}_{10} \mathrm{H}_{19} \mathrm{NO}_{5}\right)$ calculated: $\mathrm{C}, 51.49 ; \mathrm{H}, 8.21 ; \mathrm{N}$, 6.00. Found: C, 51.57; H, 8.40; N, 6.01.

1,3,4,5-Tetrahydroxy-cyclohexanecarboxylic acid dodecylamide (4). In a 50 $\mathrm{mL}$ round-bottom flask fitted with a stirring bar, reflux condenser, $0.12 \mathrm{~g}$ Lactone 2 $(0.706 \mathrm{mmol})$, and dodecylamine $(1.19 \mathrm{~g}, 6.42 \mathrm{mmol})$ were combined, then glacial acetic acid $(0.13 \mathrm{~mL}, 2.20 \mathrm{mmol})$ was added. The solution was warmed to $85^{\circ} \mathrm{C}$ in oil bath for 30 min, at which time TLC (EtOAc) indicated complete consumption of the starting lactone. Reaction mixture was purified by flash column with same solvent as TLC. Collect product 4, $34 \mathrm{mg}$. Rf 0.15 (EtOAc); MS: [M-H $]^{-}=258 ;{ }^{1} \mathrm{H}$ NMR $(300 \mathrm{MHz}$, DMSO) $0.85(\mathrm{t}, \mathrm{J}=6.0 \mathrm{~Hz}, 3 \mathrm{H}), 1.20-1.41(20 \mathrm{H}) 1.66-1.83(\mathrm{~m}, 4 \mathrm{H}), 3.02(\mathrm{dd}, \mathrm{J}=6.9,6.6$ $\mathrm{Hz}, 2 \mathrm{H}), 3.22$ (t, J=6.0 Hz, 1H), 3.75 (ddd, J=13.8, 9.0, $5.7 \mathrm{~Hz}, 1 \mathrm{H}), 3.94$ (s, 1H), 4.69 (d, $\mathrm{J}=4.5 \mathrm{~Hz}, 1 \mathrm{H}), 4.90(\mathrm{~d}, \mathrm{~J}=5.4 \mathrm{~Hz}, 1 \mathrm{H}), 5.19(\mathrm{~d}, \mathrm{~J}=3.9 \mathrm{~Hz}, 1 \mathrm{H}), 5.47(\mathrm{~s}, 1 \mathrm{H}), 7.76(\mathrm{t}$, $\mathrm{J}=5.4 \mathrm{~Hz}, 1 \mathrm{H})$.

1,3,4,5-Tetrahydroxy-cyclohexanecarboxylic acid hexadecylamide (5). In a $50 \mathrm{~mL}$ round-bottom flask fitted with a stirring bar, reflux condenser, $0.23 \mathrm{~g}$ Lactone 2 $(1.34 \mathrm{mmol})$, and hexadecylamine $(2.91 \mathrm{~g}, 12.04 \mathrm{mmol})$ were combined, then glacial acetic acid $(0.24 \mathrm{~mL}, 4.01 \mathrm{mmol})$ was added. The solution was warmed to $85^{\circ} \mathrm{C}$ in oil bath for 60 min under argon, at which time TLC (EtOAc: $\mathrm{MeOH}=20: 1$ ) indicated complete consumption of the starting lactone. Reaction mixture was purified by flash column with same solvent as TLC. Collect product 5, $54 \mathrm{mg}$. Rf 0.05 (EtOAc: $\mathrm{MeOH}=20: 1)$; MS: [M-H] $]^{-}=414 ;{ }^{1} \mathrm{H}$ NMR (300 MHz, DMSO) 0.85 (t, J=6.0 Hz, 3H), $1.20-1.41(28 \mathrm{H}) 1.66-1.83(\mathrm{~m}, 4 \mathrm{H}), 3.02(\mathrm{dd}, \mathrm{J}=6.9,6.6 \mathrm{~Hz}, 2 \mathrm{H}), 3.22(\mathrm{t}, \mathrm{J}=6.0 \mathrm{~Hz}, 1 \mathrm{H})$, 3.75 (ddd, J=13.8, 9.0, $5.7 \mathrm{~Hz}, 1 \mathrm{H}), 3.94$ (s, 1H), 4.69 (d, J=4.5 Hz, 1H), 4.90 (d, J=5.4 $\mathrm{Hz}, 1 \mathrm{H}), 5.19(\mathrm{~d}, \mathrm{~J}=3.9 \mathrm{~Hz}, 1 \mathrm{H}), 5.47(\mathrm{~s}, 1 \mathrm{H}), 7.76(\mathrm{t}, \mathrm{J}=5.4 \mathrm{~Hz}, 1 \mathrm{H})$. Anal. $\left(\mathrm{C}_{23} \mathrm{H}_{45} \mathrm{NO}_{5}\right)$ calculated: C, 66.47; H, 10.91; N, 3.37. Found: C, 66.04; H, 10.91; N, 3.37.

1,3,4,5-Tetrahydroxy-cyclohexanecarboxylic acid benzylamide (6). In a 50 $\mathrm{mL}$ round-bottom flask fitted with a stirring bar, reflux condenser, $0.23 \mathrm{~g}$ Lactone 2 (1.34 $\mathrm{mmol})$, and benzylamine $(1.27 \mathrm{~g}, 11.70 \mathrm{mmol})$ were combined, then glacial acetic acid 
$(0.23 \mathrm{~mL}, 3.90 \mathrm{mmol})$ was added. The solution was warmed to $85^{\circ} \mathrm{C}$ in oil bath for 45 min under argon, at which time TLC $\left(\mathrm{CHCl}_{3}: \mathrm{MeOH}: \mathrm{NH}_{3} \mathrm{OH}=100: 10: 1\right)$ indicated complete consumption of the starting lactone. Reaction mixture was purified by flash column with same solvent as TLC. Collect product 6, $210 \mathrm{mg}$ (80\% yield). Rf 0.15 $\left(\mathrm{CHCl}_{3}: \mathrm{MeOH}: \mathrm{NH}_{3} \mathrm{OH}=100: 10: 1\right)$; MS: $[\mathrm{M}-\mathrm{H}]^{-}=280 ;{ }^{1} \mathrm{H}$ NMR (300 MHz, DMSO) 1.66-1.87 (m, 4H), $3.02(\mathrm{dd}, \mathrm{J}=6.9,6.6 \mathrm{~Hz}, 2 \mathrm{H}), 3.22$ (t, J=6.0 Hz, 1H), 3.75 (ddd, $\mathrm{J}=13.8,9.0,5.7 \mathrm{~Hz}, 1 \mathrm{H}), 3.96(\mathrm{~s}, 1 \mathrm{H}), 4.27(\mathrm{~d}, \mathrm{~J}=6.0 \mathrm{~Hz}, 1 \mathrm{H}), 4.69(\mathrm{~d}, \mathrm{~J}=4.5 \mathrm{~Hz}, 1 \mathrm{H})$, $4.90(\mathrm{~d}, \mathrm{~J}=5.4 \mathrm{~Hz}, 1 \mathrm{H}), 5.22(\mathrm{~d}, \mathrm{~J}=3.6 \mathrm{~Hz}, 1 \mathrm{H}), 5.53(\mathrm{~s}, 1 \mathrm{H}), 7.72-7.74(\mathrm{~m}, 5 \mathrm{H}), 8.32$ (t, $\mathrm{J}=6.0 \mathrm{~Hz}, 1 \mathrm{H})$. Anal. $\left(\mathrm{C}_{14} \mathrm{H}_{19} \mathrm{NO}_{5}\right)$ calculated: $\mathrm{C}, 59.78 ; \mathrm{H}, 6.81 ; \mathrm{N}, 4.98$. Found: $\mathrm{C}$, $59.65 ; \mathrm{H}, 6.77 ; \mathrm{N}, 4.89$.

1,3,4,5-Tetrahydroxy-cyclohexanecarboxylic acid cyclohexylamide (7). In a $50 \mathrm{~mL}$ round-bottom flask fitted with a stirring bar, reflux condenser, $0.20 \mathrm{~g}$ Lactone 2 $(1.15 \mathrm{mmol})$, and cyclohexylamine $(1.18 \mathrm{~mL}, 1.03 \mathrm{~g}, 10.34 \mathrm{mmol})$ were combined, then glacial acetic acid $(0.23 \mathrm{~mL}, 3.90 \mathrm{mmol})$ was added. The solution was warmed to $85^{\circ} \mathrm{C}$ in oil bath for 90 min under argon, at which time TLC $\left(\mathrm{CHCl}_{3}: \mathrm{MeOH}: \mathrm{NH}_{3} \mathrm{OH}=100: 10: 1\right)$ indicated complete consumption of the starting lactone. Reaction mixture was purified by flash column with same solvent as TLC. Collect product 7, $75 \mathrm{mg}$ ( $25 \%$ yield). Rf 0.05 $\left(\mathrm{CHCl}_{3}: \mathrm{MeOH}: \mathrm{NH}_{3} \mathrm{OH}=100: 10: 1\right) ; \mathrm{MS}:[\mathrm{M}-\mathrm{H}]^{-}=272 ;{ }^{1} \mathrm{H}$ NMR (300 MHz, DMSO) 1.15-1.40 (m, 5H), $1.50-1.80(\mathrm{~m}, 8 \mathrm{H}), 3.22(\mathrm{ddd}, \mathrm{J}=13.8,9.0,5.7 \mathrm{~Hz}, 1 \mathrm{H}), 3.50(\mathrm{~d}, 1 \mathrm{H})$, $3.70-3.80(\mathrm{~m}, 1 \mathrm{H}), 3.93(\mathrm{~d}, 1 \mathrm{H}), 4.68(\mathrm{~d}, \mathrm{~J}=4.5 \mathrm{~Hz}, 1 \mathrm{H}), 4.87(\mathrm{~d}, \mathrm{~J}=6.0 \mathrm{~Hz}, 1 \mathrm{H}), 5.18(\mathrm{~d}$, $\mathrm{J}=3.9 \mathrm{~Hz}, 1 \mathrm{H}), 5.50(\mathrm{~s}, 1 \mathrm{H}), 7.40(\mathrm{~d}, \mathrm{~J}=8.4 \mathrm{~Hz}, 1 \mathrm{H})$. Anal. $\left(\mathrm{C}_{13} \mathrm{H}_{23} \mathrm{NO}_{5}\right)$ calculated: $\mathrm{C}$, 57.13; H, 8.48; N, 5.12. Found: C, 57.13; H, 8.48; N, 4.49 .

1,3,4,5-Tetrahydroxy-cyclohexanecarboxylic acid phenylamide (8). In a 50 $\mathrm{mL}$ round-bottom flask fitted with a stirring bar, reflux condenser, $0.23 \mathrm{~g}$ Lactone 2 (1.34 $\mathrm{mmol})$, and phenylamine $(1.11 \mathrm{~mL}, 1.13 \mathrm{~g}, 12.15 \mathrm{mmol})$ were combined, then glacial acetic acid $(0.24 \mathrm{~mL}, 4.40 \mathrm{mmol})$ was added. The solution was warmed to $85^{\circ} \mathrm{C}$ in oil bath for 120 min under argon, at which time TLC $\left(\mathrm{CHCl}_{3}: \mathrm{MeOH}: \mathrm{NH}_{3} \mathrm{OH}=100: 10: 1\right)$ indicated complete consumption of the starting lactone. Reaction mixture was purified by flash column with same solvent as TLC. Collect product 8, $38 \mathrm{mg}$ (10.1\% yield). Rf 0.05 $\left(\mathrm{CHCl}_{3}: \mathrm{MeOH}: \mathrm{NH}_{3} \mathrm{OH}=100: 10: 1\right) ; \mathrm{MS}:[\mathrm{M}-\mathrm{H}]^{-}=266 ;{ }^{1} \mathrm{H}$ NMR (300 MHz, DMSO) $1.84-1.95(\mathrm{~m}, 4 \mathrm{H}), 3.24-3.32(\mathrm{~m}, 1 \mathrm{H}) 3.80-3.86(\mathrm{~m}, 1 \mathrm{H}), 4.04(\mathrm{~d}, \mathrm{~J}=4.5 \mathrm{~Hz}, 1 \mathrm{H}), 4.73$ - $4.76(\mathrm{~m}, 2 \mathrm{H}), 5.35(\mathrm{~d}, \mathrm{~J}=3.9 \mathrm{~Hz}, 1 \mathrm{H}), 5.76(\mathrm{~s}, 1 \mathrm{H}), 7.06(\mathrm{t}, \mathrm{J}=7.5 \mathrm{~Hz}, 1 \mathrm{H}), 7.29$ (t, J=7.5 $\mathrm{Hz}, 2 \mathrm{H}), 7.70(\mathrm{t}, \mathrm{J}=7.5 \mathrm{~Hz}, 2 \mathrm{H}), 9.50(\mathrm{~s}, 1 \mathrm{H})$. Anal. $\left(\mathrm{C}_{13} \mathrm{H}_{17} \mathrm{NO}_{5} .0 .5 \mathrm{H}_{2} \mathrm{O}\right)$ calculated: $\mathrm{C}$, 56.51; H, 6.57; N, 5.07. Found: C, 56.80; H, 6.48; N, 4.72.

2-[(1,3,4,5-Tetrahydroxy-cyclohexanecarbonyl)-amino]-ethyl-carbamic acid tert-butyl ester (9). In a $50 \mathrm{~mL}$ round-bottom flask fitted with a stirring bar, reflux condenser, $0.14 \mathrm{~g}$ Lactone $2(0.82 \mathrm{mmol})$, and (2-Amino-ethyl)-carbamic acid tert-butyl ester $(1.07 \mathrm{~g}, 6.24 \mathrm{mmol})$ were combined, then glacial acetic acid $(0.13 \mathrm{~mL}, 2.10 \mathrm{mmol})$ was added. The solution was warmed to $85^{\circ} \mathrm{C}$ in oil bath for 180 min under argon, at which time TLC $\left(\mathrm{CHCl}_{3}: \mathrm{MeOH}: \mathrm{NH}_{3} \mathrm{OH}=100: 10: 1\right)$ indicated complete consumption of the starting lactone. Reaction mixture was purified by flash column with same solvent as TLC. Collect product 9, $270 \mathrm{mg}$ (97\% yield). Rf $0.05\left(\mathrm{CHCl}_{3}: \mathrm{MeOH}: \mathrm{NH}_{3} \mathrm{OH}\right.$ $=100: 10: 1)$; MS: $[\mathrm{M}+\mathrm{Na}]^{+}=357 ;{ }^{1} \mathrm{H}$ NMR (300 MHz, DMSO) 1.38 (s, 9H), $1.78-1.82$ 
(m, 4H), $3.00(\mathrm{~d}, \mathrm{~J}=3 \mathrm{~Hz}, 2 \mathrm{H}), 3.10(\mathrm{~d}, \mathrm{~J}=3 \mathrm{~Hz}, 2 \mathrm{H}), 3.19$ - 3.32 (m, 1H) 3.72 - 3.94 (m, 1H), 3.94 (d, J=4.5 Hz, 1H), 4.69 (d, J=4.8 Hz, 1H), 4.82 (d, J=6.0 Hz, 1H), 5.21 (d, $\mathrm{J}=4.2 \mathrm{~Hz}, 1 \mathrm{H}), 5.45(\mathrm{~s}, 1 \mathrm{H}), 6.82(\mathrm{t}, \mathrm{J}=5.4 \mathrm{~Hz}, 2 \mathrm{H}), 7.82(\mathrm{t}, \mathrm{J}=6.0 \mathrm{~Hz}, 1 \mathrm{H})$. Anal. $\left(\mathrm{C}_{14} \mathrm{H}_{26} \mathrm{~N}_{2} \mathrm{O}_{7} .0 .33 \mathrm{H}_{2} \mathrm{O}\right)$ calculated: $\mathrm{C}, 49.40 ; \mathrm{H}, 7.90 ; \mathrm{N}, 8.23$. Found: $\mathrm{C}, 49.56 ; \mathrm{H}, 7.90$; $\mathrm{N}, 8.04$.

1,3,4,5-Tetrahydroxy-cyclohexanecarboxylic acid (2-amino-ethyl)-amide (10). In a $50 \mathrm{~mL}$ round-bottom flask fitted with a stirring bar, $0.22 \mathrm{~g}$ amide $\mathbf{9}(0.65 \mathrm{mmol})$, then $10 \mathrm{~mL}$ solution (TFA : $\mathrm{CH}_{2} \mathrm{Cl}_{2}=1: 1$ ) was added, stirred for $1 \mathrm{hr}$ under argon. Reaction mixture was evaporated to dry under reduced pressure. Then $10 \mathrm{~mL} 1.25 \mathrm{M}$ HCl- Methanol solution was added, stirred for $1 \mathrm{hr}$ under argon. Reaction mixture was evaporated to dry under reduced pressure. Collect product 10, $175 \mathrm{mg}$ ( $99 \%$ yield). MS: $[\mathrm{M}-\mathrm{Cl}]^{+}=235 ;{ }^{1} \mathrm{H}$ NMR (300 MHz, DMSO) $1.73-1.81(\mathrm{~m}, 4 \mathrm{H}), 2.85$ (dd, J=12, $6 \mathrm{~Hz}$, $2 \mathrm{H}), 3.22(\mathrm{dd}, \mathrm{J}=8.4,3 \mathrm{~Hz}, 1 \mathrm{H}), 3.32(\mathrm{~d}, 2 \mathrm{H}), 3.72$ - $3.94(\mathrm{~m}, 1 \mathrm{H}), 3.95(\mathrm{~d}, \mathrm{~J}=4.5 \mathrm{~Hz}, 1 \mathrm{H})$, $4.02-4.52(4 \mathrm{H}), 7.91(\mathrm{~s}, 3 \mathrm{H}), 8.09(\mathrm{t}, \mathrm{J}=6.0 \mathrm{~Hz}, 1 \mathrm{H})$. Anal. $\left(\mathrm{C}_{9} \mathrm{H}_{19} \mathrm{ClN}_{2} \mathrm{O}_{5}, 0.5 \mathrm{H}_{2} \mathrm{O}\right)$ calculated: C, 37.42; H, 7.33; Cl, 112.28; N, 9.70. Found: C, 37.42; H, 7.39.

Piperidin-1-yl-(1,3,4,5-tetrahydroxy-cyclohexyl)-methanone (11). In a $50 \mathrm{~mL}$ round-bottom flask fitted with a stirring bar, reflux condenser, $0.20 \mathrm{~g}$ Lactone 2 (1.14 $\mathrm{mmol})$, and piperidine $(1.04 \mathrm{~mL}, 0.89 \mathrm{~g}, 10.49 \mathrm{mmol})$ were combined, then glacial acetic acid $(0.20 \mathrm{~mL}, 3.50 \mathrm{mmol})$ was added. The solution was warmed to $85^{\circ} \mathrm{C}$ in oil bath for 220 min under argon, at which time TLC $\left(\mathrm{CHCl}_{3}: \mathrm{MeOH}: \mathrm{NH}_{3} \mathrm{OH}=100: 10: 1\right)$ indicated complete consumption of the starting lactone. Reaction mixture was purified by flash column with same solvent as TLC. Collect product 11, $135 \mathrm{mg}$ (44.9\% yield). Rf 0.05 $\left(\mathrm{CHCl}_{3}: \mathrm{MeOH}: \mathrm{NH}_{3} \mathrm{OH}=100: 10: 1\right) ; \mathrm{MS}:[\mathrm{M}+\mathrm{Na}]^{+}=282 ;{ }^{1} \mathrm{H}$ NMR $(300 \mathrm{MHz}, \mathrm{DMSO})$ $1.57-1.72(\mathrm{~m}, 7 \mathrm{H}), 1.88-1.96(\mathrm{~m}, 3 \mathrm{H}) 3.20-3.26(\mathrm{~m}, 1 \mathrm{H}), 3.4(\mathrm{~m}, 2 \mathrm{H}), 3.69-3.83(\mathrm{~m}$, $4 \mathrm{H}), 4.62(\mathrm{~d}, \mathrm{~J}=4.5 \mathrm{~Hz}, 1 \mathrm{H}), 5.00(\mathrm{~d}, \mathrm{~J}=4.8 \mathrm{~Hz}, 1 \mathrm{H}), 5.08(\mathrm{~d}, \mathrm{~J}=5.4 \mathrm{~Hz}, 1 \mathrm{H}), 5.56(\mathrm{~s}, 1 \mathrm{H})$. Anal. $\left(\mathrm{C}_{12} \mathrm{H}_{21} \mathrm{NO}_{5} .0 .33 \mathrm{H}_{2} \mathrm{O}\right)$ calculated: $\mathrm{C}, 54.33 ; \mathrm{H}, 8.23 ; \mathrm{N}, 5.28$. Found: $\mathrm{C}, 54.66 ; \mathrm{H}$, $8.24 ; \mathrm{N}, 5.30$.

1,3,4,5-Tetraacetoxy-cyclohexanecarboxylic acid (12). In a $50 \mathrm{~mL}$ roundbottom flask fitted with a stirring bar, $1.35 \mathrm{~g}$ quinic qcid $1(7.03 \mathrm{mmol})$, and $15 \mathrm{~mL}$ anhydrous pyridine, were added. Cooled in an ice bath under argon, $15 \mathrm{~mL}$ acetic anhydride was added dropwise, warmed to rt slowly, stirred for $24 \mathrm{hr}$ at rt. The solvent was removed under high vacuum to get yellow foam. The residue was purified by flash column with solvent (EtOAc: Hex =1:1 v/v). Collect product 12, $2.41 \mathrm{~g}$ (97\% yield). Rf 0.12 (EtOAc: $\mathrm{Hex}=1: 1 \mathrm{v} / \mathrm{v})$; MS: $[\mathrm{M}-\mathrm{H}]^{-}=359 ;{ }^{1} \mathrm{H}$ NMR $(300 \mathrm{MHz}, \mathrm{DMSO}) 2.07-$ $2.25(\mathrm{~m}, 16 \mathrm{H}), 5.09(\mathrm{~m}, 1 \mathrm{H}), 5.23(\mathrm{~m}, 1 \mathrm{H}), 5.37(\mathrm{~m}, 1 \mathrm{H}), 13.24(\mathrm{~s}, 1 \mathrm{H})$. Anal. $\left(\mathrm{C}_{15} \mathrm{H}_{20} \mathrm{O}_{10}\right)$ calculated: C, 50.00; H, 5.59. Found: C, 50.61; H, 5,87.

1,3,4,5-Tetrahydroxy-cyclohexanecarboxylic acid isopropylamide (13). In a $50 \mathrm{~mL}$ round-bottom flask fitted with a stirring bar, reflux condenser, $0.19 \mathrm{~g}$ Lactone 2 $(1.12 \mathrm{mmol})$, and isopropylamine $(0.82 \mathrm{~mL}, 0.59 \mathrm{~g}, 10.13 \mathrm{mmol})$ were combined, then glacial acetic acid $(0.20 \mathrm{~mL}, 0.20 \mathrm{~g}, 3.36 \mathrm{mmol})$ was added. The solution was warmed to $85^{\circ} \mathrm{C}$ in oil bath for $30 \mathrm{~min}$, at which time TLC $\left(\mathrm{CHCl}_{3}: \mathrm{MeOH}: \mathrm{NH}_{3} \mathrm{OH}=100: 10: 1\right)$ indicated complete consumption of the starting lactone. The solvent was removed under 
reduced pressure. The residue was purified by flash column with same solvent as TLC. Collect product 13, $170 \mathrm{mg}\left(75 \%\right.$ yield). $\mathrm{R}_{\mathrm{f}} 0.03\left(\mathrm{CHCl}_{3}: \mathrm{MeOH}: \mathrm{NH}_{3} \mathrm{OH}=100: 10: 1\right)$; MS: $[\mathrm{M}+\mathrm{H}]^{+}=234 ;{ }^{1} \mathrm{H}$ NMR (300 MHz, DMSO) $\delta 1.02(\mathrm{~d}, \mathrm{~J}=6.6 \mathrm{~Hz}, 6 \mathrm{H}), 1.61-1.78(\mathrm{~m}$, 4H), $3.18(\mathrm{t}, \mathrm{J}=3.6 \mathrm{~Hz}, 1 \mathrm{H}), 3.71-3.85(\mathrm{~m}, 2 \mathrm{H}), 3.94(\mathrm{~s}, 1 \mathrm{H}), 3.90(\mathrm{~s}, 1 \mathrm{H}), 4.64(\mathrm{~d}$, $\mathrm{J}=3.9 \mathrm{~Hz}, 1 \mathrm{H}), 4.83(\mathrm{~d}, \mathrm{~J}=3.3 \mathrm{~Hz}, 1 \mathrm{H}), 5.15(\mathrm{~s}, 1 \mathrm{H}), 7.38$ (d, J=8.1 Hz, 1H). Anal. $\left(\mathrm{C}_{10} \mathrm{H}_{19} \mathrm{NO}_{5}\right)$ calculated: $\mathrm{C}, 51.49 ; \mathrm{H}, 8.21 ; \mathrm{N}, 6.00$. Found: $\mathrm{C}, 51.58 ; \mathrm{H}, 8.15 ; \mathrm{N}, 5.83$.

8-Hydroxy-4,4-dimethyl-3,5,10-trioxa-tricyclo[6.2.1.0 $\left.{ }^{2,6}\right]$ undecan-9-one (14). A mixture of quinic qcid (1) $(20 \mathrm{~g}, 104.1 \mathrm{mMol})$, p-totuenesulfonic acid monohydrate $(0.2 \mathrm{~g})$, 2,2-dimethoxypropane (38g, $364 \mathrm{mMol})$, and acetone ( $100 \mathrm{~mL}$ ) was heated to reflux for $2 \mathrm{hr}$. The reaction mixture was cooled down, and solvent was removed under reduced pressure. The residue was dissolved in ethyl acetate $(100 \mathrm{~mL})$, washed with $5 \%$ aqueous sodium bicarbonate $(100 \mathrm{~mL})$. The aqueous phase was back-extracted with ethyl acetate $(50 \times 2 \mathrm{~mL})$. The combined organic extracts were dried $\left(\mathrm{Na}_{2} \mathrm{SO}_{4}\right)$, filtered, and the solvents were removed in vacuo. The residue was crystallized with hot ethyl acetate, got white solid $1416 \mathrm{~g}$ (80\% yield). $\mathrm{mp}$ : $147-149^{\circ} \mathrm{C} \mathrm{R}_{\mathrm{f}}=0.3$ (EtoAC: $\left.\mathrm{Hex}=3: 7\right)$. MS:

$[\mathrm{M}+\mathrm{Na}]^{+}=237 .{ }^{1} \mathrm{H} \mathrm{NMR}\left(\mathrm{CDCl}_{3}\right) \delta 1.37(\mathrm{~s}, 3 \mathrm{H}), 1.55(\mathrm{~s}, 3 \mathrm{H}), 2.21(\mathrm{dd}, \mathrm{J}=14.7,3.0 \mathrm{~Hz}$, $1 \mathrm{H}), 2.30-2.44(\mathrm{~m}, 2 \mathrm{H}), 2.68(\mathrm{~d}, \mathrm{~J}=11.7 \mathrm{~Hz}, 1 \mathrm{H}), 2.83(\mathrm{~s}, 1 \mathrm{H}), 4.32-4.36(\mathrm{~m}, 1 \mathrm{H}), 4.51-$ $4.58(\mathrm{~m}, 1 \mathrm{H}), 4.79(\mathrm{dd}, \mathrm{J}=2.6,6.3 \mathrm{~Hz}, 1 \mathrm{H})$.

5,7-Dihydroxy-2,2-dimethyl-hexahydro-benzo[1,3]dioxole-5-carboxylic acid propylamide (15). Lactone (14), (10g, $46.7 \mathrm{mMol})$, propylamine $(30 \mathrm{~mL})$, and glacial acetic acid $(10 \mathrm{~mL})$ was refluxed under argon with oil bath $\left(85^{\circ} \mathrm{C}\right)$ for $45 \mathrm{~min}$. Solvents were removed under reduced pressure. The residue was washed with saturated sodium bicarbonate solution $(100 \mathrm{~mL})$, extracted with ethyl acetate $(100 \times 3 \mathrm{~mL})$. The combined organic extracts were dried $\left(\mathrm{Na}_{2} \mathrm{SO}_{4}\right)$, filtered, and the solvents were removed in vacuo. The residue was crystallized with hot ethyl acetate, got white solid $159.7 \mathrm{~g}$ (76\% yield). mp: $85-86^{\circ} \mathrm{C}, \mathrm{R}_{\mathrm{f}}=0.15$ (EtoAC: $\mathrm{Hex}=2: 1$ ). $\mathrm{MS}:[\mathrm{M}+\mathrm{Na}]^{+}=296 .{ }^{1} \mathrm{H}$ NMR (DMSO) $\delta$ $0.83(\mathrm{t}, \mathrm{J}=6.0 \mathrm{~Hz}, 3 \mathrm{H}), 1.24(\mathrm{~s}, 3 \mathrm{H}), 1.38(\mathrm{~s}, 3 \mathrm{H}), 1.40-1.45(\mathrm{~m}, 2 \mathrm{H}), 1.61-1.64(\mathrm{~m}, 2 \mathrm{H})$, $1.72(\mathrm{dd}, \mathrm{J}=14.7,5.7 \mathrm{~Hz}, 1 \mathrm{H}), 2.04(\mathrm{dd}, \mathrm{J}=14.7,5.7 \mathrm{~Hz}, 1 \mathrm{H}), 3.01$ (dd, J=6.6, 7.2 Hz, 2H), 3.80 (ddd, J=9.9, 6.3, 3.6 Hz, 2H), 4.31 (d, J=5.4 Hz, 1H), 5.01 (d, J=5.1 Hz, 1H), 5 . $28(\mathrm{~s}, 1 \mathrm{H}), 7.73(\mathrm{t}, \mathrm{J}=5.7 \mathrm{~Hz}, 1 \mathrm{H})$.

1,3,4,5-tetrahydroxy-cyclohexane-carboxylic acid propylamide (3a). The amide $(15)(5.0 \mathrm{~g})$ was dissolved in water $(10 \mathrm{~mL})$, then added aq. $1 \mathrm{M} \mathrm{HCl}(40 \mathrm{~mL})$ at room temperature. The reaction mixture was stirred at room temperature for $1 \mathrm{hr}$. Solvent was removed under reduced pressure. Residue $\mathrm{HCl}$ was removed by adding EtOEt $(20 \mathrm{x}$ $3 \mathrm{~mL}$ ) under vacuo. The residue was further dried under oil pump. Collect product 3a.26g (100\% yield). mp: $132-133^{\circ} \mathrm{C}, \mathrm{R}_{\mathrm{f}} 0.03\left(\mathrm{CHCl}_{3}: \mathrm{MeOH}: \mathrm{NH}_{3} \mathrm{OH}=100: 10: 1\right)$; $\mathrm{MS}$ : $[\mathrm{M}-\mathrm{H}]^{-=} 232 ;{ }^{1} \mathrm{H}$ NMR $(300 \mathrm{MHz}, \mathrm{DMSO}) \delta 0.81(\mathrm{t}, \mathrm{J}=6.0 \mathrm{~Hz}, 3 \mathrm{H}), 1.41$ (ddd, J=13.8, 7.5, $6.9 \mathrm{~Hz}, 2 \mathrm{H}) 1.66-1.83(\mathrm{~m}, 4 \mathrm{H}), 3.02(\mathrm{dd}, \mathrm{J}=6.9,6.6 \mathrm{~Hz}, 2 \mathrm{H}), 3.22(\mathrm{t}, \mathrm{J}=6.0 \mathrm{~Hz}, 1 \mathrm{H})$, 3.75 (ddd, J=13.8, 9.0, $5.7 \mathrm{~Hz}, 1 \mathrm{H}), 3.94(\mathrm{~s}, 1 \mathrm{H}), 4.69$ (d, J=4.5 Hz, 1H), 4.90 (d, J=5.4 $\mathrm{Hz}, 1 \mathrm{H}), 5.19(\mathrm{~d}, \mathrm{~J}=3.6 \mathrm{~Hz}, 1 \mathrm{H}), 5.47(\mathrm{~s}, 1 \mathrm{H}), 7.76(\mathrm{t}, \mathrm{J}=5.4 \mathrm{~Hz}, 1 \mathrm{H})$. Anal. $\left(\mathrm{C}_{10} \mathrm{H}_{19} \mathrm{NO}_{5}\right)$ calculated: C, 51.49; H, 8.21; N, 6.00. Found: C, 51.57; H, 8.40; N, 6.01. 


\subsubsection{Biology}

All chemicals and solvents were purchased from Sigma Aldrich Chemical Co. (St. Louis, MO) if not specified, and were used without any further purification. TNF-alpha was purchased from Invitrogen (Carlsbad, CA). Great EscAPe SEAP Chemilumi Kit was purchase from Clontech Lab, Inc. (Mountain View, CA).

\subsubsection{A549SN cell line and culture}

A549 cells (ATCC), which are a human lung adenocarcinoma cell line representative of alveolar type II epithelium, were maintained in a $5 \% \mathrm{CO}_{2}$ incubator at $37^{\circ} \mathrm{C}$ using BME (Cellgrow) supplemented with $10 \%$ heat-inactivated fetal calf serum, $2 \mathrm{mM}$ L-glutamine (Gibco), 100U/mL penicillin- $100 \mu \mathrm{g} / \mathrm{mL}$ streptomycin (Gibco). The

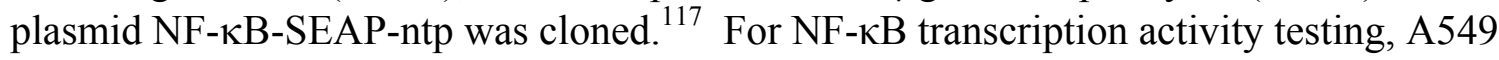
cells were transfected with NF-kB-SEAP-ntp plasmid, this is the A549SN cell line.

\subsubsection{NF- $\kappa B$ activity - A549SN cell SEAP method}

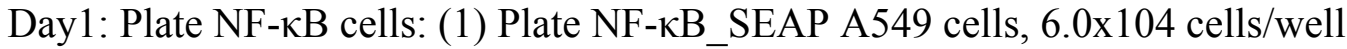
in three 24 well plates, $1000 \mu \mathrm{L}$ DMEM complete medium: 10\% heat inactivated FBS, $2 \mathrm{mM} \mathrm{L}-\mathrm{Glu}, 100 \mathrm{U} / \mathrm{mL}$ or $100 \mu \mathrm{g} / \mathrm{mL}$ Penn $/ \mathrm{Strep}, 500 \mu \mathrm{g} / \mathrm{mL}$ G418. (2) Incubate at $37^{\circ} \mathrm{C}$ incubator with $5 \% \mathrm{CO}_{2}$. Day2: Treat cells with drugs: Cells are all alive, not confluent ( $25-40 \%)$. Treat cells with QA $=1 \mu \mathrm{M}$, or other compounds @ $1 \mu \mathrm{M}(990 \mu \mathrm{L} 1 \%$ FBS DMEM + $10 \mu 1$ (10/500) PBS diluted compounds from $5 \mathrm{mM}$ in DMSO), $+10 \mathrm{ng} / \mathrm{mL}$ $\mathrm{TNF} \alpha$, for 24 hrs. Day 3: Measure SEAP activity: $24 \mathrm{~h}$ later, take out $50 \mu \mathrm{L}$ medium. Store at $-20^{\circ} \mathrm{C}$. Use Clontech "Great EscAPe SEAP Chemiluminescence Detection Kit" (Cat\# K2041-1) to measure luminescence through microplate luninometer (Packard $\alpha \mathrm{HT}$

microplate reader). Measure 1 second for once at RT. Cells left in plate were lysed in 250 $\mu \mathrm{l}$ lysis buffer $\left(10 \mathrm{mMK}_{2} \mathrm{HPO}_{4} ; 1 \mathrm{mMKH}_{2} \mathrm{PO}_{4} ; 1 \%\right.$ Triton X100;1mMDTT) for protein quantification (Pierce BCA Protein Assay Kit, Microplate Procedure) and SEAP activity was normalized to the total protein content. Inhibitory potency $\left(\mathrm{IC}_{50}\right)$ was determined from dose-response curves ( $\mathrm{n}=3$, separate experiment).

\subsubsection{MTS -cytotoxicity studies in cultured human lung adenocarcinoma A549SN cells}

A549SN cells were suspended in culture medium at a density of $10 \times 10^{4}$ cells $/ \mathrm{mL}$. Then $1 \times 10^{4}$ cells in $200 \mu \mathrm{L}$ were plated into 96 -well flat-bottom plates. Following incubation for 24 hours at $37^{\circ} \mathrm{C}$, drugs, vehicles and controls consisting only of medium and cells were dispensed in $200 \mu \mathrm{L}$ volumes in duplicate into the appropriate wells, and incubated for 18 hours. QA derivatives were tested at concentrations ranging from 0.01 to $100 \mathrm{uM}$. Cell viability was assessed by the MTS-CellTiter $96 \AA$ aqueous non-radioactive cell proliferation assay (Promega, Madison, WI, USA) according to the manufacturer's protocol after 2 hours of culture. The number of living cells in the culture 
is directly proportional to the absorbance at $490 \mathrm{~nm}$ by a formazan product bioreduced from MTS by living cells. Absorbance was measured using a DTX 880 multimode detector (Beckman Coulter, Fullerton, CA). The absorbance of media-only well was subtracted from reading of control or treated wells.

\subsubsection{Anti-oxidant activity test method}

The DPPH and all standard antioxidant compounds including trolox were dissolved in 50\% acetone. The DPPH stock solution at a concentration of $0.625 \mathrm{mM}$ was prepared monthly and kept at $4{ }^{\circ} \mathrm{C}$ in dark. The $0.208 \mathrm{mM}$ fresh DPPH working solution was made daily by further diluting the stock solution in $50 \%$ acetone for each test. Stock solutions of CA, CGA, AA and compound $\mathbf{3}$ were prepared in $50 \%$ acetone at concentrations of $10 \mathrm{mM}$, respectively, and stored at $4^{\circ} \mathrm{C}$. A series of working solutions were made by appropriate dilutions of the above standard phenolic acid stock solutions with $50 \%$ acetone.

\subsubsection{Conventional colorimetric analysis}

The conventional colorimetric DPPH scavenging capacity assay was performed according to a previously described laboratory protocol. ${ }^{116}$ Briefly, an aliquot of $500 \mu \mathrm{L}$ of different concentrations of sample extracts in $50 \%$ acetone was added to $500 \mu \mathrm{L}$ of $0.208 \mathrm{mM}$ DPPH solution. The initial concentration was $0.104 \mathrm{mM}$ for DPPH in all reaction mixtures. Each mixture was vortexed for a few seconds and test immediately. The absorbance $(A)$ of each reaction mixture at $515 \mathrm{~nm}$ was measured against a blank of $50 \%$ acetone using a UV-visible spectrometer. The level of DPPH remaining for each reaction time was calculated as: \% DPPH remaining $=\left(\mathrm{A}_{\text {sample-t }} / \mathrm{A}_{\text {control }}\right) \times 100$.

\subsubsection{Carrageenan induced paw edema}

Carrageenan $1 \%$ in sterile filtered saline $(10 \mathrm{mg} / \mathrm{mL})$ using lysing matrix $\mathrm{D}$ tubes, add saline to the tube first, then add Carrageenan, vortex for $2-3$ minutes, heat in $60^{\circ} \mathrm{C}$ water bath for 1 hour, vortex 2-3 min, inject $100 \mu \mathrm{L}$ into plantar region of right hind paw. Dexamethasone: $0.5 \mathrm{mg} / \mathrm{kg}$ in normal saline with $2 \% \mathrm{EtOH}$ administered intraperitoneally (i.p.) Recommended volume $10 \mathrm{~mL} / \mathrm{kg}$ (2-3 mL depending on weight). Should be $\sim 200-300$ g per rat, will prepare $100 \mu \mathrm{g} / \mathrm{mL}$ solution and calculate the injection volume based on the weight of the rat. Treatment: $50 \mathrm{mg} / \mathrm{kg}$ in $90 \%$ normal saline, 5\% EtOH, 5\% stepantex administered i.p. Rat were tattooed to draw line on $\mathrm{L}$ and $\mathrm{R}$ hind paw below ankle and above plantar region. Take $\mathrm{R}$ and $\mathrm{L}$ paw measurement before treatment. Inject drug solution or vehicle into the lower right quadrant by i.p. Inject $100 \mu \mathrm{L} 1 \%$ Carrageenan saline solution into plantar region of $\mathrm{R}$ hind paw. Inject $100 \mu \mathrm{L}$ Normal Saline into plantar region of $\mathrm{L}$ hind paw. Measure volume of both paws at $1,3,5$ hours. 


\section{CHAPTER 3. DESIGN AND SYNTHESIS OF QUINIC ACID DERIVATIVE ESTERS AND COMPOUND WITH DOUBLE BOND}

\subsection{Introduction}

Hot water Cat's claw extracts (e.g., C-Med 100) have very low alkaloid content $(<0.5 \%)$ and yet retain significant immune enhancing activity. Recently, quinic acid (QA) esters have been identified as biologically active components in the extract. ${ }^{1}$ Base hydrolysis of the extract dramatically reduces biological activity. For example, the lactone ester of QA (QAL) inhibits proliferation of mitogen-stimulated mouse lymphocytes, whereas QA does not affect proliferation. ${ }^{2}$ Further, base hydrolysis of the extract dramatically reduces its anti-proliferative effect against HL-60 and human mononuclear cells. ${ }^{1}$ Together, these data suggest the ester derivatives of QA found in the extract comprise a significant fraction of the biological activity.

The first three steps of QA catabolism are an NAD-dependent oxidation to form dehydroquinate, followed by two successive dehydrations to form dehydroshikimate and shikimate. ${ }^{16}$ Several research groups have made QA derivatives to target the QA catabolism enzymes. Kim made analogues as influenza neuraminidase inhibitors with potent snti-anfluenza activity. ${ }^{91}$ Sanchez-Sixto and Metaferia made compounds to kill Mycobacterium tuberculosis. ${ }^{92,93}$ Payne designed derivatives to act as type II dehydroquinase inhibitors. ${ }^{94}$ We have identified water soluble QA amide $\mathbf{3}$ which possess potent anti-inflammatory activity. ${ }^{118,119}$ QA amide lead $\mathbf{3}$ will serve as a new template for anti-inflammatory agents. We plan to investigate the importance of the hydroxyl groups on the cyclohexane ring by preparing the dehydroquinate amide $\mathbf{3}$ analogs. We also plan to investigate the importance of double bonds on the cyclohexane ring by preparing the dehydroquinate double bond amide 3 analogs. We hypothesize these modifications will retain anti-inflammatory activity with enhanced resistance to microbial degradation. Because the first three steps of QA catabolism by bacteria are to form dehydroquinate, followed by two successive dehydrations to form dehydroshikimate and shikimate. ${ }^{16} \mathrm{We}$ assume QA degradation by the bacteria will not take place when the new substrates lack of hydroxyl groups and/or having a double bond.

Chlorogenic acid (3-caffeoyl-D-quinic acid; CGA) is an ester formed between caffeic acid (CA) and QA. CGA and other polyphenolic compounds found in fruits act as potent antioxidants. For example, CGA and CA are both capable of scavenging $\mathrm{NO}^{\bullet},{ }^{64}$ a pro-inflammatory oxygen radical produced via the L-arginine pathway by infiltrating leucocytes. ${ }^{65}$ Interestingly, QA does not possess antioxidant activity suggesting alternative mechanisms underlie its anti-inflammatory activity. ${ }^{64}$ In 2001 , Sefkow has

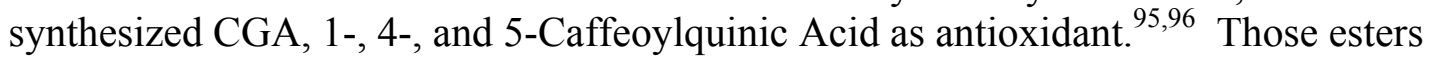
have many other properties such as antibacterial, antimutagenic, antitumor, and antiviral. ${ }^{97}$ Metaferia synthesized QA derivatives macrolides that inhibit breast cancer cell migration in vitro. ${ }^{98}$ QA amide 3 does not possess antioxidant activity as showed in Chapter 2. Based on QA amide 3 lead which serves as a new template for antiinflammatory agents, we are now planning to investigate to see if antioxidant groups are 
added for having both anti-inflammatory and antioxidant activity. We will prepare a serial of QA amide ester analogs with antioxidant groups such as caffeic acid, sinapic acid. We hypothesize these modifications will retain anti-inflammatory activity with additional antioxidant property. Furthermore, they will be hydrolyzed by the microflora, for an example, CGA is hydrolyzed into Caffeic acid and QA. ${ }^{77,78}$ Both caffeic acid and QA amide will not be consumed by gut bacteria, and easily be absorbed in animal digestive tract.

\subsection{Results and Discussion}

\subsubsection{Synthesis of Quinic Acid Derivatives}

Synthesis of 3, 4-Dihydroxy-cyclohexanecarboxylic acid propylamide 18 and 1,3,4-Trihydroxy-cyclohexanecarboxylic acid propylamide $\mathbf{2 0}$ were carried out as shown in Scheme 3-1. ${ }^{67,68,114,120}$ The synthesis of the lactone 2 was carried out using quinic acid 1 and PTSA in refluxing benzene and DMF according to the procedure of Neelu Kaila et al. with minor revision. The lactone $\mathbf{2}$ was then allowed to refluxed with $\mathrm{ClC}(\mathrm{S}) \mathrm{Cl}$ and imidazole in $\mathrm{ClCH}_{2} \mathrm{CH}_{2} \mathrm{Cl}$, and then resulting imidazole-1-carbothioic acid O-(9-oxo-4-thioxo-3,5,10-trioxa tricyclo[6.2.1.02,6] undec-8-yl) ester 16. Compound 16 was treated with $\mathrm{Bu}_{3} \mathrm{SnH} / \mathrm{xylene}$, then $\mathrm{Bu}_{3} \mathrm{SnH}$ and $\mathrm{AIBN} / \mathrm{xylene}$ to give compounds 4Hydroxy-6-oxa-bicyclo[3.2.1] octan-7-one 17 and 1,4-Dihydroxy-6-oxabicyclo[3.2.1] octan-7-one 19. The lactones $\mathbf{1 7}$ and $\mathbf{1 9}$ were then allowed to react with Npropyl amine with acetic acid at $85^{\circ} \mathrm{C}$, and then resulting amides 18 , and 20 respectively. Amides 18, and 20 were purified using flash chromatography. ${ }^{114}$

Synthesis of 3-(4-Hydroxy-3, 5-dimethoxy-phenyl)-acrylic acid 2,3,5-trihydroxy5-propylcarbamoyl-cyclohexyl ester 25 was carried out as shown in Scheme 3-2. ${ }^{96,115,121}$ The synthesis of the lactone $\mathbf{1 4}$ was carried out using quinic acid $\mathbf{1}$ and PTSA in refluxing 2,2-DMP and acetone. The lactone $\mathbf{1 4}$ was then allowed to to react with N-propyl amine with acetic acid at $85^{\circ} \mathrm{C}$, and then resulting amide $\mathbf{1 5}$. The synthesis of compound $\mathbf{2 2}$ was carried out using sinapic acid $\mathbf{2 1}$ treated with $\mathrm{Ac}_{2} \mathrm{O}$ in pyridine, DMAP, at room temperature; Compounds 15 and 22 were mixed in $\mathrm{CH}_{2} \mathrm{Cl}_{2}$, treated with DMAP, DIC, at room temperature, and then resulting 3-(4-Acetoxy-3,5-dimethoxy-phenyl)-acrylic acid 6-hydroxy-2,2-dimethyl-6-propylcarbamoyl-hexahydro-benzo[1,3]dioxol-4-yl ester $\mathbf{2 3}$. Ester 23 was treated with $1 \mathrm{~N} \mathrm{HCl}$ for 20 min, obtained compound 24; ester $\mathbf{2 3}$ was treated with $1 \mathrm{~N} \mathrm{HCl}$ for 7 days, obtained compound 25. Compounds 23, 24, and 25 were purified using flash chromatography.

3-(4-Hydroxy-3, 5-dimethoxy-phenyl)-acrylic acid 3,4,5-trihydroxy-1propylcarbamoyl-cyclohexyl ester $\mathbf{2 9}$ was synthesized as shown in Scheme 3-3. ${ }^{96,115,121}$ The synthesis of the lactone $\mathbf{1 4}$ was carried out using quinic acid $\mathbf{1}$ and PTSA in refluxing 2,2-DMP and acetone.The synthesis of compound $\mathbf{2 6}$ was carried out in two steps, first using sinapic acid 21 treated with $\mathrm{Ac}_{2} \mathrm{O}$ in pyridine, DMAP, at room temperature; then the product was refluxed in $\mathrm{SOCl}_{2}$ and $\mathrm{CH}_{2} \mathrm{Cl}_{2}$. Compounds 14 and 26 were mixed in 

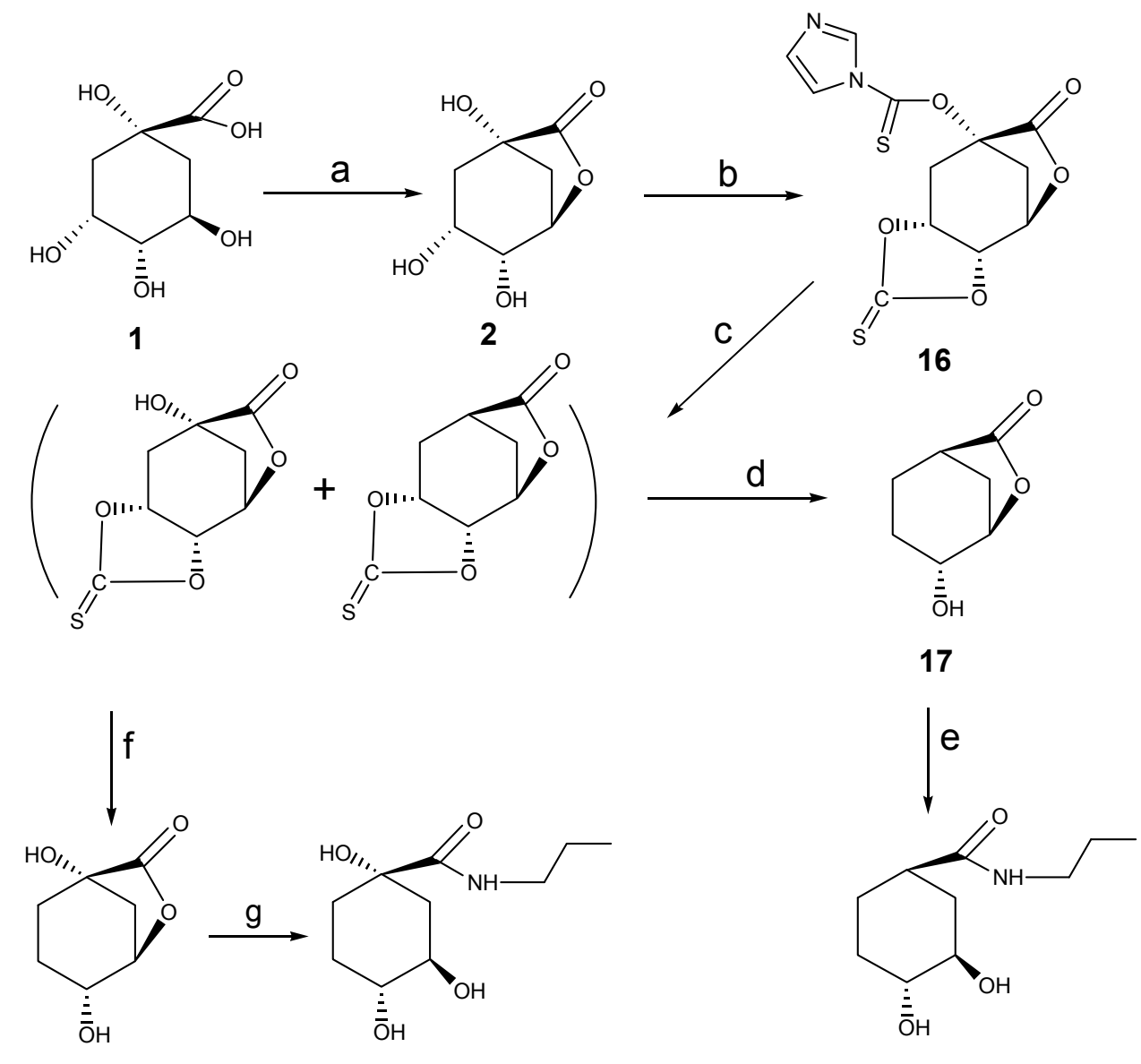

19

20

18

Scheme 3-1. Synthetic scheme of compounds 18 and 20. Reagents and conditions: (a) PTSA, DMF, $\mathrm{C}_{6} \mathrm{H}_{6}$, Dean-Stark, reflux, 78\%; (b) $\mathrm{ClC}(\mathrm{S}) \mathrm{Cl}$, imid, $\mathrm{ClCH}_{2} \mathrm{CH}_{2} \mathrm{Cl}$, reflux; (c) $\mathrm{Bu}_{3} \mathrm{SnH}$, xylene, reflux; (d) $\mathrm{Bu}_{3} \mathrm{SnH}$, AIBN, xylene, reflux; (e) $\mathrm{C}_{3} \mathrm{H}_{7}-\mathrm{NH}_{2}, \mathrm{AcOH}$, oil bath $85^{\circ} \mathrm{C}$; (f) $\mathrm{Bu}_{3} \mathrm{SnH}$, AIBN, xylene, reflux; (g) $\mathrm{C}_{3} \mathrm{H}_{7}-\mathrm{NH}_{2}, \mathrm{AcOH}$, oil bath $85^{\circ} \mathrm{C}$. 


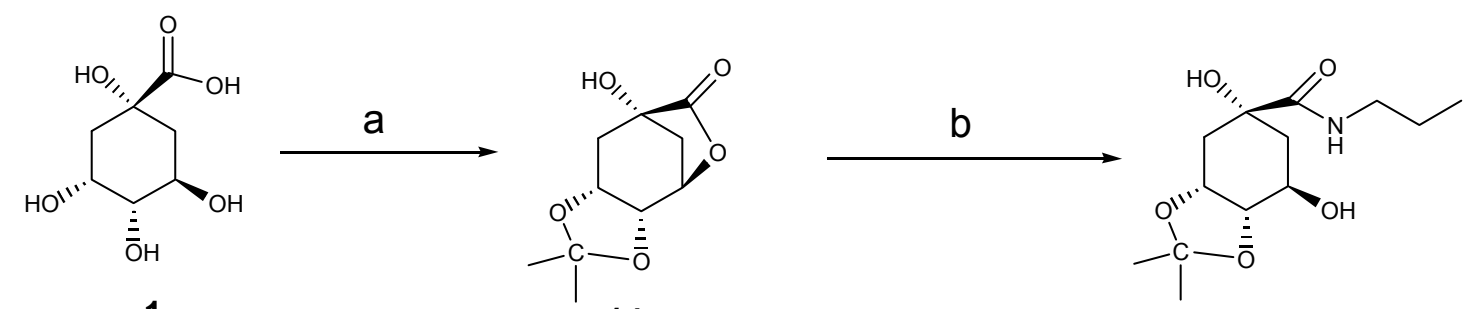<smiles>COc1cc(/C=C/C(=O)O)cc(OC)c1O</smiles>

14

15

21

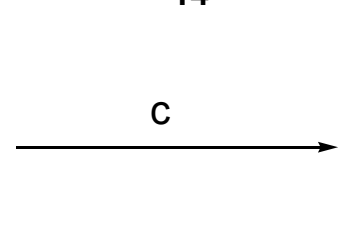<smiles>COc1cc(/C=C/C(=O)O)cc(OC)c1OC</smiles>

22<smiles>CCCNC(=O)[C@@]1(O)C[C@@H](O)[C@@H](O)[C@H](OC(=O)/C=C/c2cc(OC)c(OC)c(OC)c2)C1</smiles><smiles>CCCNC(=O)[C@]1(O)C[C@@H]2OC(C)(C)O[C@H]2[C@H](OC(=O)/C=C/c2cc(OC)c(OC)c(OC)c2)C1</smiles><smiles>CCCNC(=O)[C@@]1(O)CC(OC(=O)/C=C/c2cc(OC)c(O)c(OC)c2)[C@@H](O)[C@H](O)C1</smiles>

Scheme 3-2. Synthetic scheme of compound 25. Reagents and conditions: (a) PTSA, 2,2-DMP, Acetone, reflux, 80\%; (b) $\mathrm{C}_{3} \mathrm{H}_{7}-\mathrm{NH}_{2}, \mathrm{AcOH}$, oil bath $85^{\circ} \mathrm{C}$; (c) $\mathrm{Ac}_{2} \mathrm{O}$, Pyridine, DMAP, rt; (d) $\mathrm{CH}_{2} \mathrm{Cl}_{2}$, DMAP, DIC, rt; (e) $1 \mathrm{~N} \mathrm{HCl}$, rt, 20 min; (f) $1 \mathrm{~N} \mathrm{HCl}$, rt, 7 days. 


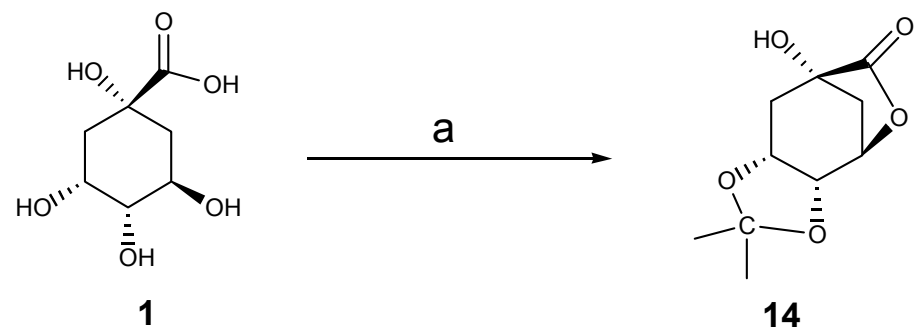<smiles>COc1cc(/C=C/C(=O)O)cc(OC)c1O</smiles>
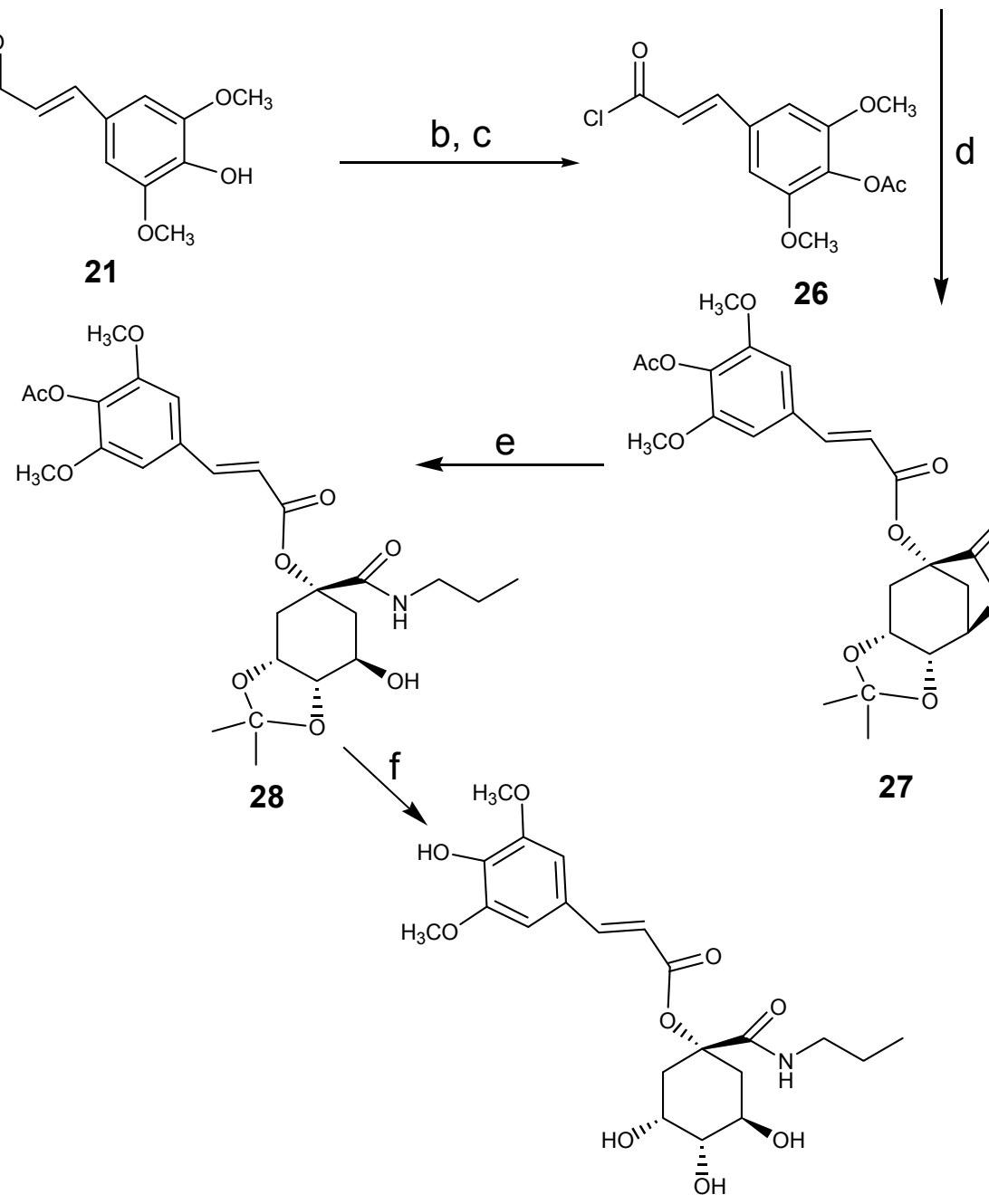

29

Scheme 3-3. Synthetic scheme of compound 29. Reagents and conditions: (a) PTSA, 2,2-DMP, Acetone, reflux, $80 \%$; (b) $\mathrm{Ac}_{2} \mathrm{O}$, Pyridine, DMAP, rt; (c) $\mathrm{SOCl}_{2}, \mathrm{CH}_{2} \mathrm{Cl}_{2}$, reflux; (d) $\mathrm{CH}_{2} \mathrm{Cl}_{2}$, Pyridine, DMAP, rt; (e) $\mathrm{C}_{3} \mathrm{H}_{7}-\mathrm{NH}_{2}, \mathrm{AcOH}$, oil bath $85^{\circ} \mathrm{C}$; (f) $1 \mathrm{~N} \mathrm{HCl}$, rt, 5 days. 
$\mathrm{CH}_{2} \mathrm{Cl}_{2}$, treated with DMAP, Pyridine, at room temperature, and then resulting ester 27. Ester 27 was allowed to react with N-propyl amine with acetic acid at $85^{\circ} \mathrm{C}$, and then resulting ester 28; Compound 29 was carried out using ester 28 treated with $1 \mathrm{~N} \mathrm{HCl}$ for 5 days. Compounds 29 were purified using flash chromatography.

3-(4-Hydroxy-3,5-dimethoxy-phenyl)-acrylic acid 2,3,5-trihydroxy-5propylcarbamoyl-cyclohexyl ester 33 was synthesized as shown in Scheme 3-4. ${ }^{96,115,121}$ The synthesis of the lactone $\mathbf{1 4}$ was carried out using quinic acid 1 and PTSA in refluxing 2,2-DMP and acetone. lactone 14 was allowed to react with N-propyl amine with acetic acid at $85^{\circ} \mathrm{C}$, and then resulting ester 15 ; The synthesis of compound 31 was carried out in two steps, first using caffeic acid $\mathbf{3 0}$ treated with $\mathrm{Ac}_{2} \mathrm{O}$ in pyridine, DMAP, at room temperature; then the product was refluxed in $\mathrm{SOCl}_{2}$ and $\mathrm{CH}_{2} \mathrm{Cl}_{2}$. Compounds 15 and 31 were mixed in $\mathrm{CH}_{2} \mathrm{Cl}_{2}$, treated with DMAP, Pyridine, at room temperature, and then resulting ester 32. Compound $\mathbf{3 3}$ was carried out using ester $\mathbf{3 2}$ treated with $1 \mathrm{~N} \mathrm{HCl}$ for 5 days. Compounds $\mathbf{3 3}$ were purified using flash chromatography.

The synthesis of 1,4,5-Trihydroxy-cyclohex-2-enecarboxylic acid propylamide 38 was shown in Scheme 3-5. ${ }^{122-124}$ Compound 34 was synthesized by using quinic acid 1 and PTSA in refluxing benzaldehyde and benzene. lactone 34 was allowed to react with NBS, AIBN, reluxed in benzene, and then resulting ester 35; The synthesis of compound 36 was carried out using compound 35 treated with DBU, tert-butyldimethylsilyl chloride in acetonitrile, refluxed. Compounds 36 was allowed to react with $\mathrm{N}$-propyl amine with acetic acid at $85^{\circ} \mathrm{C}$, and then resulting amide 37 . Compound 38 was carried out using amide 37 treated with $1 \mathrm{M}$ TBAF solution. Compounds $\mathbf{3 8}$ were purified using flash chromatography.

\subsubsection{Biology Testing of Dehydroxyl QA Amides and Esters}

The results of dehydroxyl QA amides anti-inflammatory high throughput

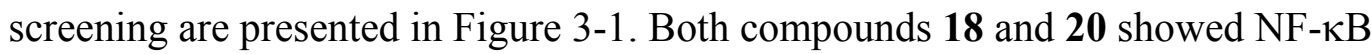
inhibition at concentration $1 \mu \mathrm{M}$. The extent of NF- $\kappa \mathrm{B}$ inhibition was close to positive control drug dexamethasone. The compounds 18, 20 and $\mathbf{3 8}$ were designed to retain antiinflammatory activity while having enhanced resistance to microbial degradation. Their biological activities were tested by other researchers. The compounds $\mathbf{2 5 , 2 9}$ and 33 were designed to retain anti-inflammatory activity with additional antioxidant properties.

Furthermore, they were hydrolyzed by the microflora, for an example, $\mathbf{2 5}$ was hydrolyzed into SA and 3. Both SA and 3 will not be consumed by gut bacteria, and easily be absorbed in animal digestive tract. This was done by other researchers, and not reported here. Mechanistic studies and pre-clinical efficacy studies of these newly designed compounds in various in vitro and in vivo models are on-going by other researchers, and are not reported in this dissertation.

Next, we determined the anti-oxidant potential of QA derivatives using the 2, 2diphenyl-1-picrylhydrazyl (DPPH) free radical scavenging method. ${ }^{116}$ As expected, caffeic acid (CA), sinapic acid (SA) and compound 25 showed strong anti-oxidant 


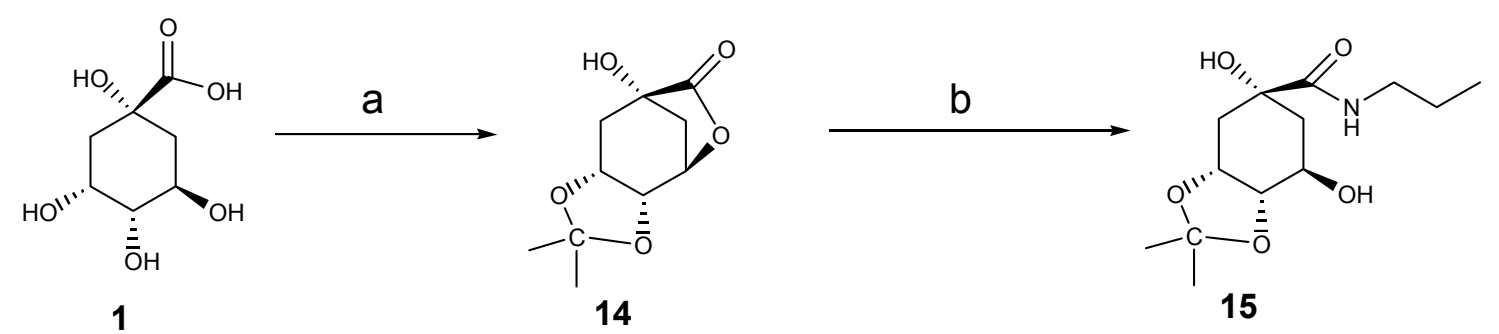

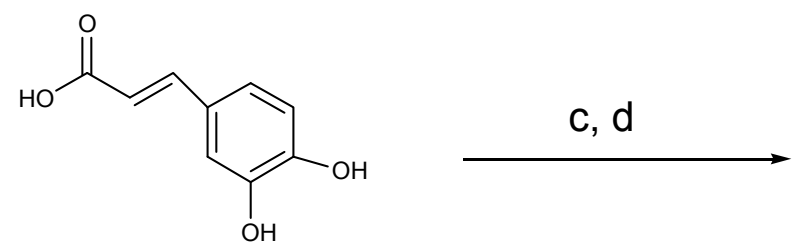

30<smiles>CCCNC(=O)[C@@]1(O)C[C@H](OC(=O)/C=C/c2ccc(O)c(O)c2)[C@H](O)[C@H](O)C1</smiles>

33
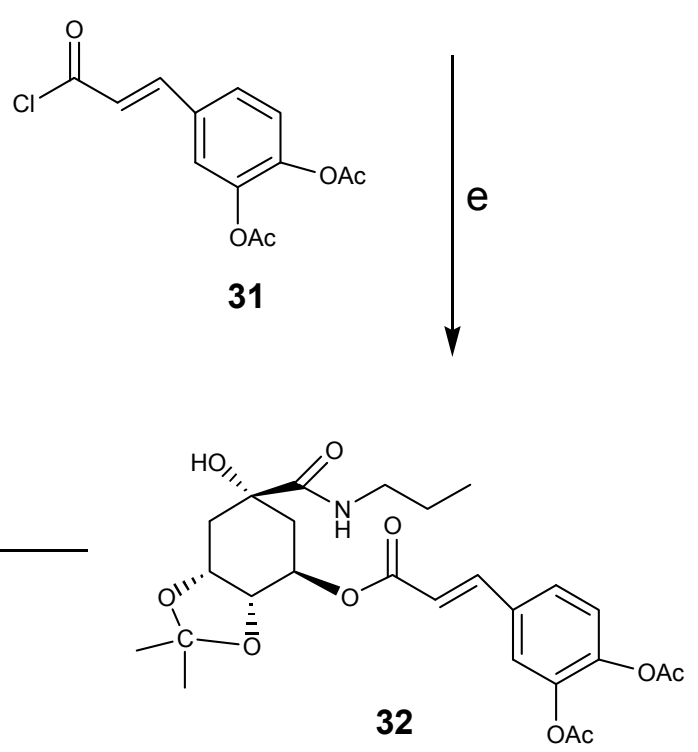

Scheme 3-4. Synthetic scheme of compound 33. Reagents and conditions: (a) PTSA, 2,2-DMP, Acetone, reflux, 80\%; (b) $\mathrm{C}_{3} \mathrm{H}_{7}-\mathrm{NH}_{2}, \mathrm{AcOH}$, oil bath $85^{\circ} \mathrm{C}$; (c) $\mathrm{Ac}_{2} \mathrm{O}$, Pyridine, DMAP, rt; (d) $\mathrm{SOCl}_{2}, \mathrm{CH}_{2} \mathrm{Cl}_{2}$, reflux; (e) $\mathrm{CH}_{2} \mathrm{Cl}_{2}$, Pyridine, DMAP, rt; (f) $1 \mathrm{~N} \mathrm{HCl}$, rt, 5 days. 
<smiles>O=C(O)[C@]1(O)C[C@@H](O)[C@H](O)[C@H](O)C1</smiles>

1<smiles>O=C1O[C@@H]2C[C@]1(O)C[C@@H]1OC(c3ccccc3)O[C@@H]12</smiles>

$\stackrel{\mathrm{b}}{\longrightarrow}$<smiles>O=C(O)C1OC(=O)[C@]2(O)CC(Br)C1C2</smiles>

35

C

$\downarrow$<smiles>CCCNC(=O)[C@]1(O)C=CC(O)C(O)C1</smiles>

38

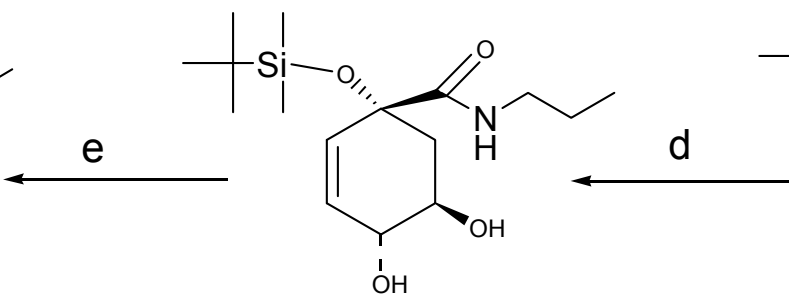

37

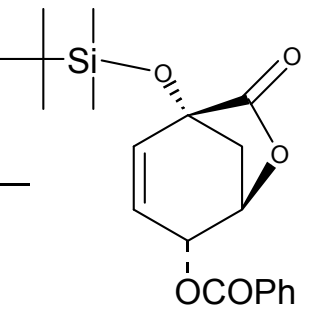

36

Scheme 3-5. Synthetic scheme of compound 38. Reagents and conditions: (a) PTSA, Benzaldehyde, Benzene, reflux; (b) NBS, AIBN, Benzene, reflux; (c) DBU, tertbutyldimethylsilyl chloride, Acetonitrile, reflux; (d) $\mathrm{C}_{3} \mathrm{H}_{7}-\mathrm{NH}_{2}, \mathrm{AcOH}$, oil bath $85^{\circ} \mathrm{C}$; (e) TBAF, THF. 


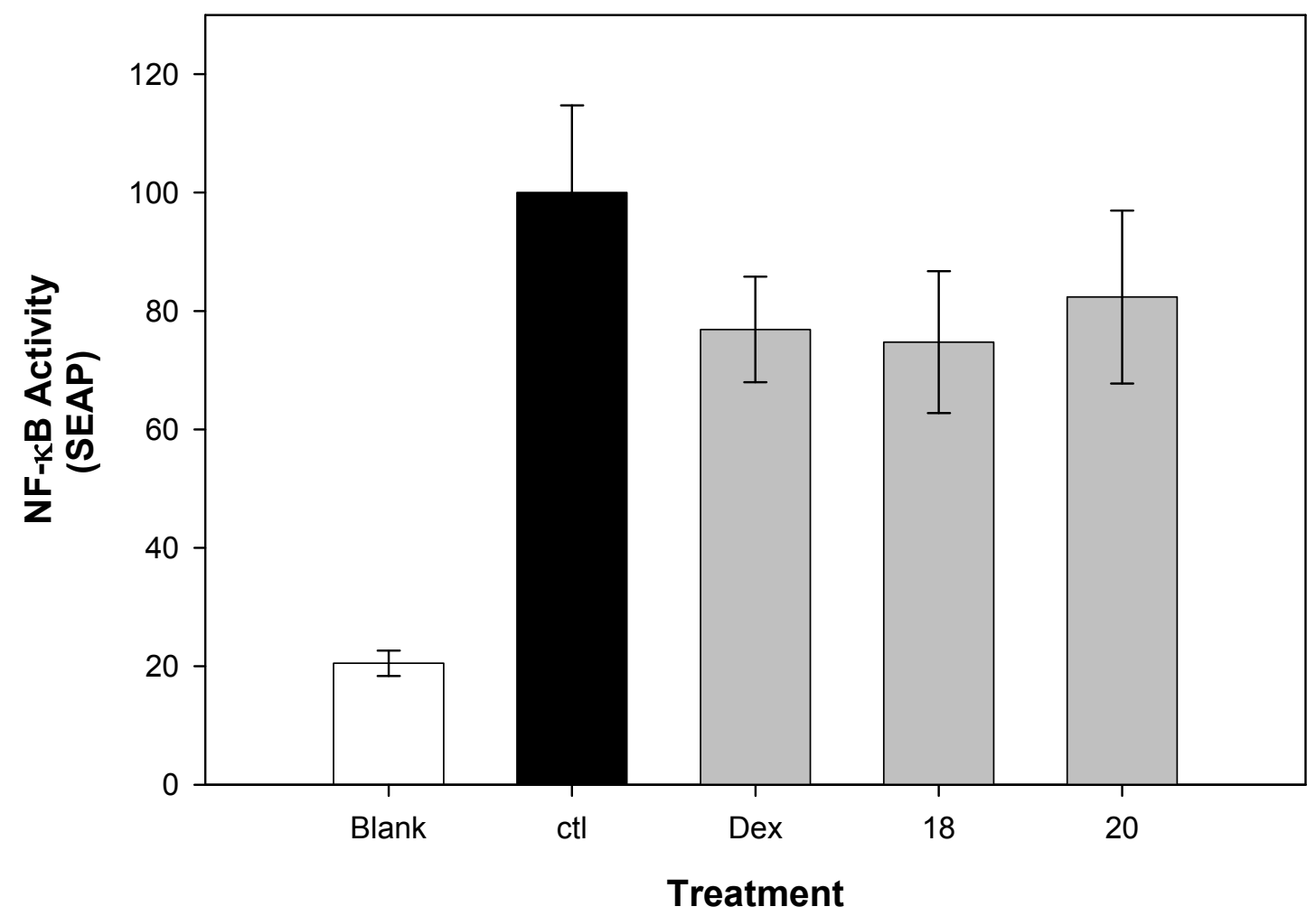

Figure 3-1. NF-кB inhibition by KZ-41 derivatives using A549 cells stably transfected with a secreted alkaline phosphatase (SEAP) reporter. NF- $\kappa B$ activity was measured 18 hours after addition of TNF- $\alpha(10 \mathrm{ng} / \mathrm{mL})$ and QA synthesized derivatives $(\mathbf{1 8}, \mathbf{2 0} ; 1 \mu \mathrm{M})$. Dexamethasone (Dex; $1 \mu \mathrm{M})$ was used as a positive control. Data are presented as percent (\%) inhibition relative to control (ctl; TNF- $\alpha$ alone) and represent mean $\%$ inhibition \pm standard deviation $(\mathrm{n}=3)$. Blank: media only. 
activity, while $\mathbf{2 4}$ had no anti-oxidant activity (Figure 3-2). The fact that $\mathbf{2 4}$ does not possess anti-oxidant activity is consistent with a previous report. ${ }^{64}$ Because it does not bear a free phenolic group could act as antioxidants. ${ }^{80,81}$

\subsection{Conclusions}

The dehydroxyl QA amides 18 and 20 were synthesized. They showed NF- $\kappa B$ inhibition at concentration $1 \mu \mathrm{M}$. The extent of NF- $\kappa \mathrm{B}$ inhibition was close to positive control drug dexamethasone. The dehydroxyl QA amide with a double bond $\mathbf{3 8}$ was also synthesized. The QA amide esters 24, 25, 29 and 33 were designed and synthesized. As expected, compound $\mathbf{2 5}$ showed strong anti-oxidant activity. Furthermore, they were hydrolyzed by the microflora, for an example, 25 was hydrolyzed into SA and $\mathbf{3}$. Both SA and 3 will not be consumed by gut bacteria, and easily be absorbed in animal digestive tract. Mechanistic studies and pre-clinical efficacy studies of these newly designed compounds in various in vitro and in vivo models are on-going by other researchers, and are not reported in this dissertation.

\subsection{Experimental}

\subsubsection{Chemistry}

All reagents and solvents were purchased from Sigma Aldrich Chemical Co. (St. Louis, MO), Fischer Scientific (Pittsburgh, PA), and TCI (Portland, OR), and were used without any further purification. Thin layer chromatography (TLC) was performed on silica gel chromatogram plates purchased from Analtech, Inc. Flash chromatography was performed either on silica gel (60 $\AA, 200-425$ mesh) or on pre-packed silica gel columns by using a Horizon HPFC system (Biotage, Charlottesville, VA). Molecular masses were collected with electron spray ionization mass spectra (ESI-MS) on a Bruker/Hewlett Packard Esquire LC/MS instrument. Nuclear magnetic resonance (NMR) spectra for ${ }^{1} \mathrm{H}$ NMR and ${ }^{13} \mathrm{C}$ NMR were recorded on a Bruker ARX 300 instrument and/or a Varian Inova-500 MHz instrument. The chemical shifts value $(\delta)$ are reported in parts per million (ppm) relative to tetramethylsilane (TMS), and coupling constants (J) were reported in hertz. Peaks are abbreviated as were indicated as follows: s, singlet; d, doublet; t, triplet; m, multiplet. Deuterated solvents were purchased from Cambridge Isotope Laboratories, Inc. Melting points were determined on a Fisher-Johns melting point apparatus and are uncorrected. Elemental analyses $(\mathrm{C}, \mathrm{H}, \mathrm{N})$ were performed by Atlantic Microlab Inc. (Norcross, GA), and are accepted within \pm 0.4 of the theoretical values. High performance liquid chromatography (HPLC) separation was performed on a Hewlett Packard LC instrument with model 1100 system.

Imidazole-1-carbothioic acid O-(9-oxo-4-thioxo-3, 5, 10-trioxa tricycle [6.2.1.02, 6] undec-8-yl) ester (16). In a $250 \mathrm{~mL}$ round-bottom flask fitted with a stirring bar, reflux condenser, and argon inlet, $7.0 \mathrm{~mL}$ of thiophosgene $(90 \mathrm{mmol})$ was 


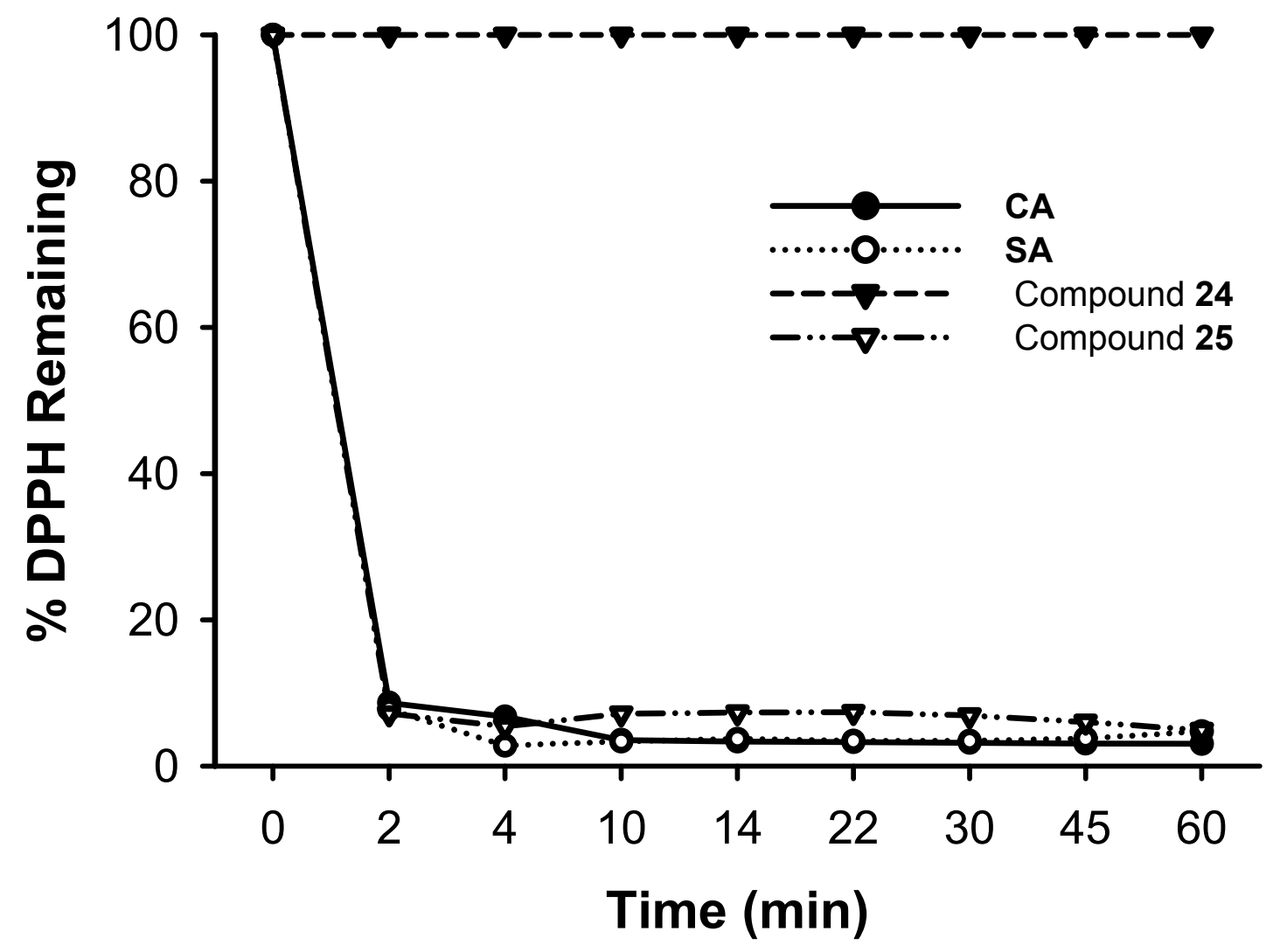

Figure 3-2. Determining antioxidant activity by reaction kinetics of DPPH. Caffeic acid (CA), sinapic acid (SA), compound $\mathbf{2 4}$ and $\mathbf{2 5}$ were prepared in 50\% acetone. The conventional colorimetric DPPH scavenging capacity was determined by UV absorption measured at $515 \mathrm{~nm}$. CA, SA and compound 25 showed strong anti-oxidant activity, while $\mathbf{2 4}$ had no anti-oxidant activity. 
added dropwise under argon to rapidly stirred suspension of imidazole $(25 \mathrm{~g})$ in dry $\mathrm{ClCH}_{2} \mathrm{CH}_{2} \mathrm{Cl}(150 \mathrm{~mL})$. Following completion of the addition, the mixture was agitated $30 \mathrm{~min}$. Then added lactone $(1,5 \mathrm{~g}, 30 \mathrm{mMol})$ in one portion, refluxed $3 \mathrm{hr}$, cooled to rt. The solvent was removed immediately under high vacuum to get dry brown oil. Added cold water $(100 \mathrm{~mL} \times 2)$, washed the residue carefully, then carefully washed the residue with acetone $(5 \mathrm{~mL} \times 3)$, filtered, collect white solid 16, $4.61 \mathrm{~g}$ (47\% yield). MS: $[\mathrm{M}+\mathrm{Na}]^{+}:$349; ${ }^{1} \mathrm{H}$ NMR (300 MHz, DMSO) $\delta 2.40(\mathrm{~d}, \mathrm{~J}=12 \mathrm{~Hz}, 1 \mathrm{H}), 2.79-2.84(\mathrm{~m}$, $1 \mathrm{H}), 3.03(\mathrm{dd}, \mathrm{J}=15.0,3.0 \mathrm{~Hz}, 1 \mathrm{H}), 3.80-3.94(\mathrm{~m}, 1 \mathrm{H}), 5.33-5.40(\mathrm{~m}, 2 \mathrm{H}), 5.63-5.70$ (m, 1H), $7.12(\mathrm{~d}, \mathrm{~J}=1.0 \mathrm{~Hz}, 1 \mathrm{H}), 7.84(\mathrm{~d}, \mathrm{~J}=1 \mathrm{~Hz}, 1 \mathrm{H}), 8.54(\mathrm{~s}, 1 \mathrm{H})$.

4-Hydroxy-6-oxa-bicyclo[3.2.1]octan-7-one (17). In a $200 \mathrm{~mL}$ round-bottom flask fitted with a stirring bar, reflux condenser, $3.26 \mathrm{~g}$ Ester $16(10 \mathrm{mmol})$, was suspended in $80 \mathrm{~mL}$ dry xylene, refluxed under argon. Treated with $2.51 \mathrm{~mL}$ TBTH first, after $30 \mathrm{~min}$, added $2.51 \mathrm{~mL}$ TBTH more, after another $1 \mathrm{hr}$, added $4.0 \mathrm{~mL}$ TBTH and $0.02 \mathrm{~g}$ AIBN, refluxed for $2.5 \mathrm{hr}$. The solvent was removed under high vacuum. Reaction residue was purified by flash column (Hex : EtOAc $=1: 1$ ). Collect product 17, $110 \mathrm{mg}$ (8\% yield). $\mathrm{R}_{\mathrm{f}} 0.13$ (Hex : EtOAc $\left.=1: 1\right)$; MS: $[\mathrm{M}+\mathrm{Na}]^{+}: 165 ;{ }^{1} \mathrm{H}$ NMR $(300 \mathrm{MHz}$, DMSO) 1.66-1.83 (m, 5H), $2.10-2.20(\mathrm{~m}, 1 \mathrm{H}), 2.24(\mathrm{~d}, \mathrm{~J}=7.8 \mathrm{~Hz}, 1 \mathrm{H}), 2.24(\mathrm{~s}, 1 \mathrm{H}), 3.89$ $(\mathrm{m}, \mathrm{J}=4.5 \mathrm{~Hz}, 1 \mathrm{H}), 4.54(\mathrm{t}, \mathrm{J}=5.4 \mathrm{~Hz}, 1 \mathrm{H}), 5.21$ (d, J=3.3 Hz, 1H).

3,4-Dihydroxy-cyclohexanecarboxylic acid propylamide (18). In a $50 \mathrm{~mL}$ round-bottom flask fitted with a stirring bar, reflux condenser, $0.25 \mathrm{~g}$ Lactone 17 (1.24 $\mathrm{mmol})$, and propylamine $(0.83 \mathrm{~mL}, 0.6 \mathrm{~g}, 10.13 \mathrm{mmol})$ were combined, then glacial acetic acid $(1.1 \mathrm{~mL}, 0.75 \mathrm{~g}, 12.71 \mathrm{mmol})$ was added. The solution was warmed to $85^{\circ} \mathrm{C}$ in oil bath for $30 \mathrm{~min}$, at which time TLC $\left(\mathrm{CHCl}_{3}: \mathrm{MeOH}: \mathrm{NH}_{3} \mathrm{OH}=100: 10: 1\right)$ indicated complete consumption of the starting lactone. The solvent was removed under reduced pressure. The residue was purified by flash column with same solvent as TLC. Collect product 17, 256mg (64\% yield). mp: $105-107^{\circ} \mathrm{C}, \mathrm{R}_{\mathrm{f}} 0.15\left(\mathrm{CHCl}_{3}: \mathrm{MeOH}: \mathrm{NH}_{3} \mathrm{OH}\right.$ $=100: 10: 1)$; MS: $[\mathrm{M}+\mathrm{Na}]^{+=} 224 ;{ }^{1} \mathrm{H}$ NMR $(300 \mathrm{MHz}, \mathrm{DMSO}) \delta 0.81(\mathrm{t}, \mathrm{J}=6.0 \mathrm{~Hz}, 3 \mathrm{H})$, 1.41-1.61 (m, 5H), $1.76(\mathrm{~d}, \mathrm{~J}=3.0 \mathrm{~Hz}, 1 \mathrm{H}), 1.81(\mathrm{~d}, \mathrm{~J}=3.0 \mathrm{~Hz}, 2 \mathrm{H}), 2.12(\mathrm{t}, \mathrm{J}=1 \mathrm{~Hz}, 1 \mathrm{H})$, $2.96(\mathrm{dd}, \mathrm{J}=6.3,12.6 \mathrm{~Hz}, 2 \mathrm{H}), 3.08(\mathrm{dd}, \mathrm{J}=4.5,9.0 \mathrm{~Hz}, 2 \mathrm{H}), 4.55(\mathrm{~d}, \mathrm{~J}=3.0 \mathrm{~Hz}, 1 \mathrm{H}), 4.60$ $(\mathrm{d}, \mathrm{J}=3.0 \mathrm{~Hz}, 1 \mathrm{H}), 7.67(\mathrm{t}, \mathrm{J}=5.4 \mathrm{~Hz}, 1 \mathrm{H})$. Anal. $\left(\mathrm{C}_{10} \mathrm{H}_{19} \mathrm{NO}_{3}\right)$ calculated: $\mathrm{C}, 59.68 ; \mathrm{H}$, 9.52; N, 6.96. Found: C, 59.25; H, 9.46; N, 6.91.

1,4-Dihydroxy-6-oxa-bicyclo[3.2.1]octan-7-one (19). In a $200 \mathrm{~mL}$ round-bottom flask fitted with a stirring bar, reflux condenser, $3.26 \mathrm{~g}$ Ester 16 (10 mmol), was suspended in $80 \mathrm{~mL}$ dry xylene, refluxed under argon. Treated with $2.51 \mathrm{~mL}$ TBTH first, after $30 \mathrm{~min}$, added $2.51 \mathrm{~mL}$ TBTH more, after another $1 \mathrm{hr}$, added $4.0 \mathrm{~mL}$ TBTH and $0.02 \mathrm{~g}$ AIBN, refluxed for $2.5 \mathrm{hr}$. The solvent was removed under high vacuum. Reaction residue was purified by flash column (Hex : EtOAc $=1: 1)$. Collect product 19, $220 \mathrm{mg}$ (14\% yield). $\mathrm{R}_{\mathrm{f}} 0.08(\mathrm{Hex}: \mathrm{EtOAc}=1: 1)$; MS: $[\mathrm{M}+\mathrm{Na}]^{+}: 181 ;{ }^{1} \mathrm{H}$ NMR $(300 \mathrm{MHz}$, DMSO) 1.66-1.83 (m, 4H), $2.10-2.20(\mathrm{~m}, 1 \mathrm{H}), 2.24(\mathrm{~d}, \mathrm{~J}=7.8 \mathrm{~Hz}, 1 \mathrm{H}), 2.24(\mathrm{~s}, 1 \mathrm{H}), 3.89$ $(\mathrm{m}, \mathrm{J}=4.5 \mathrm{~Hz}, 1 \mathrm{H}), 4.54(\mathrm{t}, \mathrm{J}=5.4 \mathrm{~Hz}, 1 \mathrm{H}), 5.21(\mathrm{~d}, \mathrm{~J}=3.3 \mathrm{~Hz}, 1 \mathrm{H}), 5.84(\mathrm{~s}, 1 \mathrm{H})$.

1,3,4-Trihydroxy-cyclohexanecarboxylic acid propylamide (20). In a $50 \mathrm{~mL}$ round-bottom flask fitted with a stirring bar, reflux condenser, 0.30g Lactone 19 (1.90 
mmol), and propylamine $(0.83 \mathrm{~mL}, 0.6 \mathrm{~g}, 10.13 \mathrm{mmol})$ were combined, then glacial acetic acid $(1.3 \mathrm{~mL}, 0.94 \mathrm{~g}, 15.93 \mathrm{mmol})$ was added. The solution was warmed to $85^{\circ} \mathrm{C}$ in oil bath for $30 \mathrm{~min}$, at which time TLC $\left(\mathrm{CHCl}_{3}: \mathrm{MeOH}: \mathrm{NH}_{3} \mathrm{OH}=100: 10: 1\right)$ indicated complete consumption of the starting lactone. The solvent was removed under reduced pressure. The residue was purified by flash column with same solvent as TLC. Collect product 20, $240 \mathrm{mg}$ (58\% yield). mp: $151-154^{\circ} \mathrm{C}, \mathrm{R}_{\mathrm{f}} 0.12\left(\mathrm{CHCl}_{3}: \mathrm{MeOH}: \mathrm{NH}_{3} \mathrm{OH}\right.$ $=100: 10: 1)$; MS: $[\mathrm{M}+\mathrm{Na}]^{+=} 240 ;{ }^{1} \mathrm{H}$ NMR $(300 \mathrm{MHz}, \mathrm{DMSO}) \delta 0.81(\mathrm{t}, \mathrm{J}=4.5 \mathrm{~Hz}, 3 \mathrm{H})$, 1.37-1.44 (m, 3H), 1.51-1.71 (m, 5H), $3.00(\mathrm{q}, \mathrm{J}=6.6 \mathrm{~Hz}, 2 \mathrm{H}), 3.12(\mathrm{~m}, 1 \mathrm{H}), 3.45(\mathrm{~m}, 1 \mathrm{H})$, $4.49(\mathrm{~d}, \mathrm{~J}=1.8 \mathrm{~Hz}, 1 \mathrm{H}), 4.52(\mathrm{~d}, \mathrm{~J}=3.0 \mathrm{~Hz}, 1 \mathrm{H}), 5.17$ (s, $1 \mathrm{H}), 7.67$ (t, J=5.4 Hz, 1H). Anal. $\left(\mathrm{C}_{10} \mathrm{H}_{19} \mathrm{NO}_{4}\right)$ calculated: $\mathrm{C}, 55.28 ; \mathrm{H}, 8.81 ; \mathrm{N}, 6.45$. Found: $\mathrm{C}, 55.12 ; \mathrm{H}, 8.72 ; \mathrm{N}, 6.50$.

3-(4-Acetoxy-3,5-dimethoxy-phenyl)-acrylic acid (22). In a $50 \mathrm{~mL}$ roundbottom flask fitted with a stirring bar, $1.0 \mathrm{~g}$ Sinapic acid $21(4.46 \mathrm{mmol})$, and $0.02 \mathrm{~g}$ DMAP were combined in $15 \mathrm{~mL}$ anhydrous pyridine, then $\mathrm{Ac}_{2} \mathrm{O}(0.56 \mathrm{~mL}, 0.57 \mathrm{~g}, 5.57$ mmol) was added under ice bath. The reaction mixture was stirred for $2 \mathrm{hr}$, then poured onto crushed ice. The aqueous phase was acidified with $2 \mathrm{M}$ aqueous $\mathrm{HCl}(\mathrm{pH}=2)$ and extracted with EtOAc $(3 \times 80 \mathrm{~mL})$. The combined organic extracts were dried over $\mathrm{Na}_{2} \mathrm{SO}_{4}$, filtered, the solvent was removed under reduced pressure. Titration of the residue with hexane containing small amount of EtOAc afforded acetyl sinapic acid 22 $1.2 \mathrm{~g}(98 \%$ yield $)$, white powder. MS: $[\mathrm{M}-\mathrm{H}]^{-}=265$.

3-(4-Acetoxy-3,5-dimethoxy-phenyl)-acrylic acid 6-hydroxy-2,2-dimethyl-6propylcarbamoyl-hexahydro-benzo[1,3]dioxol-4-yl ester (23). In a $100 \mathrm{~mL}$ roundbottom flask fitted with a stirring bar, lactone $(1,0.7 \mathrm{~g}, 2.56 \mathrm{mMol})$, acetyl sinapic acid 22, $(0.72 \mathrm{~g}, 2.70 \mathrm{mmol})$ were combined in $50 \mathrm{~mL}$ anhydrous $\mathrm{CH}_{2} \mathrm{Cl}_{2}$ under argon, $0.05 \mathrm{~g}$ DMAP was added, then $0.6 \mathrm{~mL}$ DIC was added at rt, stirred for 2 days. Solid urine was filtered out. Reaction mixture was washed with $0.5 \mathrm{~N} \mathrm{HCl}$, extracted with $\mathrm{CH}_{2} \mathrm{Cl}_{2}(3 \mathrm{x}$ $80 \mathrm{~mL})$. The combined organic extracts were dried over $\mathrm{Na}_{2} \mathrm{SO}_{4}$, filtered, the solvent was removed under reduced pressure. Residue was purified by flash column with solvent mixture of Hexane : Acetone (10/3, v/v). Collect white solid product 23, $825 \mathrm{mg}(62 \%$ yield). Rf 0.15 (Hexane:Acetone $=10: 3)$; MS: $[\mathrm{M}+\mathrm{Na}]^{+}=544 .{ }^{1} \mathrm{H}$ NMR $(300 \mathrm{MHz}$, DMSO) $0.81(\mathrm{t}, \mathrm{J}=4.5 \mathrm{~Hz}, 3 \mathrm{H}), 0.85(\mathrm{t}, \mathrm{J}=2.1 \mathrm{~Hz}, 1 \mathrm{H}), 1.27(\mathrm{~s}, 3 \mathrm{H}), 1.40-1.41(\mathrm{~m}, 2 \mathrm{H})$, 1.43 (s, 3H), 1.79 (d, J=4.8 Hz, 2H), 1.98 (d, J=9.0 Hz, 1H), 2.25(t, J=4.8 Hz, 3H), 3.02 $(\mathrm{m}, 2 \mathrm{H}), 3.80(\mathrm{~s}, 6 \mathrm{H}), 4.14(\mathrm{t}, \mathrm{J}=3.9 \mathrm{~Hz}, 1 \mathrm{H}), 4.44(\mathrm{~d}, \mathrm{~J}=3.0 \mathrm{~Hz}, 1 \mathrm{H}), 5.38(\mathrm{q}, \mathrm{J}=4.9 \mathrm{~Hz}$, 1H), $5.49(\mathrm{~s}, 1 \mathrm{H}), 6.75(\mathrm{~d}, \mathrm{~J}=9.9 \mathrm{~Hz}, 1 \mathrm{H}), 7.16(\mathrm{~s}, 2 \mathrm{H}), 7.70(\mathrm{~d}, \mathrm{~J}=9.9 \mathrm{~Hz}, 1 \mathrm{H}), 7.76$ (t, $\mathrm{J}=3.6 \mathrm{~Hz}, 1 \mathrm{H})$.

\section{3-(4-Acetoxy-3,5-dimethoxy-phenyl)-acrylic acid 2,3,5-trihydroxy-5}

propylcarbamoyl-cyclohexyl ester (24). In a $50 \mathrm{~mL}$ round-bottom flask fitted with a stirring bar, ester 23, $(0.23 \mathrm{~g}, 0.44 \mathrm{mmol})$ were dissoved in $5 \mathrm{~mL}$ THF, then $15 \mathrm{~mL}$ aqueous $1 \mathrm{~N} \mathrm{HCl}$ was added at $\mathrm{rt}$, stirred for $20 \mathrm{~min}$. Reaction mixture was saturated with $\mathrm{Na} \mathrm{HCO}_{3}$ solution, extracted with EtOAc $(3 \times 80 \mathrm{~mL})$. The combined organic extracts were dried over $\mathrm{Na}_{2} \mathrm{SO}_{4}$, filtered, the solvent was removed under reduced pressure. Collect white solid product 24, $200 \mathrm{mg}\left(95 \%\right.$ yield). $\mathrm{MS}:[\mathrm{M}+\mathrm{Na}]^{+}=504 .{ }^{1} \mathrm{H}$ NMR $(300$ MHz, DMSO) $0.81(\mathrm{t}, \mathrm{J}=4.5 \mathrm{~Hz}, 3 \mathrm{H}), 1.25(\mathrm{~m}, 2 \mathrm{H}), 1.41(\mathrm{~m}, 2 \mathrm{H}), 1.78(\mathrm{~d}, \mathrm{~J}=15 \mathrm{~Hz}, 1 \mathrm{H})$, $1.93(\mathrm{~m}, 2 \mathrm{H}), 2.25(\mathrm{~s}, 3 \mathrm{H}), 3.02(\mathrm{~m}, 2 \mathrm{H}), 3.58(\mathrm{~m}, 1 \mathrm{H}), 3.81(\mathrm{~s}, 6 \mathrm{H}), 4.10(\mathrm{t}, \mathrm{J}=3.9 \mathrm{~Hz}$, 
$1 \mathrm{H}), 5.05(\mathrm{~d}, \mathrm{~J}=6.0 \mathrm{~Hz}, 1 \mathrm{H}), 5.28(\mathrm{q}, \mathrm{J}=6.3 \mathrm{~Hz}, 1 \mathrm{H}), 5.59(\mathrm{~s}, 1 \mathrm{H}), 5.70(\mathrm{~d}, \mathrm{~J}=3.9 \mathrm{~Hz}, 1 \mathrm{H})$, $6.75(\mathrm{~d}, \mathrm{~J}=16 \mathrm{~Hz}, 1 \mathrm{H}), 7.16(\mathrm{~s}, 2 \mathrm{H}), 7.63$ (d, J=16 Hz, 1H), 7.76 (t, J=3.6 Hz, 1H).

3-(4-Hydroxy-3,5-dimethoxy-phenyl)-acrylic acid 2,3,5-trihydroxy-5propylcarbamoyl-cyclohexyl ester (25). In a $100 \mathrm{~mL}$ round-bottom flask fitted with a stirring bar, ester 23, $(0.50 \mathrm{~g}, 0.96 \mathrm{mmol})$ were dissoved in $10 \mathrm{~mL}$ THF, then $30 \mathrm{~mL}$ aqueous $1 \mathrm{~N} \mathrm{HCl}$ was added at $\mathrm{rt}$. The reaction mixture was stirred at $\mathrm{rt}$, and progress was monitored by ESI-MS. After 7 days, reaction was completed. Reaction mixture was killed with $\mathrm{Na} \mathrm{HCO}_{3}$ solution, and saturated with $\mathrm{NaCl}$, extracted with EtOAc (3 x $80 \mathrm{~mL}$ ). The combined organic extracts were dried over $\mathrm{Na}_{2} \mathrm{SO}_{4}$, filtered, the solvent was removed under reduced pressure. The residue was purified by flash column $\left(\mathrm{CHCl}_{3}: \mathrm{MeOH}: \mathrm{NH}_{3} \mathrm{OH}=100: 10: 1\right)$, Collect white solid product 25, $210 \mathrm{mg}$ (50\% yield). $\mathrm{R}_{\mathrm{f}}=0.16\left(\mathrm{CHCl}_{3}: \mathrm{MeOH}: \mathrm{NH}_{3} \mathrm{OH}=100: 10: 1\right), \mathrm{MS}:[\mathrm{M}+\mathrm{Na}]^{+}=462 .{ }^{1} \mathrm{H}$ NMR $(300 \mathrm{MHz}$, DMSO) $0.80(\mathrm{t}, \mathrm{J}=4.5 \mathrm{~Hz}, 3 \mathrm{H}), 1.41(\mathrm{~m}, 2 \mathrm{H}), 1.75(\mathrm{~d}, \mathrm{~J}=9.0 \mathrm{~Hz}, 1 \mathrm{H}), 1.89(\mathrm{~m}, 1 \mathrm{H}), 1.98$ $(\mathrm{m}, 2 \mathrm{H}), 3.02(\mathrm{~m}, 2 \mathrm{H}), 3.56(\mathrm{~m}, 1 \mathrm{H}), 3.81(\mathrm{~s}, 6 \mathrm{H}), 4.10(\mathrm{~s}, 1 \mathrm{H}), 5.01(\mathrm{~d}, \mathrm{~J}=3.3 \mathrm{~Hz}, 1 \mathrm{H})$, $5.28(\mathrm{q}, \mathrm{J}=3.0 \mathrm{~Hz}, 1 \mathrm{H}), 5.58(\mathrm{~s}, 1 \mathrm{H}), 5.67$ (d, J=3.0 Hz, 1H), 6.52 (d, J=9.6 Hz, 1H), 7.02 $(\mathrm{s}, 2 \mathrm{H}), 7.56(\mathrm{~d}, \mathrm{~J}=9.6 \mathrm{~Hz}, 1 \mathrm{H}), 7.75(\mathrm{t}, \mathrm{J}=3.6 \mathrm{~Hz}, 1 \mathrm{H}), 8.92(\mathrm{~s}, 1 \mathrm{H})$. Anal. $\left(\mathrm{C}_{21} \mathrm{H}_{29} \mathrm{NO}_{9}\right.$. $0.33 \mathrm{H}_{2} \mathrm{O}$ ) calculated: C, 56.62; H, 6.71; N, 3.14. Found: C, 56.53; H, 6.75; N, 3.00.

Acetic acid 4-(2-chlorocarbonyl-vinyl)-2,6-dimethoxy-phenyl ester (26). In a $50 \mathrm{~mL}$ round-bottom flask fitted with a stirring bar, $1.0 \mathrm{~g}$ Sinapic acid 21 (4.46 mmol), and $0.02 \mathrm{~g}$ DMAP were combined in $15 \mathrm{~mL}$ anhydrous pyridine, then $\mathrm{Ac}_{2} \mathrm{O}(0.56 \mathrm{~mL}$, $0.57 \mathrm{~g}, 5.57 \mathrm{mmol}$ ) was added under ice bath. The reaction mixture was stirred for $2 \mathrm{hr}$, then poured onto crushed ice. The aqueous phase was acidified with $2 \mathrm{M}$ aqueous $\mathrm{HCl}$ $(\mathrm{pH}=2)$ and extracted with EtOAc $(3 \times 80 \mathrm{~mL})$. The combined organic extracts were dried over $\mathrm{Na}_{2} \mathrm{SO}_{4}$, filtered, the solvent was removed under reduced pressure. Titration of the residue with hexane containing small amount of EtOAc afforded acetyl sinapic acid $221.2 \mathrm{~g}(98 \%$ yield $)$, white powder. MS: $[\mathrm{M}-\mathrm{H}]^{-=} 265$.

In a $50 \mathrm{~mL}$ round-bottom flask fitted with a stirring bar, $0.6 \mathrm{~g}$ acetyl sinapic acid $22(2.26 \mathrm{mmol})$, was dissolved in $20 \mathrm{~mL} \mathrm{CH}_{2} \mathrm{Cl}_{2}$, then $0.8 \mathrm{~mL} \mathrm{SOCl}_{2}$ was added. The reaction mixture was refluxed $3 \mathrm{hr}$ under argon. The solvent was removed under reduced pressure, residue was white solid 26.

3-(4-Acetoxy-3,5-dimethoxy-phenyl)-acrylic acid 4,4-dimethyl-9-oxo-3,5,10trioxa-tricyclo[6.2.1] undec-8-yl ester (27). In a $100 \mathrm{~mL}$ round-bottom flask fitted with a stirring bar, lactone $(\mathbf{1 4}, 0.6 \mathrm{~g}, 2.56 \mathrm{mMol})$, compound $(\mathbf{2 6}, 2.26 \mathrm{mmol})$ were combined in $50 \mathrm{~mL}$ anhydrous $\mathrm{CH}_{2} \mathrm{Cl}_{2}$ under argon, $0.5 \mathrm{~g}$ DMAP was added, then $10 \mathrm{~mL}$ anhydrous pyridine was added at rt, stirred overnight under argon. The solvent was removed under reduced pressure. Reaction mixture was washed with $50 \mathrm{~mL} 0.5 \mathrm{~N} \mathrm{HCl}$, extracted with EtOAc $(3 \times 50 \mathrm{~mL})$. The combined organic extracts were dried over $\mathrm{Na}_{2} \mathrm{SO}_{4}$, filtered, the solvent was removed under reduced pressure. Residue was purified by flash column with solvent mixture of Hexane : EtOAc (7/3, v/v). Collect white solid product 27, $605 \mathrm{mg}$ (58\% yield). Rf 0.14 (Hexane:EtOAc $=7: 3)$; MS: $[\mathrm{M}+\mathrm{Na}]^{+}=485 .{ }^{1} \mathrm{H}$ NMR $(300 \mathrm{MHz}$, DMSO) 1.27 (s, 3H), 1.47 (s, 3H), 2.26(t, J=4.8 Hz, 3H), 2.31 (d, J=3.3 Hz, 1H), 2.43 $2.46(\mathrm{~m}, 2 \mathrm{H}), 3.02(\mathrm{~m}, 1 \mathrm{H}), 3.81(\mathrm{~s}, 6 \mathrm{H}), 4.58(\mathrm{~d}, \mathrm{~J}=4.9 \mathrm{~Hz}, 1 \mathrm{H}), 4.60(\mathrm{td}, \mathrm{J}=8.8,3.0 \mathrm{~Hz}$, 
1H), $4.96(\mathrm{dd}, \mathrm{J}=6.0,2.4 \mathrm{~Hz}, 1 \mathrm{H}), 6.81(\mathrm{~d}, \mathrm{~J}=16 \mathrm{~Hz}, 1 \mathrm{H}), 7.19$ (s, 2H), 7.70 (d, J=16 Hz, $1 \mathrm{H})$.

1,3,4,5-tetrahydroxy-cyclohexane-carboxylic acid propylamide (28). In a 50 $\mathrm{mL}$ round-bottom flask fitted with a stirring bar, reflux condenser, $0.40 \mathrm{~g}$ Lactone 27 $(0.87 \mathrm{mmol})$, and propylamine $(0.83 \mathrm{~mL}, 0.6 \mathrm{~g}, 10.13 \mathrm{mmol})$ were combined, then glacial acetic acid $(0.64 \mathrm{~mL}, 0.46 \mathrm{~g}, 7.80 \mathrm{mmol})$ was added. The solution was warmed to $85^{\circ} \mathrm{C}$ in oil bath for $45 \mathrm{~min}$, at which time TLC $\left(\mathrm{CHCl}_{3}: \mathrm{MeOH}: \mathrm{NH}_{3} \mathrm{OH}=100: 10: 1\right)$ indicated complete consumption of the starting lactone. The solvent was removed under reduced pressure. Residue was washed with $\mathrm{Na} \mathrm{HCO}_{3}$ solution, and saturated with $\mathrm{NaCl}$, extracted with EtOAc $(3 \times 80 \mathrm{~mL})$. The combined organic extracts were dried over $\mathrm{Na}_{2} \mathrm{SO}_{4}$, filtered, the solvent was removed under reduced pressure. Collect product white solid 28, one spot, $\mathrm{R}_{\mathrm{f}} 0.5\left(\mathrm{CHCl}_{3}: \mathrm{MeOH}: \mathrm{NH}_{3} \mathrm{OH}=100: 10: 1\right)$; $\mathrm{MS}:\left[\mathrm{M}+\mathrm{NH}_{4}\right]^{+=} 539$; used for next reaction without further purification.

\section{3-(4-Hydroxy-3,5-dimethoxy-phenyl)-acrylic acid 2,3,5-trihydroxy-5-} propylcarbamoyl-cyclohexyl ester (29). In a $100 \mathrm{~mL}$ round-bottom flask fitted with a stirring bar, ester 28, $(0.70 \mathrm{mmol})$ were dissoved in $5 \mathrm{~mL}$ THF, then $15 \mathrm{~mL}$ aqueous $1 \mathrm{~N}$ $\mathrm{HCl}$ was added at $\mathrm{rt}$. The reaction mixture was stirred at $\mathrm{rt}$, and progress was monitored by ESI-MS. After 5 days, reaction was completed. Reaction mixture was killed with $\mathrm{NaHCO}_{3}$ solution, and saturated with $\mathrm{NaCl}$, extracted with EtOAc $(3 \times 80 \mathrm{~mL})$. The combined organic extracts were dried over $\mathrm{Na}_{2} \mathrm{SO}_{4}$, filtered, the solvent was removed under reduced pressure. The residue was purified by flash column with solvent $\left(\mathrm{CHCl}_{3}: \mathrm{MeOH}: \mathrm{NH}_{3} \mathrm{OH}=100: 10: 1\right)$, Collect white solid product 29, $105 \mathrm{mg}$ (34\% yield). $\mathrm{R}_{\mathrm{f}}=0.06\left(\mathrm{CHCl}_{3}: \mathrm{MeOH}: \mathrm{NH}_{3} \mathrm{OH}=100: 10: 1\right), \mathrm{MS}:[\mathrm{M}+\mathrm{Na}]^{+}=462 .{ }^{1} \mathrm{H}$ NMR $(300 \mathrm{MHz}$, DMSO) $0.80(\mathrm{t}, \mathrm{J}=7.2 \mathrm{~Hz}, 3 \mathrm{H}), 1.32-1.44(\mathrm{~m}, 2 \mathrm{H}), 1.95-2.05(\mathrm{~m}, 4 \mathrm{H}), 2.40(\mathrm{~m}, 1 \mathrm{H})$, $3.02(\mathrm{~m}, 2 \mathrm{H}), 3.57(\mathrm{~m}, 2 \mathrm{H}), 3.81(\mathrm{~s}, 6 \mathrm{H}), 4.35(\mathrm{~d}, \mathrm{~J}=4.5 \mathrm{~Hz}, 1 \mathrm{H}), 4.65(\mathrm{~d}, \mathrm{~J}=4.5 \mathrm{~Hz}, 1 \mathrm{H})$, $5.34(\mathrm{~d}, \mathrm{~J}=5.4 \mathrm{~Hz}, 1 \mathrm{H}), 6.45(\mathrm{~d}, \mathrm{~J}=16 \mathrm{~Hz}, 1 \mathrm{H}), 7.00(\mathrm{~s}, 2 \mathrm{H}), 7.50$ (d, J=16 Hz, 1H), 8.03 (t, $\mathrm{J}=5.7 \mathrm{~Hz}, 1 \mathrm{H}), 8.94(\mathrm{~s}, 1 \mathrm{H})$. Anal. $\left(\mathrm{C}_{21} \mathrm{H}_{29} \mathrm{NO}_{9} .1 .33 \mathrm{H}_{2} \mathrm{O}\right)$ calculated: $\mathrm{C}, 54.42 ; \mathrm{H}, 6.89$; $\mathrm{N}, 3.02$. Found: C, 54.56; H, 6.79; N, 2.98 .

Acetic acid 2-acetoxy-4-(2-chlorocarbonyl-vinyl)-phenyl ester (31). In a $50 \mathrm{~mL}$ round-bottom flask fitted with a stirring bar, $1.0 \mathrm{~g}$ caffeic acid $\mathbf{3 0}(5.61 \mathrm{mmol})$, and 0.02g DMAP were combined in $15 \mathrm{~mL}$ anhydrous pyridine, then $\mathrm{Ac}_{2} \mathrm{O}(1.4 \mathrm{~mL}, 1.42 \mathrm{~g}$, $14.01 \mathrm{mmol}$ ) was added under ice bath. The reaction mixture was stirred for $2 \mathrm{hr}$, then poured onto crushed ice. The aqueous phase was acidified with $2 \mathrm{M}$ aqueous $\mathrm{HCl}(\mathrm{pH}=2)$ and extracted with EtOAc $(3 \times 80 \mathrm{~mL})$. The combined organic extracts were dried over $\mathrm{Na}_{2} \mathrm{SO}_{4}$, filtered, the solvent was removed under reduced pressure. Titration of the residue with hexane containing small amount of EtOAc afforded acetyl caffeic acid $1.2 \mathrm{~g}$ (98\% yield), white powder. MS: $[\mathrm{M}-\mathrm{H}]^{-}=263$.

In a $50 \mathrm{~mL}$ round-bottom flask fitted with a stirring bar, $0.7 \mathrm{~g}$ acetyl caffeic acid ( $2.65 \mathrm{mmol}$ ), was dissolved in $20 \mathrm{~mL} \mathrm{CH}_{2} \mathrm{Cl}_{2}$, then $0.8 \mathrm{~mL} \mathrm{SOCl} \mathrm{S}_{2}$ was added. The reaction mixture was refluxed $3 \mathrm{hr}$ under argon. The solvent was removed under reduced pressure, residue was white solid 31. 


\section{3-(3,4-Diacetoxy-phenyl)-acrylic acid 6-hydroxy-2,2-dimethyl-6-}

propylcarbamoyl-hexahydro-benzo[1,3]dioxol-4-yl ester (32). In a $100 \mathrm{~mL}$ roundbottom flask fitted with a stirring bar, compound $15(0.7 \mathrm{~g}, 2.56 \mathrm{mMol})$, compound (31, $2.26 \mathrm{mmol}$ ) were combined in $50 \mathrm{~mL}$ anhydrous $\mathrm{CH}_{2} \mathrm{Cl}_{2}$ under argon, $0.05 \mathrm{~g}$ DMAP was added, then $10 \mathrm{~mL}$ anhydrous pyridine was added at rt, stirred overnight under argon. The solvent was removed under reduced pressure. Reaction mixture was washed with 50 $\mathrm{mL} 0.5 \mathrm{~N} \mathrm{HCl}$, extracted with EtOAc $(3 \times 50 \mathrm{~mL})$. The combined organic extracts were dried over $\mathrm{Na}_{2} \mathrm{SO}_{4}$, filtered, the solvent was removed under reduced pressure. Residue was purified by flash column with solvent mixture of $\mathrm{CH}_{2} \mathrm{Cl}_{2}: \mathrm{MeOH}(98 / 2, \mathrm{v} / \mathrm{v})$. Collect white solid product 32, $750 \mathrm{mg}$ (56\% yield). $\mathrm{Rf} 0.44\left(\mathrm{CH}_{2} \mathrm{Cl}_{2}: \mathrm{MeOH}=98: 2\right)$; MS: $[\mathrm{M}+\mathrm{Na}]^{+}=442 .{ }^{1} \mathrm{H}$ NMR $(300 \mathrm{MHz}, \mathrm{DMSO}) 0.81(\mathrm{t}, \mathrm{J}=7.5 \mathrm{~Hz}, 3 \mathrm{H}), 1.26(\mathrm{~s}, 3 \mathrm{H}), 1.33-$ $1.40(\mathrm{~m}, 2 \mathrm{H}), 1.41(\mathrm{~s}, 3 \mathrm{H}), 1.78(\mathrm{~d}, \mathrm{~J}=9.0 \mathrm{~Hz}, 2 \mathrm{H}), 1.99(\mathrm{~d}, \mathrm{~J}=5.0 \mathrm{~Hz}, 1 \mathrm{H}), 2.24-2.30(\mathrm{~m}$, $2 \mathrm{H}), 2.31(\mathrm{~s}, 6 \mathrm{H}), 2.98-3.06(\mathrm{~m}, 2 \mathrm{H}), 4.13(\mathrm{~m}, 1 \mathrm{H}), 4.42(\mathrm{~m}, 1 \mathrm{H}), 5.31-5.41(\mathrm{~m}, 1 \mathrm{H})$, $5.46(\mathrm{~s}, 1 \mathrm{H}), 6.64(\mathrm{~d}, \mathrm{~J}=16 \mathrm{~Hz}, 1 \mathrm{H}), 7.32(\mathrm{~d}, \mathrm{~J}=8.4,1 \mathrm{H}), 7.65(\mathrm{~d}, \mathrm{~J}=16 \mathrm{~Hz}, 1 \mathrm{H}), 7.64$ $7.68(\mathrm{~m}, 2 \mathrm{H})$.

\section{3-(4-Hydroxy-3,5-dimethoxy-phenyl)-acrylic acid 2,3,5-trihydroxy-5-} propylcarbamoyl-cyclohexyl ester (33). In a $100 \mathrm{~mL}$ round-bottom flask fitted with a stirring bar, ester $32(0.84 \mathrm{~g}, 1.62 \mathrm{mmol})$ were dissoved in $10 \mathrm{~mL} \mathrm{THF}$, then $40 \mathrm{~mL}$ aqueous $1 \mathrm{~N} \mathrm{HCl}$ was added at $\mathrm{rt}$. The reaction mixture was stirred at $\mathrm{rt}$, and progress was monitored by ESI-MS. After 4 days, reaction was completed. Reaction mixture was killed with $\mathrm{NaHCO}_{3}$ solution, and saturated with $\mathrm{NaCl}$, extracted with EtOAc $(3$ x $80 \mathrm{~mL})$. The combined organic extracts were dried over $\mathrm{Na}_{2} \mathrm{SO}_{4}$, filtered, the solvent was removed under reduced pressure. The residue was purified by flash column with solvent $\left(\mathrm{CH}_{2} \mathrm{Cl}_{2}: \mathrm{MeOH}=10: 1\right)$, Collect white solid product 33, $260 \mathrm{mg}$ (41\% yield). $\mathrm{R}_{\mathrm{f}}=0.26$ $\left(\mathrm{CH}_{2} \mathrm{Cl}_{2}: \mathrm{MeOH}=10: 1\right), \mathrm{MS}:[\mathrm{M}+\mathrm{Na}]^{+}=418 .{ }^{1} \mathrm{H}$ NMR $(300 \mathrm{MHz}, \mathrm{DMSO}) 0.80$ (t, $\mathrm{J}=7.5 \mathrm{~Hz}, 3 \mathrm{H}), 1.37-1.44(\mathrm{~m}, 2 \mathrm{H}), 1.71(\mathrm{~d}, \mathrm{~J}=13.80 \mathrm{~Hz}, 1 \mathrm{H}), 1.87-1.995(\mathrm{~m}, 3 \mathrm{H}), 3.02$ $(\mathrm{m}, 2 \mathrm{H}), 3.57(\mathrm{~m}, 1 \mathrm{H}), 4.06(\mathrm{~s}, 1 \mathrm{H}), 5.03(\mathrm{~s}, 1 \mathrm{H}), 5.24(\mathrm{dt}, \mathrm{J}=4.0,12.3 \mathrm{~Hz}, 1 \mathrm{H}), 5.57(\mathrm{~s}$, $1 \mathrm{H}), 5.65(\mathrm{~s}, 1 \mathrm{H}), 6.23(\mathrm{~d}, \mathrm{~J}=16 \mathrm{~Hz}, 1 \mathrm{H}), 6.76(\mathrm{~d}, \mathrm{~J}=8.1 \mathrm{~Hz}, 1 \mathrm{H}), 7.01(\mathrm{~d}, \mathrm{~J}=8.1 \mathrm{~Hz}, 1 \mathrm{H})$, $7.03(\mathrm{~s}, 1 \mathrm{H}), 7.50(\mathrm{~d}, \mathrm{~J}=16 \mathrm{~Hz}, 1 \mathrm{H}), 7.73(\mathrm{t}, \mathrm{J}=6.0 \mathrm{~Hz}, 1 \mathrm{H}), 9.14(\mathrm{~s}, 1 \mathrm{H}), 9.56(\mathrm{~s}, 1 \mathrm{H})$. Anal. $\left(\mathrm{C}_{19} \mathrm{H}_{25} \mathrm{NO}_{8}\right.$. $\left.0.5 \mathrm{H}_{2} \mathrm{O}\right)$ calculated: $\mathrm{C}, 56.79 ; \mathrm{H}, 6.84 ; \mathrm{N}, 3.40$. Found: $\mathrm{C}, 56.63 ; \mathrm{H}$, $6.63 ; \mathrm{N}, 3.21$.

8-Hydroxy-4-phenyl-3,5,10-trioxa-tricyclo[6.2.1.0 $\left.{ }^{2,6}\right]$ undecan-9-one (34). In a $200 \mathrm{~mL}$ round-bottom flask fitted with a stirring bar, reflux condenser, Dean-Stark trap, and argon inlet, A mixture of quinic acid $\mathbf{1}(5.0 \mathrm{~g}, 26.1 \mathrm{mmol})$, p-totuenesulfonic acid monohydrate $(0.2 \mathrm{~g})$, benzaldehyde $(4 \mathrm{~mL}, 39 \mathrm{mMol})$, and benzene $(100 \mathrm{~mL})$ was heated to reflux for overnight. The reaction mixture was cooled down, and solvent was removed under reduced pressure. Residue was purified by flash column with solvent mixture of Hex : $\operatorname{EtOAc}(1 / 1, \mathrm{v} / \mathrm{v})$. Collected product 34 as oil that solidified on standing, $6.2 \mathrm{~g}(91 \%$ yield). $\mathrm{R}_{\mathrm{f}}=0.2$ (EtoAC: $\left.\mathrm{Hex}=1: 1\right)$. MS: $[\mathrm{M}+\mathrm{Na}]^{+}=285 .{ }^{1} \mathrm{H} \mathrm{NMR}\left(\mathrm{CDCl}_{3}\right) \delta 2.42-2.53$ (m, $4 \mathrm{H}), 2.82(\mathrm{~d}, \mathrm{~J}=12.0 \mathrm{~Hz}, 1 \mathrm{H}), 4.40-4.43(\mathrm{~m}, 1 \mathrm{H}), 4.55-4.60(\mathrm{~m}, 1 \mathrm{H}), 4.84-4.87(\mathrm{~m}$, $1 \mathrm{H}), 5.79(\mathrm{~s}, 1 \mathrm{H}), 7.40-7.53(\mathrm{~m}, 5 \mathrm{H})$.

Benzoic acid 3-bromo-1-hydroxy-7-oxo-6-oxa-bicyclo[3.2.1]oct-4-yl ester (35). In a $200 \mathrm{~mL}$ round-bottom flask fitted with a stirring bar, reflux condenser, and argon 
inlet, A mixture of compound $34(2.0 \mathrm{~g}, 7.63 \mathrm{mmol})$, NBS (1.42g, $7.98 \mathrm{mmol})$, AIBN $(0.01 \mathrm{~g})$, and benzene $(120 \mathrm{~mL})$ was heated to reflux for $1 \mathrm{hr}$ under argon. The reaction mixture was cooled down, and solvent was removed under reduced pressure. Residue was dissolved in EtOAc, washed with saturated $\mathrm{NaHCO}_{3}$ aqueous solution, collected organic phase. Rough compound was purified by flash column with solvent mixture of $\mathrm{CH}_{2} \mathrm{Cl}_{2}$ : EtOAc $(98 / 2, \mathrm{v} / \mathrm{v})$. Collected product 35 as white solid, $2.2 \mathrm{~g}\left(85 \%\right.$ yield). $\mathrm{R}_{\mathrm{f}}=0.4$ (EtOAc: $\left.\mathrm{CH}_{2} \mathrm{Cl}_{2}=2: 98\right)$. MS: $[\mathrm{M}+\mathrm{Na}]^{+}=363 .{ }^{1} \mathrm{H} \mathrm{NMR}\left(\mathrm{CDCl}_{3}\right) \delta 2.22-2.63(\mathrm{~m}, 3 \mathrm{H}), 2.77-$ 2.85(m, 2H), $4.50(\mathrm{~d}, \mathrm{~J}=6.6,1 \mathrm{H}), 5.03-5.07(\mathrm{~m}, 1 \mathrm{H}), 5.70(\mathrm{~s}, 1 \mathrm{H}), 7.48-7.54(\mathrm{~m}, 2 \mathrm{H})$, 7.63-7.68 (m, 1H), $8.03(\mathrm{~d}, \mathrm{~J}=9.0 \mathrm{~Hz}, 2 \mathrm{H})$.

Benzoic acid 1-(tert-butyl-dimethyl-silanyloxy)-7-oxo-6-oxa-bicyclo[3.2.1]oct2-en-4-yl ester (36). In a $100 \mathrm{~mL}$ round-bottom flask fitted with a stirring bar, reflux condenser, and argon inlet, A mixture of compound 35 (1.85g, $5.44 \mathrm{mmol})$, DBU (2.4 $\mathrm{mL}, 16.1 \mathrm{mmol})$, tert-butyldimethylsilyl chloride $(1.12 \mathrm{~g}, 7.43 \mathrm{mmol})$, and acetonitrile $(50 \mathrm{~mL})$ was heated to reflux for overnight under argon. The reaction mixture was cooled down, and solvent was removed under reduced pressure. Residue was purified by flash column. Collected product 36 as white solid, $1.42 \mathrm{~g}\left(70 \%\right.$ yield). MS: $[\mathrm{M}+\mathrm{Na}]^{+}=397$. ${ }^{1} \mathrm{H}$ $\operatorname{NMR}\left(\mathrm{CDCl}_{3}\right) \delta 0.19(\mathrm{~s}, 3 \mathrm{H}), 0.23(\mathrm{~s}, 3 \mathrm{H}), 0.95(\mathrm{~s}, 9 \mathrm{H}), 2.42(\mathrm{~d}, \mathrm{~J}=11.0,1 \mathrm{H}), 2.50-2.54$ $(\mathrm{m}, 1 \mathrm{H}), 4.84(\mathrm{t}, \mathrm{J}=2.5 \mathrm{~Hz}, 1 \mathrm{H}), 5.52(\mathrm{t}, \mathrm{J}=1.8 \mathrm{~Hz}, 1 \mathrm{H}), 5.86(\mathrm{dt}, \mathrm{J}=10.0,1.8 \mathrm{~Hz}, 1 \mathrm{H})$, 6.29 (d, J=10.0 Hz, 1H), 7.48 (t, J=7.5 Hz, 2H), $7.62(\mathrm{t}, \mathrm{J}=7.5 \mathrm{~Hz}, 1 \mathrm{H}), 8.05(\mathrm{~d}, \mathrm{~J}=7.5 \mathrm{~Hz}$, $2 \mathrm{H})$.

\section{1-(tert-Butyl-dimethyl-silanyloxy)-4,5-dihydroxy-cyclohex-2-enecarboxylic} acid propylamide (37). In a $50 \mathrm{~mL}$ round-bottom flask fitted with a stirring bar, reflux condenser, and argon inlet, A mixture of compound $36(1.30 \mathrm{~g}, 3.48 \mathrm{mmol})$, and propylamine $(2.60 \mathrm{~mL}, 1.85 \mathrm{~g}, 31.28 \mathrm{mmol})$ were combined, then glacial acetic acid $(0.60$ $\mathrm{mL}, 0.63 \mathrm{~g}, 10.43 \mathrm{mmol}$ ) was added. The solution was warmed to $85^{\circ} \mathrm{C}$ in oil bath for 60 min under argon. The reaction mixture was cooled down, and solvent was removed under reduced pressure. Residue was purified by flash column with solvent EtOAc: Hex $=4: 1$. Collected product 37 as white solid, $0.52 \mathrm{~g}\left(45 \%\right.$ yield). MS: $[\mathrm{M}+\mathrm{H}]^{+}=330$. $\mathrm{R}_{\mathrm{f}}=0.17$ (EtOAc: Hex=4:1). ${ }^{1} \mathrm{H}$ NMR (DMSO) $\delta 0.05(\mathrm{~s}, 3 \mathrm{H}), 0.07(\mathrm{~s}, 3 \mathrm{H}), 0.82(\mathrm{t}, \mathrm{J}=7.5$ $\mathrm{Hz}, 3 \mathrm{H}), 0.85(\mathrm{~s}, 9 \mathrm{H}), 1.37-1.47$ (m, 2H), $1.69(\mathrm{t}, \mathrm{J}=12.6,1 \mathrm{H}), 1.85-1.91(\mathrm{~m}, 1 \mathrm{H}), 2.96-$ 3.12(m, 2H), 3.57-3.65 (m, 1H), $3.75-3.79(\mathrm{~m}, 1 \mathrm{H}), 4.92(\mathrm{~d}, \mathrm{~J}=4.8 \mathrm{~Hz}, 1 \mathrm{H}), 5.07(\mathrm{~d}$, $\mathrm{J}=4.8 \mathrm{~Hz}, 1 \mathrm{H}), 5.56(\mathrm{~d}, \mathrm{~J}=10.0 \mathrm{~Hz}, 1 \mathrm{H}), 5.69(\mathrm{dd}, \mathrm{J}=10.0,1.8 \mathrm{~Hz}, 1 \mathrm{H}), 7.21(\mathrm{t}, \mathrm{J}=3.0 \mathrm{~Hz}$, $1 \mathrm{H})$.

1,4,5-Trihydroxy-cyclohex-2-enecarboxylic acid propylamide (38). In a 100 $\mathrm{mL}$ round-bottom flask fitted with a stirring bar, compound $37(0.42 \mathrm{~g}, 1.28 \mathrm{mmol})$ was dissolved in $50 \mathrm{~mL}$ THF under ice bath, then $1 \mathrm{M}$ solution of TBAF $(2.0 \mathrm{~mL}, 2.0 \mathrm{mmol})$ was added. The solution was stirred for $1 \mathrm{hr}$ at $\mathrm{rt}$. The solvent was removed under reduced pressure. Residue was dissolved in methanol, the solution went through DOWEX 50W *8-200 strongly acidic cation exchanger column to remove TBAF. Product was further purified by flash column with solvent $\mathrm{CH}_{2} \mathrm{Cl}_{2}: \mathrm{MeOH}=96: 4$. Collected product 38, $0.15 \mathrm{~g}$ (50\% yield). $\mathrm{MS}:[\mathrm{M}+\mathrm{Na}]^{+}=238 . \mathrm{R}_{\mathrm{f}}=0.15\left(\mathrm{CH}_{2} \mathrm{Cl}_{2}: \mathrm{MeOH}\right.$ =96:4). ${ }^{1} \mathrm{H}$ NMR (DMSO) $\delta 0.81(\mathrm{t}, \mathrm{J}=7.5 \mathrm{~Hz}, 3 \mathrm{H}), 1.37-1.45(\mathrm{~m}, 2 \mathrm{H}), 1.69-1.72(\mathrm{~m}$, $1 \mathrm{H}), 1.87(\mathrm{t}, \mathrm{J}=12.3,1 \mathrm{H}), 2.96-3.05(\mathrm{~m}, 2 \mathrm{H}), 3.57-3.65(\mathrm{~m}, 1 \mathrm{H}), 3.73-3.79(\mathrm{~m}, 1 \mathrm{H}), 4.8$ 
$(\mathrm{d}, \mathrm{J}=6.1 \mathrm{~Hz}, 1 \mathrm{H}), 5.0(\mathrm{~d}, \mathrm{~J}=4.8 \mathrm{~Hz}, 1 \mathrm{H}), 5.37(\mathrm{dt}, \mathrm{J}=10.0,1.8 \mathrm{~Hz}, 1 \mathrm{H}), 5.61(\mathrm{~d}, \mathrm{~J}=1.8 \mathrm{~Hz}$, $1 \mathrm{H}), 5.64(\mathrm{~s}, 1 \mathrm{H}), 7.78(\mathrm{t}, \mathrm{J}=6.0 \mathrm{~Hz}, 1 \mathrm{H})$. Anal. $\left(\mathrm{C}_{10} \mathrm{H}_{17} \mathrm{NO}_{4} .0 .5 \mathrm{H}_{2} \mathrm{O}\right)$ calculated: $\mathrm{C}, 53.56$; H, 8.09; N, 6.25. Found: C, 53.75; H, 8.17; N, 5.93.

\subsubsection{Biology}

All chemicals and solvents were purchased from Sigma Aldrich Chemical Co. (St. Louis, MO) if not specified, and were used without any further purification. TNF-alpha was purchased from Invitrogen (Carlsbad, CA). Great EscAPe SEAP Chemilumi Kit was purchase from Clontech Lab, Inc. (Mountain View, CA).

\subsubsection{A549SN cell line and culture}

A549 cells (ATCC), which are a human lung adenocarcinoma cell line representative of alveolar type II epithelium, were maintained in a $5 \% \mathrm{CO}_{2}$ incubator at $37^{\circ} \mathrm{C}$ using BME (Cellgrow) supplemented with $10 \%$ heat-inactivated fetal calf serum, $2 \mathrm{mM}$ L-glutamine (Gibco), $100 \mathrm{U} / \mathrm{mL}$ penicillin- $100 \mu \mathrm{g} / \mathrm{mL}$ streptomycin (Gibco). The

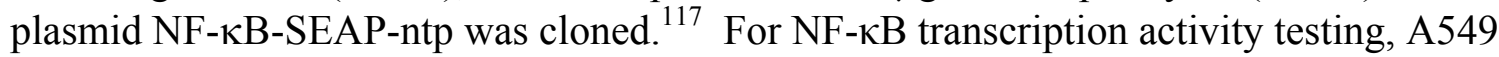
cells were transfected with NF-kB-SEAP-ntp plasmid, this is the A549SN cell line.

\subsubsection{NF- $\kappa B$ activity - A549SN cell SEAP method}

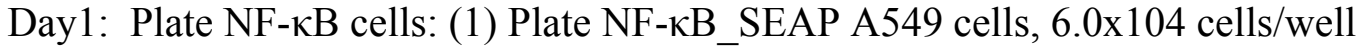
in three 24 well plates, $1000 \mu \mathrm{L}$ DMEM complete medium: 10\% heat inactivated FBS, $2 \mathrm{mM} \mathrm{L}-\mathrm{Glu}, 100 \mathrm{U} / \mathrm{mL}$ or $100 \mu \mathrm{g} / \mathrm{mL}$ Penn/Strep, $500 \mu \mathrm{g} / \mathrm{mL}$ G418. (2) Incubate at $37^{\circ} \mathrm{C}$ incubator with $5 \% \mathrm{CO}_{2}$. Day2 : Treat cells with drugs: Cells are all alive, not confluent ( 25-40\%). Treat cells with QA $=1 \mu \mathrm{M}$, or other compounds @ $1 \mu \mathrm{M}(990 \mu \mathrm{L} 1 \%$ FBS DMEM + $10 \mu 1$ (10/500) PBS diluted compounds from $5 \mathrm{mM}$ in DMSO), $+10 \mathrm{ng} / \mathrm{mL}$ TNFa, for 24 hrs. Day 3: Measure SEAP activity: $24 \mathrm{~h}$ later, take out 50 $\mu \mathrm{L}$ medium. Store at $-20^{\circ} \mathrm{C}$. Use Clontech "Great EscAPe SEAP Chemiluminescence Detection Kit" (Cat\# K2041-1) to measure luminescence through microplate luninometer (Packard $\alpha \mathrm{HT}$

microplate reader). Measure 1 second for once at RT. Cells left in plate were lysed in 250 $\mu \mathrm{l}$ lysis buffer $\left(10 \mathrm{mMK}_{2} \mathrm{HPO}_{4} ; 1 \mathrm{mMKH}_{2} \mathrm{PO}_{4} ; 1 \%\right.$ Triton X100; $\left.1 \mathrm{mMDTT}\right)$ for protein quantification (Pierce BCA Protein Assay Kit, Microplate Procedure) and SEAP activity was normalized to the total protein content.

\subsubsection{Anti-oxidant activity test method}

The DPPH and all standard antioxidant compounds including trolox were dissolved in 50\% acetone. The DPPH stock solution at a concentration of $0.625 \mathrm{mM}$ was prepared monthly and kept at $4{ }^{\circ} \mathrm{C}$ in dark. The $0.208 \mathrm{mM}$ fresh DPPH working solution was made daily by further diluting the stock solution in $50 \%$ acetone for each test. Stock 
solutions of CA, CGA, AA and compound 3 were prepared in 50\% acetone at concentrations of $10 \mathrm{mM}$, respectively, and stored at $4^{\circ} \mathrm{C}$. A series of working solutions were made by appropriate dilutions of the above standard phenolic acid stock solutions with $50 \%$ acetone.

\subsubsection{Conventional colorimetric analysis}

The conventional colorimetric DPPH scavenging capacity assay was performed according to a previously described laboratory protocol. ${ }^{116}$ Briefly, an aliquot of $500 \mu \mathrm{L}$ of different concentrations of sample extracts in $50 \%$ acetone was added to $500 \mu \mathrm{L}$ of $0.208 \mathrm{mM}$ DPPH solution. The initial concentration was $0.104 \mathrm{mM}$ for DPPH in all reaction mixtures. Each mixture was vortexed for a few seconds and test immediately. The absorbance $(A)$ of each reaction mixture at $515 \mathrm{~nm}$ was measured against a blank of $50 \%$ acetone using a UV-visible spectrometer. The level of DPPH remaining for each reaction time was calculated as: \% DPPH remaining=(A sample-t $\left./ \mathrm{A}_{\text {control }}\right) \times 100$. 


\section{CHAPTER 4. DETERMINATION OF QUINIC ACID AMIDES IN RAT PLASMA BY LC/MS/MS WITH A HYDROPHILIC INTERACTION LIQUID CHROMATOGRAPHY COLUMN}

\subsection{Introduction}

The interest in development of natural sources of anti-inflammatory activity has exploded in recent years. Quinic acid (QA) is a natural compound found widely in plants. Recently, QA has been identified as an active inflammatory ingredient in hot water extracts of the herbal Cat's claw (e.g., C-MED-100 ${ }^{\circledR}$ ), and shown to enhance immune cell response and DNA repair in humans. ${ }^{3-5}$ Unfortunately, QA is utilized by gastrointestinal bacteria as a carbon source for aromatic acid synthesis. Consequently, only a small fraction of QA is absorbed after oral administration of QA. ${ }^{27}$ Our group has focused on the discovery and development of stable QA derivatives. We have identified water soluble QA amide KZ-41(Compound 3) which possess potent anti-inflammatory activity. ${ }^{118,119}$ To study the pre-clinical pharmacokinetic properties of KZ-41, an analytical method is required for determination of the concentration of KZ-41 in preclinical samples.

There is no determination method of quinic acid amides, such as KZ-41 in the literature. Several methods of determination of QA in plants and food have been described. ${ }^{125-127}$ The reverse phase column $\left(\mathrm{C}_{18}\right.$ or $\left.\mathrm{C}_{8}\right)$ were used in the HPLC methods reported. Because QA is water soluble, the mobile phase used in RP column consisted of very high percentage of water, and re-equilibrated with $99 \% \mathrm{ACN}$ in actually

application. ${ }^{125}$ Both QA and KZ-41 are water soluble and high polar. The determination of polar compounds in biological fluids is very efficient by using hydrophilic interaction liquid chromatography-tandem mass spectrometry (HILIC-MS/MS) method. ${ }^{128-130}$ The advantages of ESI-MS detection in conjunction with HILIC mode separations are obvious: better separation with high organic phase and high sensitivity. ${ }^{131,132} \mathrm{UV}$ detection could be much simpler, but the sensitivity for QA and KZ-41 were worse due to their lack of UV absorption function group.

This chapter has developed and validated a rapid, robust and sensitive HILICMSMS method which employs protein precipitation for the quantitative analysis of QA amide KZ-41 in rat plasma. It has lower limit of quantitation (LLOQ) of $0.5 \mathrm{ng} / \mathrm{mL}$.

\subsection{Experimental}

\subsubsection{Material and Reagents Synthesis of Quinic Acid Amides}

KZ-41 and internal standard (IS) (Figure 4-1) were synthesized in our medicinal chemistry Lab. Methanol, acetonitrile, acetone, and water (HPLC grade), were purchased from Sigma-Aldrich (St Louis, MO, USA) and the other chemicals were of HPLC grade 


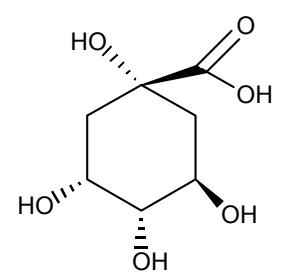

Quinic Acid, MW 192

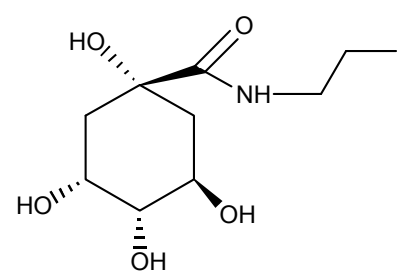

KZ-41, MW 232

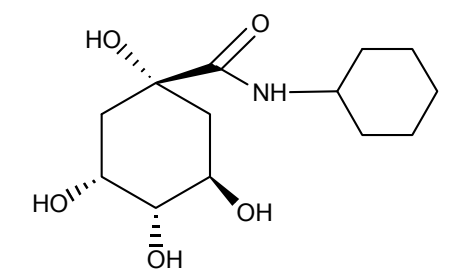

Internal Standard, MW 273

Figure 4-1. Chemical structure of quinic acid, KZ-41 and IS. 
or the highest quality available. Drug-free rat plasma were obtained from Pelfreez Biologicals (Rogers, AR, USA).

4.2.2 Preparation of Calibration Standards and Quality Control Samples Biology Testing of Quinic Acid Amides

KZ-41 stock solution $(1 \mathrm{mg} / \mathrm{mL})$ was prepared in acetonitrile. Serial working standard solutions of KZ-41 were prepared by further diluting each primary solution with acetonitrile to obtain desired concentrations. The drug-free rat plasma was spiked with KZ-41 and IS solution, and protein precipitated to prepare rat plasma solution.

The nominal rat plasma calibration standards of KZ-41 $(0.5,1.0,5.0,10.0,50.0,100.0$, and $500.0 \mathrm{ng} / \mathrm{mL}$ ) were prepared as above. The quality control samples were chosen at concentration levels $(5.0,25.0$, and $125.0 \mathrm{ng} / \mathrm{mL})$.

An IS stock solution $(1 \mathrm{mg} / \mathrm{mL})$ was prepared in methanol. The IS working solution was diluted with methanol to a final concentration of $10 \mathrm{ng} / \mathrm{mL}$. All solutions were stored at $-20^{\circ} \mathrm{C}$.

\subsubsection{Sample Processing}

Rat plasma samples were processed by protein precipitation. A $50 \mu 1$ volume of plasma sample was diluted with $150 \mu \mathrm{l}$ of methanol with IS $(10 \mathrm{ng} / \mathrm{mL})$. The samples were vortexed vigorously for $5 \mathrm{~min}$, refrigerated sample for $2 \mathrm{hrs}$, and the mixture was centrifuged for $15 \mathrm{~min}$ at $10000 \mathrm{~g}$. Supernatant aliquots of $100 \mu \mathrm{l}$ were transferred to vials and evaporated to dry by TurboVap LV concentration workstation (Caliper Life sciences, Hopkinton, MA) at $30^{\circ} \mathrm{C}$ under nitrogen. The residues were reconstituted to 200 $\mu \mathrm{l}$ with pure acetonitrile and vortex-mixed for $2 \mathrm{~min}$. Aliquot of $20 \mu \mathrm{l}$ was injected into LC-MS/MS for analysis.

\subsubsection{Instrumentation}

\subsubsection{Chromatographic conditions}

Chromatographic separation of analyte was carried out using Shimadzu (Columbia, MD) LC-10ADvp pumps with a Leap (Carrboro, NC) CTC PAL autosampler. The separation was performed on a PolyHYDROXYETHYL $A^{\mathrm{TM}}$ HILIC column $(5 \mu \mathrm{m}$, $100 \times 2.1 \mathrm{~mm}, 100 \AA$, The Nest Group, Inc., South borough, MA, USA). The mobile phase consisted of eluent $A$ (water) and eluent $B$ (acetonitrile), and separation achieved using a gradient program of 0 min: $15 \% \mathrm{~A} ; 4 \mathrm{~min}: 40 \% \mathrm{~A} ; 4.5 \mathrm{~min}: 15 \% \mathrm{~A}$, and the total analytical run time was $5.5 \mathrm{~min}$. The flow rate was $0.2 \mathrm{~mL} / \mathrm{min}$ with the column at ambient temperature. 


\subsubsection{Mass spectrometric conditions}

An API 4000 Q TRAP mass spectrometer equipped with an electrospray ion source (Applied Biosystems Sciex, Foster city, CA) operated in negative-ion mode was used for MS detection. Quantitation was performed using MRM mode to study parent $\rightarrow$ product ion transitions for KZ-41 (232 $\rightarrow$ 178) and IS $(272 \rightarrow 218)$ with unit resolution. Source dependent parameters optimized were gas 1 (nebulizer gas): 30 psi, gas 2 (heater gas): 40 psi, ion spray voltage (ISV): $-4500 \mathrm{~V}$, temperature [(transmission electron microscope (TEM)]: $700^{\circ} \mathrm{C}$. Compound dependent parameters were declustering potential (DP), entrance potential (EP), collision energy (CE), cell exit potential (CXP). DP: $-50 \mathrm{~V}$, CE: $-28 \mathrm{~V}$, EP: $-10 \mathrm{~V}$, CXP: $-15 \mathrm{~V}$ were set for KZ-41, and DP: $-60 \mathrm{~V}$, CE: 32 V, EP: -10 V,CXP: $-15 \mathrm{~V}$ were set for IS. Focusing potential (FP) was $400 \mathrm{~V}$ for both analyte and IS. Nitrogen was used as collision-activated dissociation (CAD) gas and was set at 6 psi. Quadrupole 1 and quadrupole 3 were maintained at unit resolution and dwell time was set at $250 \mathrm{~ms}$.

\subsubsection{Data processing and quantification}

Mass spectrometric data acquisition and data analysis were done with the Analyst Version 1.5. Software (Applied Biosystems). A weighted $1 / x$ linear regression was used to generate calibration curve from standards and calculate the concentrations of quality control and unknown samples. Equation of the standard curve: $y=m x+b$, where ' $y$ ' is the peak area ratio of the analyte to IS, ' $x$ ' is the theoretical concentration of the analyte divided by the theoretical concentration of IS, ' $m$ ' is the slope and ' $b$ ' is the intercept of the regression line.

\subsubsection{Method Validation}

\subsubsection{Linearity, accuracy and precision}

Rat plasma calibration standards were analyzed in three separate analytical runs. The peak areas generated by KZ-41 and IS were used to calculate their area ratios. The calibration curves were plotted by weighted $1 / x$ linear regression analysis of concentrations of KZ-41 versus the peak ratios of KZ-41 and IS.

The intra-batch precision and accuracy were assessed by determinations of KZ-41 in rat plasma at nominal concentrations of 5.0, 25.0, and $125.0 \mathrm{ng} / \mathrm{mL}$, on the same day. The inter-batch precision and accuracy were carried out by analyzing the same samples on three different days. Five replicates of each sample were analyzed together with a set of calibration standards, independently prepared from the control samples, in five analytical runs. The CV (\%) values of measured concentrations were used to show the precision of the method. The deviation of the mean measured concentrations away from the corresponding nominal concentration served as a measure of accuracy. 


\subsubsection{Matrix effect and recovery}

Matrix effect and recovery were evaluated according to a published literature. ${ }^{133}$ Briefly, matrix effect was determined by comparing the analytical response of the standards spiked into plasma extracts (Solution B) with that of the net standard solutions (Solution A). The loss of signal represents the ion suppression. The extraction recovery of KZ-41 from rat plasma was determined by comparing the analytical response of processed quality control samples (Solution C) with that of blank net plasma extracts spiked with standard working solutions (Solution $\mathrm{B}$ ). They are expressed as: matrix effect $(\mathrm{ME} \%)=(\mathrm{B} / \mathrm{A}) * 100$; recovery rate $(\mathrm{RR} \%)=(\mathrm{C} / \mathrm{B}) * 100$. These experiments were performed in triplicate at concentration level $5.0,25.0$, and $125.0 \mathrm{ng} / \mathrm{mL}$.

\subsubsection{Stability}

Storage stability tests were performed with quality control (QC) samples subjected to different storage conditions $\left(4^{\circ} \mathrm{C}\right.$ or at $25^{\circ} \mathrm{C}$ for $\left.48 \mathrm{~h}\right)$. The stability was calculated by comparing injected freshly prepared QC samples with re-injected samples $48 \mathrm{~h}$ later. Five replicates were analyzed with each sample at each concentration. Three concentration levels $(5.0,25.0$ and $125.0 \mathrm{ng} / \mathrm{mL})$ were studied. The storage stability of both KZ-41 and IS in the working solution and in the processed extracts was investigated.

\subsection{Results and Discussion}

\subsubsection{Optimization of Sample Preparation Procedure}

Protein precipitation is a valid and fast rat plasma sample preparation procedure. The commonly used solvent is acetonitrile. We started with acetonitrile as plasma splash solvent ( $150 \mu \mathrm{l}$ organic solvent into $50 \mu \mathrm{l}$ plasma), the recovery rate was poor. Then other organic solvents (methanol, acetone, and chloroform) were tested. We found methanol provided a good protein precipitation and drug extraction recovery. Methanol was selected as plasma splash organic solvent.

\subsubsection{Optimization of Chromatography Condition}

Good chromatography separation with sharp peak shape will ensure high selectivity, specificity and sensitivity of the analytical method. This optimization will be achieved by good matching within analyte, column, and mobile phases. KZ-41 is an amide, neutral in acidity, and water soluble $(\log \mathrm{P}=-2.03)$. We tested it on a $\mathrm{C}_{8}$ reversephase symmetry $(3.5 \mu \mathrm{m}, 2.1 \times 50 \mathrm{~mm}, 100 \AA)$ column, $95 \%$ aqueous phase in mobile phase was needed to obtain 2 min retention time, and the peak shape was distorted. Furthermore, too much aqueous reduce the sensitivity of MS detection, and the stability of the $\mathrm{C}_{8}$ column. When KZ-41 was separated on a PolyHYDROXYETHYL $\mathrm{A}^{\mathrm{TM}}$ HILIC 
column $(5 \mu \mathrm{M}, 100 \times 2.1 \mathrm{~mm}, 100 \AA$, The Nest Group, Inc., Southborough, MA, USA), with $85 \%$ acetonitrile in mobile phase (acetonitrile and water), this amide had about 3 min retention time with good peak shape (Figure 4-2). The higher percentage of organic phase improved the sensitivity of MS detection. Several compounds from KZ-41 chemical library were investigated to find a suitable IS, a structurally similar analog was found to be the most appropriate for this study. The structures of quinic acid, KZ-41, and IS were shown in Figure 4-1.

\subsubsection{Optimization of MS Instrumentation}

MS instrument parameters for determination each compound were optimized by directly infusion each compound $(1 \mu \mathrm{g} / \mathrm{mL}$ acetonitrile solution) into the mass spectrometer at a flow rate of $600 \mu \mathrm{l} / \mathrm{h}$. On the negative full scan mass spectra, the deprotonated molecular ions [M - H] $]^{-}$of KZ-41 and IS were observed at a mass to charge ratio $(\mathrm{m} / \mathrm{z})$ of 231.7 and 271.9 , respectively. The product ion scan resulted in a major fragment at $m / z 177.8$ for KZ-41 and $m / z 217.9$ for IS (Figure 4-3). The fragments were the products of parent molecules by lost three water molecules (mass $=18 * 3$ ). These MRM ion pair selections contributed to the compound specificity of the MS method. The $\mathrm{CE}$ and collision CXP were optimized in order to obtain the best product ion/precursor ion intensity ratio. The mass spectrometry detection MRM ion pairs for KZ-41 and IS were selected as 232/178 and 272/218 at unit resolution, respectively. Parameters including ionization voltage, focusing and DP, flow of curtain and nebulizer gas were further investigated in order to obtain the maximum intensity as a HILIC/MS/MS analysis method.

\subsubsection{Linearity, Accuracy and Precision}

A linear dynamic range was obtained over the concentration range from 0.5 to $500 \mathrm{ng} / \mathrm{mL}$ (Figure $4-4$ ). The standard curve equation is $\mathrm{y}=0.0059 \mathrm{x}+0.0154$. The correlation coefficient $\left(\mathrm{r}^{2}\right)$ is greater than 0.999 .

The intra- and inter-day accuracy and precision are presented in Table 4-1. The intra-day accuracy was $112.67 \%, 98.89 \%, 98.06 \%$ at concentrations of 5.0, 25.0, and $125.0 \mathrm{ng} / \mathrm{mL}$ respectively. They are all within the accepted deviation range $85 \%$ to $115 \%$. The CV (\%) value is also within accepted range.

\subsubsection{Specificity and Selectivity}

MRM chromatograms of blank, KZ-41, IS and QC samples were showed in Figure 4-2. LC/MS/MS system with MRM mode provides high selectivity and specificity. The LC separation selectivity and specificity was good, there was no peaks that co-eluted with either KZ-41 or the IS, and each analyte had specific retention time 

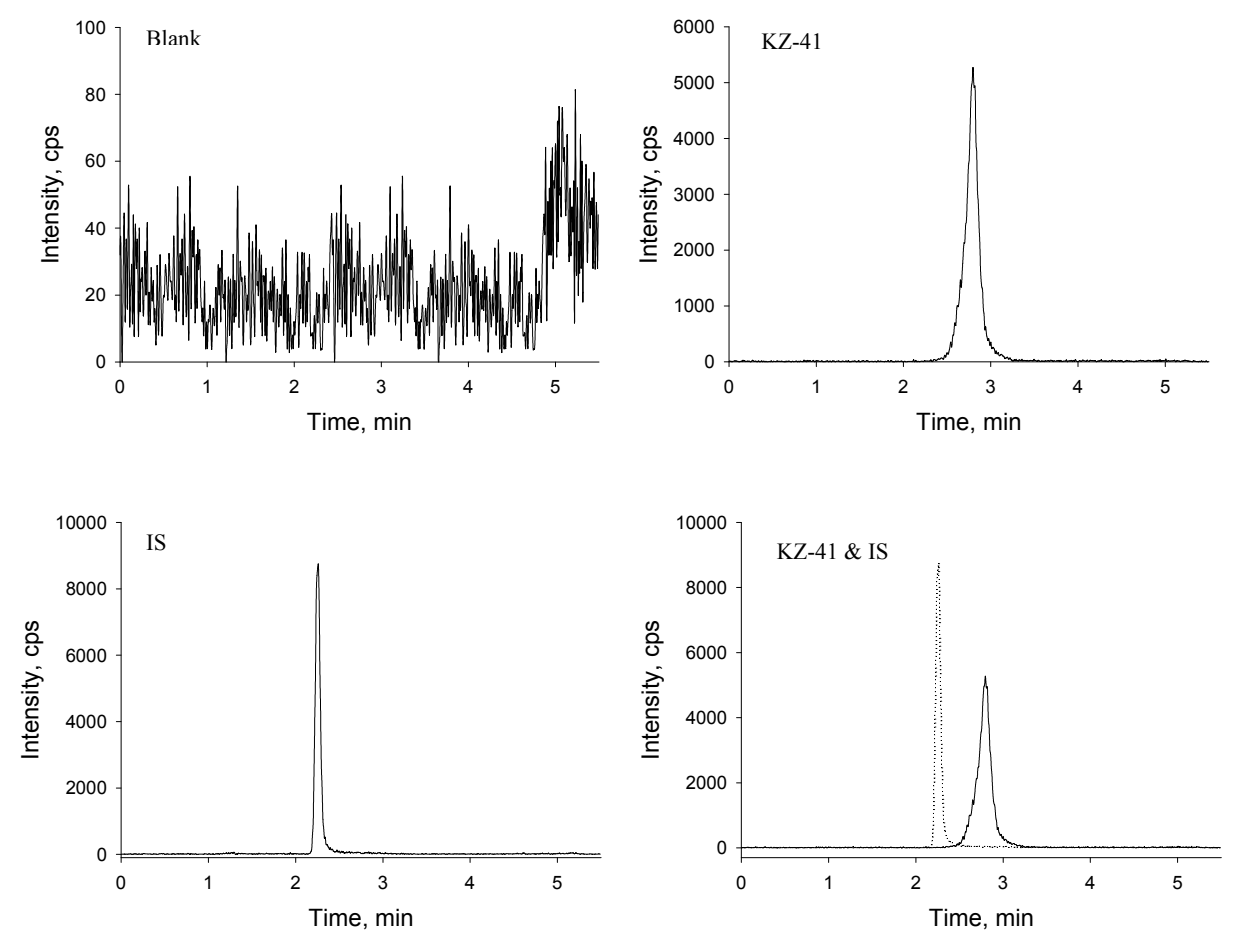

Figure 4-2. Representative HILIC-MS MRM chromatograms of KZ-41 and IS in extraction from rat plasma. The separation was performed on a PolyHYDROXYETHYL HILIC column with $85 \%$ acetonitrile in water as the mobile phase. The flow rate was 0.2 $\mathrm{mL} / \mathrm{min}$. Detection was performed using triple quad mass spectrometer in negative MRM mode. 

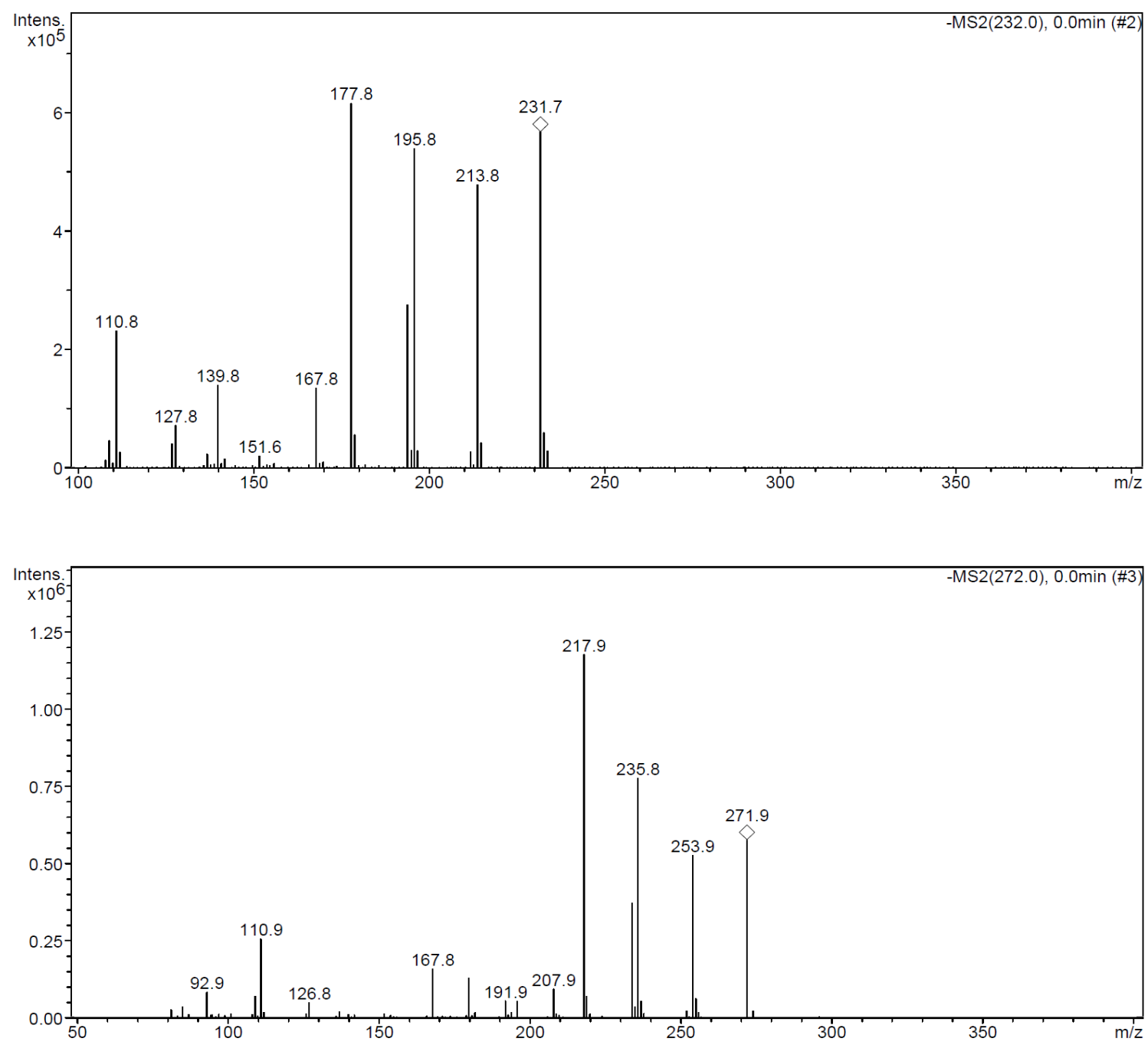

Figure 4-3. Product mass spectra of KZ-41 and IS. Upper spectrum. KZ-41, parent ion $[\mathrm{M}-\mathrm{H}]=232$, dominated daughter ions: $214,196,178$. Lower spectrum. IS, parent ion [M$\mathrm{H}]=272$, dominated daughter ions: 254, 236, 218. 


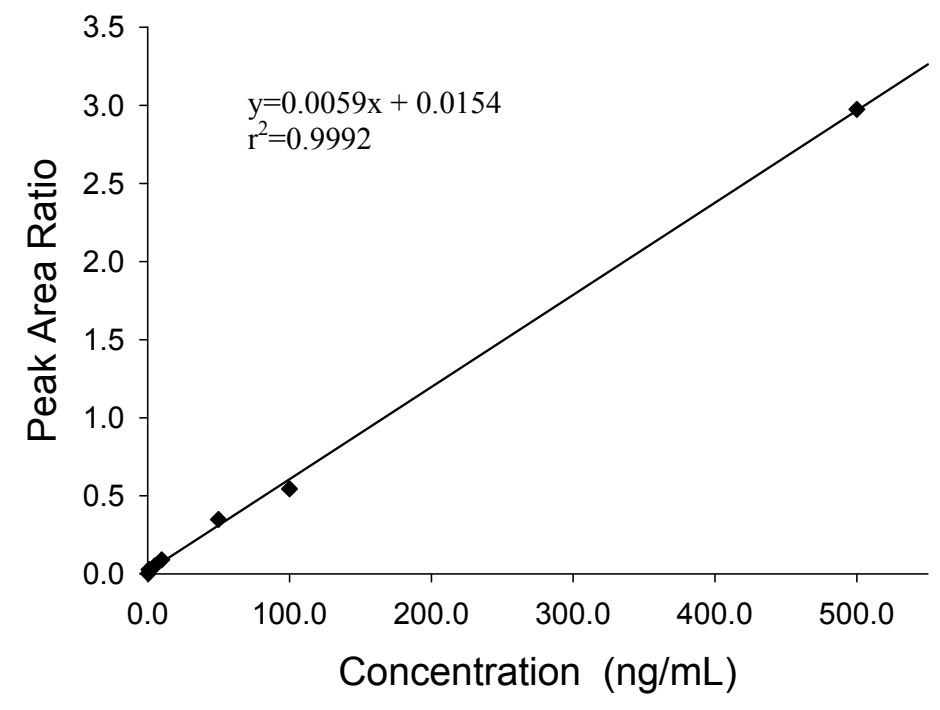

Figure 4-4. Representative standard curve of KZ-41 in rat plasma. The standard curve equation is $y=0.0059 x+0.0154$. The correlation coefficient $\left(r^{2}\right)$ is greater than 0.999 over the concentration range of 0.5 to $500 \mathrm{ng} / \mathrm{mL}$. 
Table 4-1. Intra- and inter-day accuracy and precision of KZ-41 in rat plasma.

\begin{tabular}{cccrr}
\hline Time & $\begin{array}{c}\text { Nominal } \\
\text { concentration } \\
(\mathrm{ng} / \mathrm{mL})\end{array}$ & $\begin{array}{c}\text { Found } \\
\text { concentration } \\
(\mathrm{ng} / \mathrm{mL})\end{array}$ & ${\text { Accuracy }(\%)^{\mathrm{a}}}^{\mathrm{a}}$ & $\mathrm{CV}(\%)^{\mathrm{b}}$ \\
\hline Intra-day $(\mathrm{n}=5)$ & 5.0 & 5.63 & 112.67 & 14.08 \\
& 25.0 & 24.72 & 98.89 & 5.38 \\
& 125.0 & 122.57 & 98.06 & 3.75 \\
Inter-day $(\mathrm{n}=3)$ & 5.0 & 5.36 & 107.20 & 11.20 \\
& 25.0 & 24.12 & 96.48 & 5.80 \\
& 125.0 & 123.15 & 98.52 & 3.30 \\
\hline
\end{tabular}

${ }^{a}$ Accuracy (\%) is calculated as mean found concentrations over nominal concentration $\mathrm{x}$ $100 \%$.

${ }^{\mathrm{b}} \mathrm{CV}(\%)$ is calculated as standard deviation of found concentrations over nominal concentration $\mathrm{x} 100 \%$. 
(Figure 4-2). MRM ion pairs were parent ions with moiety-specific fragment ions, there was no mass transition interference from rat plasma with either of the compounds.

\subsubsection{Matrix Effect and Recovery}

In this study, the values of matrix effect were $79.4 \%$ and $81.3 \%$ for KZ-41 and IS, respectively, which meant the biological matrix had similar effect on the ionization of KZ-41 and IS. Extraction recoveries for KZ-41 and the IS were 100.9\% and 99.2\%, respectively. Only a negligible carryover effect (about $0.1 \%$ ) was observed after injection of a blank plasma extract following injection of the upper calibration standard.

\subsubsection{Stability}

The result showed both KZ-41 and IS in the working solution and in the processed extracts were stable over $48 \mathrm{~h}$ storage $\left(4^{\circ} \mathrm{C}\right.$ or at $25^{\circ} \mathrm{C}$ for $\left.48 \mathrm{~h}\right)$. KZ-41 and IS did not show any significant degradation after protein plasma precipitation even after 48 $\mathrm{hr}$. This suggests that plasma protein precipitation can be conveniently performed within 2 days of the LC-MS/MS measurement analysis. In the freeze/thaw investigations and long-term stability experiments, the observed maximum degradation was within $20 \%$ and fulfilled the acceptance criteria.

\subsection{Conclusions}

A robust and sensitive HILIC-MS/MS method for the analysis of KZ-41 in rat plasma has been developed and validated. This assay used protein precipitation method for sample preparation, has a lower limit of detection of $0.5 \mathrm{ng} / \mathrm{mL}$. The standard curve equation is $y=0.0059 x+0.0154$. The correlation coefficient $\left(r^{2}\right)$ is greater than 0.999 over the concentration range of 0.5 to $500 \mathrm{ng} / \mathrm{mL}$. It is novel and useful for the pharmacokinetic studies of KZ-41. 


\section{CHAPTER 5. PHARMACOKENETICS AND BIOAVAILABILITY OF NOVEL ANTI-INFLAMMATORY AGENT KZ-41}

\subsection{Introduction}

Many interests have been raised in development of natural products or modified products having anti-inflammatory activity in recent years. Quinic acid (QA) is a natural compound found widely in plants. ${ }^{8-10}$ Recently, QA has been identified as an active ingredient in hot water extracts of the herbal Cat's claw (e.g., C-MED-100 ${ }^{\circledR}$ ), and shown to enhance immune cell response and DNA repair in humans. ${ }^{3-5}$ In particular, such extracts have been found to have various anti-inflammatory effects such as inhibition of the production of the inflammatory cytokine TNF $\alpha$, scavenges free radicals ${ }^{45}$ and the activation of the central transcription factor nuclear factor $\kappa \mathrm{B}(\mathrm{NF}-\kappa \mathrm{B}) .{ }^{46-49}$ Unfortunately, QA is utilized by microorganisms and plants through the shikimate biosynthetic pathway leading to aromatic amino acids phenylalanine, tyrosine, and tryptophan..$^{16,19,20,134,135}$ In 1967, a QA oxidizing enzyme produced by acetic acid bacteria was discovered demonstrating that bacteria could catabolize QA. ${ }^{25}$ Subsequently, the QA catabolic pathway was described as a result of characterization of fungal mutants with lesions in genes encoding biosynthetic shikimate pathway enzymes. ${ }^{26}$ Bacteria and fungi utilize QA as a growth substrate and thus express an abundance of the aforementioned enzymes involved in QA transformation. High levels of QA catabolizing enzymes in gut bacteria is consistent with the finding that less than $10 \%$ of an orally administered dose QA is recovered in rats. ${ }^{27}$

In short, rapid degradation by gut flora potentially limits the oral effectiveness of current quinic acid preparations. Our study group has focused to discover new antiinflammatory agents that will be orally active based on the quinic acid structure. We have identified water soluble QA amide KZ-41 which possess potent anti-inflammatory activity. ${ }^{118,119}$ There are no biopharmaceutical and pharmaceutics data available for this compound to establish the dosing for in vivo animal study. This study was conducted to investigate the bacterial stability, and absorption, distribution, metabolism and elimination of KZ-41 in rat after intravenous and oral administration.

\subsection{Experimental}

\subsubsection{Material and Reagents}

KZ-41 and internal standard (IS) were synthesized in our medicinal chemistry Lab. Methanol, acetonitrile, acetone, and water (HPLC grade), were purchased from Sigma-Aldrich (St Louis, MO, USA) and the other chemicals were of HPLC grade or the highest quality available. Drug-free rat plasma was obtained from Pelfreez Biologicals (Rogers, AR, USA). 


\subsubsection{Microsomal Stability}

Microsomal metabolic stability of KZ-41 was assessed in Pooled IGS SpragueDawley Rat Liver Microsomes (Xenotech, LLC, Lenexa, Kansas) preparations by monitoring disappearance of the parent compound over an incubation period of 90 minutes. The concentration change of intact parent compound in the samples was estimated by comparing analyte concentrations before and after incubation using LCMS/MS assay. The detailed procedure is described in the following. The stock solution ( $10 \mathrm{mM}$ stock in methanol) was diluted in PBS buffer (50 mM, pH 7.4) to make $500 \mu \mathrm{M}$ working solution. Test compounds were incubated at a final concentration of $5.0 \mu \mathrm{M}$. A concentration of $50.0 \mu \mathrm{M}$ was utilized to allow for detection of possible minor metabolites. Rat liver microsomes were utilized at a final concentration of $1.0 \mathrm{mg} / \mathrm{mL}$. Reactions mixture were prepared by adding $25 \mu 1$ of microsomal sprotein solution $(20 \mathrm{mg} / \mathrm{mL})$ to $50 \mu 1$ test compound $(500 \mu \mathrm{M})$ and $425 \mu 1$ of NADPH regenerating system (NRS) "master mix" solution. The combined components, with the exception of the microsomes, were preincubated at $37^{\circ} \mathrm{C}$ for $10 \mathrm{~min}$, after which the microsomes were added. The mixture was incubated in a water bath at $37^{\circ} \mathrm{C}$. Deactivated microsome solution was used as negative control. The NRS "master mix" is a solution of glucose 6phosphate dehydrogenase, $\mathrm{NADP}+, \mathrm{MgCl} 2$, and glucose 6-phosphate, prepared per manufacturer's instructions (BD Biosciences, Waltham, MA). Each $5.0 \mathrm{~mL}$ stock of NRS "master mix" solution contains $3.8 \mathrm{~mL}$ H20, $1.0 \mathrm{~mL}$ solution "A" (Cat. \#451220), and $0.2 \mathrm{~mL}$ solution "B" (Cat. \#451200).

At each time point ( 0,45 and 90 minutes), $100 \mu 1$ of reaction was removed and the reaction was terminated by addition of $100 \mu \mathrm{L}$ of acetonitrile containing internal standard IS $(150 \mathrm{ng} / \mathrm{mL})$. Samples were then centrifuged at 10,000 rpm for 10 minutes at $4^{\circ} \mathrm{C}$ to remove debris and precipitated protein. Approximately $150 \mu \mathrm{l}$ of supernatant was subsequently transferred to a new sample vial for analysis.

\subsubsection{Plasma Protein Binding}

Plasma protein binding of KZ-41 was determined by using rapid equilibrium dialysis. The RED device for rapid equilibrium dialysis was obtained from Pierce Biotechnology Inc (Rockford, IL). The experimental procedure was followed to the manual protocol with optimization. Briefly, biologically relevant concentrations of test compound were prepared (low, middle and high) in rat plasma. The RED inserts were placed in the base plate. $300 \mu \mathrm{L}$ of the plasma sample was placed in the sample chamber and $500 \mu \mathrm{L}$ of dialysis buffer, $\mathrm{pH} 7.4$ in the buffer chamber. The chambers were covered with a seal and incubated at $37^{\circ} \mathrm{C}$ for $4-6$ hours at approximately $100 \mathrm{rpm}$ on an orbital shaker. At the end of incubation, remove seal and confirm volume of the sample chamber. Minimal to no volume change should have occurred. Aliquots of plasma and buffer were used to determine the drug concentration using an LC-MS/MS assay. Pipette $50 \mu \mathrm{L}$ each of post-dialysis samples from the buffer and the plasma chambers into separate microcentrifuge tubes. Add $50 \mu \mathrm{L}$ of plasma to the buffer samples, and an equal volume of PBS to the collected plasma samples. Add $100 \mu \mathrm{L}$ of precipitation Methanol 
to precipitate protein and release compound. Vortex and incubate 30 minutes on ice. Centrifuge for 10 minutes at 13,000-15,000 $\times g$. Transfer supernatant to a vial, dry the supernatant under nitrogen, and reconstitute to $200 \mu \mathrm{L}$ with acetonitrile before $\mathrm{LC} / \mathrm{MS} / \mathrm{MS}$. Determine the concentration of test compound in the buffer and plasma chambers from peak areas relative to the internal standard. Calculate the percentage of the test compound bound as follows:

$\%$ Free $=($ Concentration buffer chamber/Concentration plasma chamber $) \times 100 \%$

$\%$ Bound $=100 \%$ - \% Free

\subsubsection{Bacterial Stability}

Bacteria Gluconobacter oxydans was selected to test the bacterial stability of QA analogs. $^{30,31}$ The log growth phase in which this bacterial strain has the most active growth, was obtained by plotting the growth curve of this bacterial. The growth curve of this bacteria strain was obtained by taking OD readings generally at $0,0.5,1,2,4,8,12$, and 24 hours when bacterial is cultured. Then plot the log OD versus time and find the linear portion of the graph which is the log growth phase of this bacterial. Gluconobacter oxydans was incubated in mannitol media at $26^{\circ} \mathrm{C}$ and $150 \mathrm{rpm}$, and used to test the stability of QA analogs when it was in the log growth phase. Test was divided into three groups: negative control (QA in autoclaved bacterial media), positive control (QA in active bacterial media), and treatment (KZ-41 in active bacterial media). Compounds were dissolved in fresh culture media. $200 \mu$ test solution $(2 \mathrm{mg} / \mathrm{mL})$ was added into 3 $\mathrm{mL}$ bacterial media in a 6 well plate. Samples were taken at different time points after treatment. Sampling procedure: removed $200 \mathrm{uL}$ sample from each well and put into labeled tubes, quenched sample with $300 \mathrm{uL}$ of methanol. Between samplings, plate was placed on C24 Incubator Shaker (New Brunswick Scientific, Edison, NJ) at $26^{\circ} \mathrm{C}$ and 150 rpm. Samples were store at $-80^{\circ} \mathrm{C}$ for future use.

\subsubsection{Pharmacokinetic Studies in Rats}

All animal procedures used in this research were approved by the University of Tennessee Animal Care and Use Committee. Pre-cannulated Sprague-Dawley male rats (200 -300 g, jugular vein alone for oral study and jugular vein and femoral vein for intravenous study) were obtained from Harlan Bioscience (Indianapolis, IN). Animals were fed a normal laboratory diet, allowed ad libitum access to water and maintained on a 12-hr light-dark cycle $\left(25^{\circ} \mathrm{C}\right)$. The catheter was exteriorized between the shoulder blades to ensure the catheter remains in place over the sampling interval. Catheter patency was maintained with heparin glycerol solution (100 IU heparin $/ \mathrm{mL}$ in $75 \%$ glycerol saline solution). Groups of animals $(\mathrm{n}=6)$ received a dose $(10 \mathrm{mg} / \mathrm{kg})$ of the compound of KZ41 via the oral or intravenous route. For oral administrations, the animals were fasted overnight and until $4 \mathrm{hr}$ after administration of test compound. Blood samples (200 to $300 \mathrm{uL}$ ) were withdrawn from the jugular vein catheter pre-dose and at regular intervals after dosing $(5,15,30,45$ minutes and 1, 2, 4, 8, 12, and $24 \mathrm{hrs})$. An equal volume of 
sterile saline solution will be administered via the jugular vein catheter after each blood collection. All experiments will be performed on un-restrained animals. A maximum of twelve blood samples, representing no more than $2 \%$ of the body weight in blood volume, were taken from individual animals. Blood was transferred into Microtainer ${ }^{\circledR}$ brand tubes with lithium heparin (BD, Franklin Lakes, NJ). Plasma was separated immediately by centrifugation (3000g for $2 \mathrm{~min}$ at $4^{\circ} \mathrm{C}$ ). Urine and fecal samples were pooled and collected up to $24 \mathrm{hr}$ respectively. All samples were stored at $-80^{\circ} \mathrm{C}$ until future analysis.

\subsubsection{Analytical Methods}

A LC-MS/MS method was developed to quantitate KZ-41 concentration in rat plasma. This method was validated and published separately. Chromatographic separation of analyte was carried out using Shimadzu (Columbia, MD) LC-10ADvp pumps with a Leap (Carrboro, NC) CTC PAL autosampler. The separation was performed on a PolyHYDROXYETHYL A ${ }^{\mathrm{TM}}$ HILIC column $(5 \mu \mathrm{M}, 100 \times 2.1 \mathrm{~mm}, 100$ $\AA$, The Nest Group, Inc., South borough, MA, USA). The mobile phase consisted of eluent $\mathrm{A}$ (water) and eluent $\mathrm{B}$ (acetonitrile), and separation achieved using a gradient program of 0 min: $15 \% \mathrm{~A} ; 4 \mathrm{~min}: 40 \% \mathrm{~A} ; 4.5 \mathrm{~min}: 15 \% \mathrm{~A}$, and the total analytical run time was $5.5 \mathrm{~min}$. The flow rate was $0.2 \mathrm{~mL} / \mathrm{min}$ with the column at ambient temperature. An API 4000 Q TRAP mass spectrometer equipped with an electrospray ion source (Applied Biosystems Sciex, Foster city, CA) operated in negative-ion mode was used for MS detection. Quantitation was performed using MRM mode to study parent $\rightarrow$ product ion transitions for KZ-41 $(232 \rightarrow 178)$ and IS $(272 \rightarrow 218)$ with unit resolution. Source dependent parameters optimized were gas 1 (nebuliser gas): 30 psi, gas 2 (heater gas): 40 psi, ion spray voltage (ISV): $-4500 \mathrm{~V}$, temperature [(transmission electron microscope (TEM)]: $700^{\circ} \mathrm{C}$. Compound dependent parameters were declustering potential (DP), entrance potential (EP), collision energy (CE), cell exit potential (CXP). DP: -50 V, CE: -28 V, EP: -10 V, CXP: -15 V were set for KZ-41, and DP: -60 V, CE: -32 V, EP: -10 V,CXP: $-15 \mathrm{~V}$ were set for IS. Focusing potential (FP) was $400 \mathrm{~V}$ for both analyte and IS. Nitrogen was used as collision-activated dissociation (CAD) gas and was set at 6 psi. Quadrupole 1 and quadrupole 3 were maintained at unit resolution and dwell time was set at $250 \mathrm{~ms}$.

Rat plasma samples were processed by protein precipitation. A $50 \mu \mathrm{l}$ volume of plasma sample was diluted with $150 \mu \mathrm{l}$ of methanol with IS $(10 \mathrm{ng} / \mathrm{mL})$. The samples were vortexed vigorously for $5 \mathrm{~min}$, refrigerated sample for $2 \mathrm{hrs}$, and the mixture was centrifuged for $15 \mathrm{~min}$ at $10000 \mathrm{~g}$. Supernatant aliquots of $100 \mu \mathrm{l}$ were transferred to vials and evaporated to dry by TurboVap LV concentration workstation (Caliper Life sciences, Hopkinton, MA) under nitrogen at $30^{\circ} \mathrm{C}$. The residues were reconstituted to 200 $\mu \mathrm{l}$ with pure acetonitrile and vortex-mixed for $2 \mathrm{~min}$. Aliquot of $20 \mu \mathrm{l}$ was injected into LC-MS/MS for analysis.

An aliquot, $600 \mu 1$, of the pooled urine was evaporated to dryness under nitrogen, $200 \mu \mathrm{l}$ of acetonitrile with IS $(10 \mathrm{ng} / \mathrm{mL})$ was added. Approximately $1.8 \mathrm{~g}$ of pooled fecal sample was extracted with $10 \mathrm{~mL}$ of methanol for $1 \mathrm{hr}$ in a polypropylene centrifuge tube 
using a rotating mixer. The extract was centrifuged at $4,000 \mathrm{~g}$ for $10 \mathrm{~min}$. The supernatant was transferred to a new tube. The pellet was re-extracted as described above and the supernatants were combined. The extract was evaporated to dryness under a stream of nitrogen, residue was dissolved in $0.5 \mathrm{~mL}$ methanol water mixture $(50 / 50 \mathrm{v} / \mathrm{v})$, and transferred into a $1.8 \mathrm{~mL}$ vial. This mixture was evaporated to dryness under nitrogen, and $200 \mu \mathrm{l}$ of acetonitrile with IS $(10 \mathrm{ng} / \mathrm{mL})$ was added. The samples were vortexed vigorously for $5 \mathrm{~min}$, and the mixture was centrifuged for $15 \mathrm{~min}$ at $10000 \mathrm{~g}$. Supernatant aliquots of $20 \mu \mathrm{l}$ was injected into LC-MS/MS for analysis.

\subsubsection{Pharmacokinetic Data Analysis}

Plasma concentration-time profiles were analyzed by non-compartmental analysis using WinNonlin 5.0.1 (Pharsight Corporation, Mountain View, CA). The maximum plasma concentration $\left(\mathrm{C}_{\max }\right)$ observed after oral dosing and the time at which it was observed $\left(\mathrm{T}_{\max }\right)$ were determined by direct inspection of the individual plasma concentration-time profiles. The terminal half-life $\left(\mathrm{t}_{1 / 2}\right)$ was calculated as 0.693 divided by the terminal phase rate constant $\lambda_{z}$. The area under the plasma concentration-time curve from time 0 to infinity $\left(\mathrm{AUC}_{\text {inf }}\right)$ was calculated by the trapezoidal rule with extrapolation to time infinity. The total plasma clearance (CL) of i.v. KZ-41 was calculated as the i.v. dose divided by the $\mathrm{AUC}_{\text {inf }}$ of i.v $\left(\mathrm{CL}=\mathrm{Dose}_{\mathrm{iv}} / \mathrm{AUC}_{\mathrm{inf}, \mathrm{iv}}\right)$. Volume of distribution based on terminal phase $(\mathrm{Vz})$ was calculated as the i.v. dose divided by the product of $\mathrm{AUC}_{\text {inf }}$ of i.v and $\lambda_{z}\left(\mathrm{Vz}=\operatorname{Dose}_{\mathrm{iv}} /\left(\lambda_{\mathrm{z}} * \mathrm{AUC}_{\mathrm{inf}, \mathrm{iv}}\right)\right)$. The parameters of oral dose were calculated same way as iv dose. The relative oral bioavailability $(\mathrm{F})$ was calculated as $\mathrm{F}=\left(\mathrm{AUC}_{\text {inf, oral }} * \operatorname{Dose}_{\text {iv }}\right) /\left(\mathrm{AUC}_{\text {inf, iv }} * \mathrm{Dose}_{\text {oral }}\right)$.

Statistical analyses were performed using a two-tailed t test at a 5\% level of significance.

\subsection{Results}

\subsubsection{Pharmacokinetics of KZ-41}

The structure of KZ-41 is shown in Figure 5-1. Figure 5-2 shows the plasma mean concentration - time profile of KZ-41 $(n=6)$ after administration of i.v. and oral doses at dose of $10 \mathrm{mg} / \mathrm{kg}$. The derived pharmacokinetic parameters is listed in Table $5-1$. The total plasma clearance of KZ-41 in rats was $13.8 \mathrm{~mL} / \mathrm{min} / \mathrm{kg}$ (i.v.), or 12.1 $\mathrm{mL} / \mathrm{min} / \mathrm{kg}$ (oral). This moderate clearance indicated the compound would have reasonable duration in the body. The terminal plasma elimination half-lives was 183 min, or $3.1 \mathrm{hr}$. The compound was moderately distributed in the body with volume of distribution of $3.65 \mathrm{~L} / \mathrm{kg}$. The amount of compound excreted unchanged into urine and feces was approximately $60 \%$ of the dose by both routes, this suggested low metabolism of KZ-41 in the rat body. The oral bioavailability of this compound in rat was about $111 \%$. Theoretically, Bioavailability should not exceed $100 \%$. The result which is over 


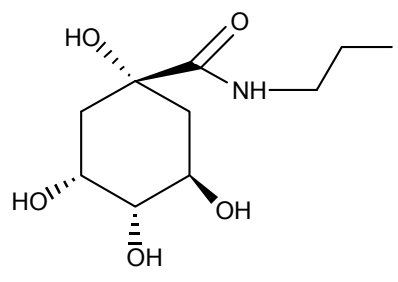

KZ-41, MW 232

Figure 5-1. Chemical structure of quinic acid amide KZ-41.

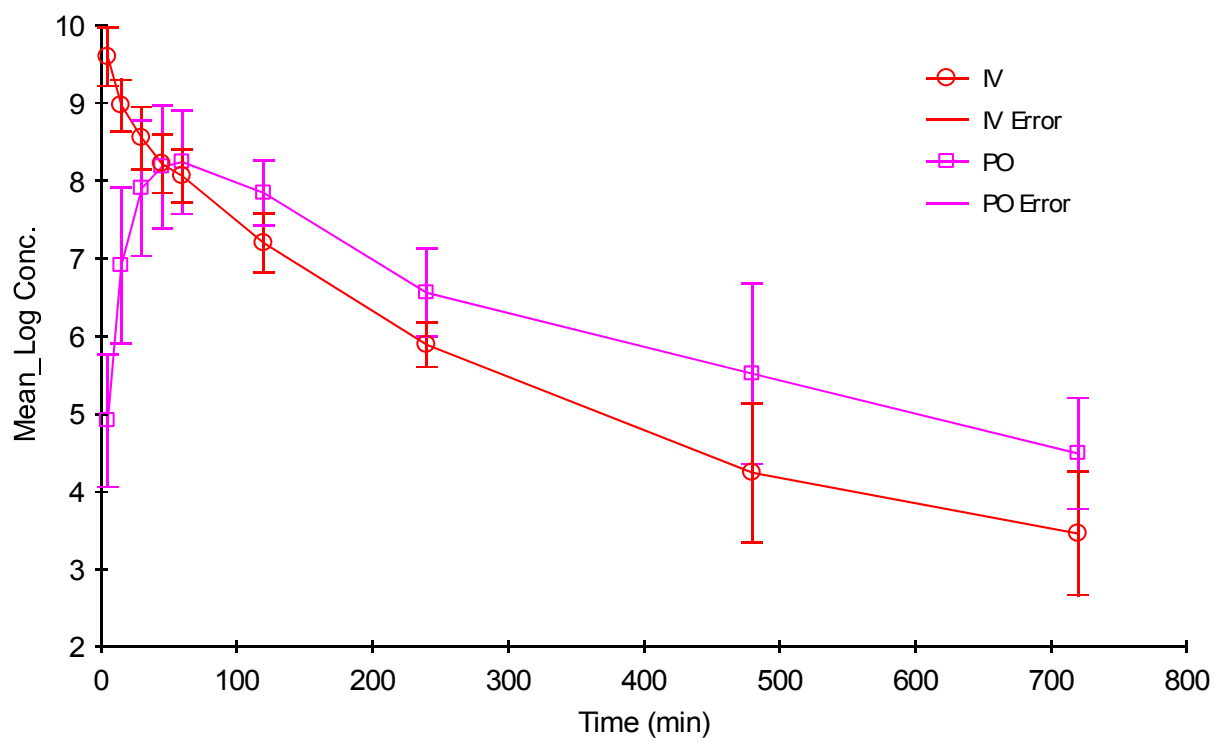

Figure 5-2. Rat plasma meanlog concentration - time plot of KZ-41 after a single dose $(10 \mathrm{mg} / \mathrm{kg}, \mathrm{n}=6)$. The curve without absorption peak is IV dose curve, the curve with a peak is oral dose curve. Each points represents the mean \pm S.D. 
Table 5-1. Key pharmacokinetic parameters of KZ-41 in rats $(n=6)$ calculated by mean concentrations versus time profile (Dose: $10 \mathrm{mg} / \mathrm{kg}$ ).

\begin{tabular}{lrrccccc}
\hline Route & $\begin{array}{c}\mathrm{C}_{\max } \\
\mathrm{ng} / \mathrm{mL}\end{array}$ & $\begin{array}{c}\mathrm{T}_{\max } \\
\min \end{array}$ & $\begin{array}{c}\mathrm{AUC} \\
\mathrm{min} \text { ug/mL }\end{array}$ & $\begin{array}{l}\mathrm{T}_{1 / 2} \\
\mathrm{~min}\end{array}$ & $\begin{array}{c}\mathrm{CL} \\
\mathrm{mL} / \mathrm{min} / \mathrm{kg}\end{array}$ & $\begin{array}{c}\mathrm{V}_{\mathrm{z}} \\
\mathrm{mL} / \mathrm{kg}\end{array}$ & $\mathrm{F}$ \\
\hline $\mathrm{IV}$ & 15688.7 & 5.0 & 722.2 & 183.1 & 13.8 & 3654.3 & \\
PO & 4591.3 & 45.0 & 803.1 & 147.7 & 12.1 & 2579.8 & $1.11^{*}$ \\
\hline \multirow{2}{*}{$\mathrm{p}=0.67}$. & & & & & & & \\
\end{tabular}


$100 \%$ may due to experimental error. T-test has been done to compare the AUC of i.v. to that of oral. The p-value was 0.67 . Statistically, bioavailability of KZ-41 in rat was $100 \%$. Key pharmacokinetic parameters of KZ-41 in individual rat by i.v. and oral administration were listed in Table 5-2 and Table 5-3 respectively.

\subsubsection{Microsomal Metabolic Stability}

KZ-41 was metabolically stable when incubated with pooled IGS SpragueDawley rat liver microsomes (Table 5-4.). The parent compound was about $100 \%$ remaining after 90 min incubation, while the positive control (propanolol) was 32\% remaining.

\subsubsection{Plasma Protein Binding}

The plasma protein binding data of KZ-41 is listed in Table 5-5. The plasma protein binding was moderate and not concentration dependent over the concentration range of $50 \mathrm{ng} / \mathrm{mL}$ to $5000 \mathrm{ng} / \mathrm{mL}$, with an average of $27.46 \%$ bound to plasma proteins. At concentrations of $50 \mathrm{ng} / \mathrm{mL}, 500 \mathrm{ng} / \mathrm{mL}$, and $5000 \mathrm{ng} / \mathrm{mL}$, the percentage of KZ-41 bound was $21.27 \%, 28.83 \%$, and $32.29 \%$ respectively.

\subsubsection{Bacterial Stability}

Bacteria Gluconobacter oxydans was unable to utilize KZ-41 as food by transforming it to another form (Figure 5-3). The parent compound KZ-41 remained $100 \%$ unchanged with cultured bacterial over $24 \mathrm{hr}$. As expected, QA was not stable in bacterial cultured media, less than $10 \%$ unchanged QA remained after one day.

\subsection{Discussion}

The present study demonstrates that KZ-41 had high oral bioavailability (about $100 \%$ ). This could be the result of numerous factors, including being stable with gut microflora, good absorption, slight first-pass metabolism in the intestinal wall and/or in the liver. First, KZ-41, not like QA, was not growth substrate target by bacteria Gluconobacter oxydans as we shown in bacterial stability study. It was stable in bacterial cultured medium. The enzymes responsible for QA transformation are quinate dehydrogenase (QDH), 3-dehydroquinate dehydratase (DQD), and 3-dehydroshikimate dehydratase. ${ }^{16,30,31} \mathrm{KZ}-41$ is not the substrate of QDH or DQD, may be the inhibitor of these enzymes of the bacterial. Further mechanism study is on going. Second, KZ-41 was well absorbed after oral administration, with a mean $\mathrm{C}_{\max }$ value of $4.59 \mu \mathrm{g} / \mathrm{mL}$ achieved at 45 min. KZ-41 is a highly water soluble small molecular QA amide, with molecular weight 233 and negative CLogP 2.03. Therefore, it appears to be permeable through the gastrointestinal tract. This suggestion is also evidenced by the fact that about $60 \%$ of the 
Table 5-2. Key pharmacokinetic parameters of KZ-41 in rats by intravenous administration (Dose: $10 \mathrm{mg} / \mathrm{kg}$ ).

\begin{tabular}{lrccccc}
\hline Animal & $\begin{array}{c}\mathrm{C}_{\max } \\
\mathrm{ng} / \mathrm{mL}\end{array}$ & $\begin{array}{c}\mathrm{T}_{\max } \\
\mathrm{min}\end{array}$ & $\begin{array}{c}\mathrm{AUC} \\
\mathrm{min} * \mathrm{ug} / \mathrm{mL}\end{array}$ & $\begin{array}{c}\mathrm{T}_{1 / 2} \\
\mathrm{~min}\end{array}$ & $\begin{array}{c}\mathrm{CL} \\
\mathrm{mL} / \mathrm{min} / \mathrm{kg}\end{array}$ & $\begin{array}{c}\mathrm{V}_{\mathrm{Z}} \\
\mathrm{mL} / \mathrm{kg}\end{array}$ \\
\hline 1 & 12760.0 & 5.0 & 637.4 & 202.2 & 15.3 & 4447 \\
2 & 24400.0 & 5.0 & 1024.3 & 136.6 & 9.7 & 1920 \\
3 & 24560.0 & 5.0 & 1070.2 & 147.4 & 9.2 & 1960 \\
4 & 12320.0 & 5.0 & 585.7 & 148.8 & 16.8 & 3600 \\
5 & 11920.0 & 5.0 & 530.1 & 149.8 & 18.6 & 404 \\
6 & 8948.0 & 5.0 & 473.4 & 131.5 & 21.0 & 3984 \\
Mean & 15818.0 & 5.0 & 720.2 & 152.7 & 15.1 & 3325.5 \\
S.D. & 6841.8 & 0.0 & 259.6 & 25.3 & 4.8 & 1106.4 \\
\hline
\end{tabular}


Table 5-3. Key pharmacokinetic parameters of KZ-41 in rats by oral administration (Dose: $10 \mathrm{mg} / \mathrm{kg}$ ).

\begin{tabular}{cccccccc}
\hline Animal & $\begin{array}{c}\mathrm{C}_{\max } \\
\mathrm{ng} / \mathrm{mL}\end{array}$ & $\begin{array}{c}\mathrm{T}_{\max } \\
\mathrm{min}\end{array}$ & $\begin{array}{c}\mathrm{AUC} \\
\mathrm{min} * \mathrm{ug} / \mathrm{mL}\end{array}$ & $\begin{array}{c}\mathrm{T}_{1 / 2} \\
\mathrm{~min}\end{array}$ & $\begin{array}{c}\mathrm{CL} \\
\mathrm{mL} / \mathrm{min} / \mathrm{kg}\end{array}$ & $\begin{array}{l}\mathrm{V}_{\mathrm{z}} \\
\mathrm{mL} / \mathrm{kg}\end{array}$ & $\mathrm{F}$ \\
\hline 1 & 4220.0 & 45.0 & 855.6 & 130.8 & 11.5 & 2164 & 1.19 \\
2 & 4284.0 & 45.0 & 858.2 & 147.6 & 11.3 & 2412 & 1.19 \\
3 & 1540.0 & 120.0 & 303.1 & 301.0 & 31.5 & 13677 & 0.42 \\
4 & 6192.0 & 60.0 & 1021.8 & 178.4 & 9.3 & 2390 & 1.42 \\
5 & 11680.0 & 45.0 & 1337.0 & 213.8 & 7.2 & 2230 & 1.86 \\
6 & 2668.0 & 45.0 & 447.0 & 130.5 & 22.0 & 4136 & 0.62 \\
Mean & 5097.3 & 60.0 & 803.8 & 183.7 & 15.5 & 4501.5 & \\
S.D. & 3592.1 & 30.0 & 378.3 & 65.8 & 9.4 & 4555.7 & \\
\hline
\end{tabular}


Table 5-4. KZ-41 rat liver microsomal stability study.

\begin{tabular}{|c|c|c|c|c|c|c|}
\hline \multirow[b]{2}{*}{ Time (Min) } & \multicolumn{2}{|l|}{ KZ-41 } & \multicolumn{2}{|c|}{ Positive control } & \multicolumn{2}{|c|}{ Negative control } \\
\hline & $\%$ Remaining & SD & $\%$ Remaining & $\mathrm{SD}$ & $\%$ Remaining & $\mathrm{SD}$ \\
\hline 0 & 100.0 & 13.3 & 100.0 & 9.0 & 100.0 & 9.3 \\
\hline 45 & 109.9 & & 32.1 & & 104.2 & \\
\hline 90 & 106.5 & & 42.3 & & 87.9 & \\
\hline
\end{tabular}

Positive control (propranolol), Negative control (propranolol with deactivated microsomes). 
Table 5-5. KZ-41 protein binding in rat plasma.

\begin{tabular}{cccc}
\hline Concentration, $\mathrm{ng} / \mathrm{mL}$ & \% Bound & \% Free drug & Standard deviation (\%) \\
\hline 50 & 21.27 & 78.73 & 10.01 \\
500 & 28.83 & 71.17 & 9.61 \\
5000 & 32.29 & 67.71 & 7.89 \\
Mean & 27.46 & 72.54 & 9.17 \\
\hline
\end{tabular}




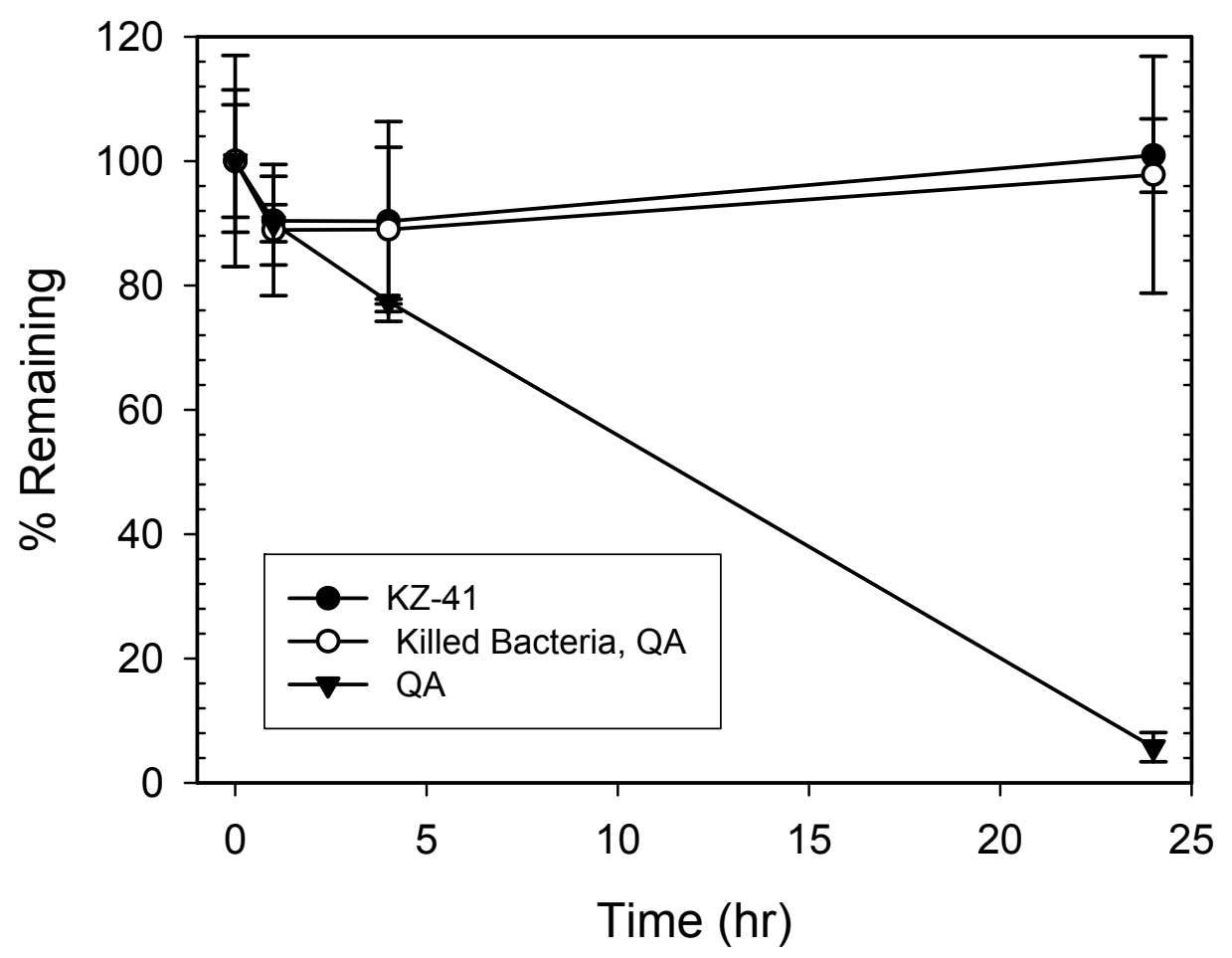

Figure 5-3. Bacterial stability of KZ-41. The parent compound KZ-41 remained 100\% unchanged with cultured bacteria over $24 \mathrm{hr}$. As expected, QA was not stable in bacterial cultured media, less than $10 \%$ unchanged QA remained after one day. 
administered dose was excreted in urine and feces. Third, the mean plasma clearance after i.v. administration was $13.8 \mathrm{~mL} / \mathrm{min} / \mathrm{kg}$, comparing to a typical hepatic blood flow of $55.2 \mathrm{~mL} / \mathrm{min} / \mathrm{kg}, 136$ the theoretical hepatic extraction ratio (ER) for this compound could be estimated as $25 \%(13.8 / 55.2)$. Considering first-pass inactivation alone, this would suggest that maximum oral bioavailability for KZ-41 could theoretically reach $75 \%(100 \%$-ER). The actually observed bioavailability of about $100 \%$ indicated there was almost no first-pass inactivation in the intestinal wall and/or the liver. It was supported by liver microsomal stability study data. Those data suggested that plasma clearance mainly come from renal and/or other routes.

The plasma protein binding of KZ-41 was moderate and not concentration dependent over the concentration range of $50 \mathrm{ng} / \mathrm{mL}$ to $5000 \mathrm{ng} / \mathrm{mL}$. This finding will be very useful when choosing dose in animal study, the higher dose will not cause dose dependent pharmacokinetics problems due to plasma protein binding.

\subsection{Conclusion}

In summary, KZ-41 was well absorbed with approximately $100 \%$ bioavailability after oral dose in rat. It was not the substrate of bacterial Gluconobacter oxydans. It has high aqueous solubility and metabolic stability. Its plasma protein binding was moderate. KZ-41 has good biopharmaceutical and pharmaceutics properties, is ideal for further development of an orally active anti-inflammatory drug. 


\section{CHAPTER 6. SUMMARY}

Quinic acid (QA) esters found in hot water extracts of Uncaria tomentosa (a.k.a. Cat's claw) exert anti-inflammatory activity through mechanisms involving inhibition of the pro-inflammatory transcription factor nuclear factor kappa B (NF- $\mathrm{B}$ ). Herein, we describe the synthesis and biological testing of novel QA derivatives. Inhibition of NF$\kappa \mathrm{B}$ was assessed using A549 (Type II alveolar epithelial-like) cells that stably express a secreted alkaline phosphatase (SEAP) reporter driven by an NF- $\kappa$ B response element. A549- NF- $\kappa$ B cells were stimulated with TNF- $\alpha(10 \mathrm{ng} / \mathrm{mL})$ in the presence or absence of QA derivative for 18 hours followed by measurement of SEAP activity. Amide substitution at the carboxylic acid position yielded potent inhibitors of NF- $\kappa$ B. A variety of modifications to the amide substitution were tolerated with the N-propyl amide derivative 3 being the most potent. Compound 3 was named as KZ-41. The NF- $\mathrm{B}$ inhibitory potency $\left(\mathrm{IC}_{50}\right)$ of our most active analog $\mathrm{KZ}-41$ was determined to be $2.83 \pm 1.76 \mu \mathrm{M}$. Further examination of the SAR demonstrated that acetylation of the hydroxyl groups reduced NF- $\kappa B$ inhibitory activity. QA amide derivatives lacked antioxidant activity and were found to be neither anti-proliferative nor cytotoxic at concentrations up to $100 \mu \mathrm{M}$.

We investigated the importance of the hydroxyl groups on the cyclohexane ring by preparing the dehydroquinate amide analogs. We hypothesized these modifications will retain anti-inflammatory activity with enhanced resistance to microbial degradation. The dehydroxyl QA amides 18 and 20 were prepared. They showed NF- $\kappa$ B inhibition at concentration $1 \mu \mathrm{M}$. The extent of NF- $\kappa \mathrm{B}$ inhibition was close to positive control drug dexamethasone. The dehydroxyl QA amide with a double bond $\mathbf{3 8}$ was also synthesized. The QA amide esters 24, 25, 29 and 33 were designed and synthesized to retain antiinflammatory activity with additional antioxidant properties. As expected, compound $\mathbf{2 5}$ showed strong anti-oxidant activity. Furthermore, they were hydrolyzed by the microflora, for an example, $\mathbf{2 5}$ was hydrolyzed into SA and 3. Both SA and $\mathbf{3}$ will not be consumed by gut bacteria, and are easily absorbed in animal digestive tract. This was done by other researchers, and not reported here.

To facilitate pre-clinical biopharmaceutic and pharmacokinetic (B/PK) studies of our lead QA amide analog KZ-41, we developed and validated a novel hydrophilic interaction liquid chromatography-tandem mass spectrometry (HILIC-MS/MS) analytical assay. An analog of KZ-41 was used as internal standard (IS). KZ-41 and the IS were obtained by protein precipitation and separated by HILIC chromatography using acetonitrile and water. A triple quadrupole mass spectrometer operating in the negative electrospray ionization mode with multiple reaction monitoring was used to detect KZ-41 and IS transitions of $\mathrm{m} / \mathrm{z} 232 \rightarrow 178$ and $272 \rightarrow 218$ respectively. The lower limit of quantification (LLOQ) was $0.5 \mathrm{ng} / \mathrm{mL}$ in plasma. The method was validated for selectivity, linearity, accuracy and precision in rat plasma. The ion suppression, recovery and stability of the analyte in the biological matrix were also tested. The assay developed is rapid, sensitive and robust enough to support preclinical B/PK studies of KZ-41. 
The study was also conducted to characterize the biopharmaceutics and preclinical pharmacokinetics of the lead QA amide analog, KZ-41. Rats (n=6/group) received a dose of either an i.v. or p.o. dose $(10 \mathrm{mg} / \mathrm{kg})$ of KZ-41. Pharmacokinetic parameters were determined from concentration - time profiles by non-compartmental analysis. Bacterial stability study was conducted in cultured bacterial gluconobacter oxydans. Plasma protein binding and metabolic stability were determined using equilibrium dialysis and rat liver microsomes respectively. Following i.v. administration, KZ-41 demonstrated a medium clearance $(15.1 \pm 4.8 \mathrm{~mL} / \mathrm{min} / \mathrm{kg})$, medium volume of distribution $(3.3 \pm 1.1 \mathrm{~L} / \mathrm{kg})$, and a terminal half-life of $2.6 \pm 0.4 \mathrm{hrs}$. KZ-41 was rapidly absorbed with complete oral bioavailability $(\mathrm{F} \approx 1)$, which was consistent with the fact that KZ-41 was not susceptible to degradation in bacterial and liver microsomal studies. KZ41 binding to plasma proteins was about $30 \%$. These studies demonstrate that new QA analog KZ-41 is an orally active anti-inflammatory agent.

In summary, we have discovered a novel series of non-toxic QA amides that potently inhibit NF- $\kappa \mathrm{B}$ activity in TNF- $\alpha$-stimulated human alveolar Type II-like epithelial cells (A549). The NF- $\mathrm{B}$ inhibitory potency $\left(\mathrm{IC}_{50}\right)$ of our most active analog KZ-41 was determined to be $2.83 \pm 1.76 \mu \mathrm{M}$. We have demonstrated that the QA analogs presented in this work do not exert their activity via anti-oxidant, cytotoxic, or carrageenan induced paw edema mechanisms. KZ-41 was rapidly absorbed with complete oral bioavailability $(\mathrm{F} \approx 1)$. It was not the substrate of bacterial Gluconobacter oxydans. It has high aqueous solubility and metabolic stability. Its plasma protein binding was moderate. KZ-41 has good biopharmaceutical and pharmaceutics properties, is idea for further development of an orally active anti-inflammatory drug. Mechanistic studies and pre-clinical efficacy studies of these newly designed compounds in various in vitro and in vivo models are on-going by other researchers, and are not reported in this dissertation. 


\section{LIST OF REFERENCES}

1. Sheng, Y.; Akesson, C.; Holmgren, K.; Bryngelsson, C.; Giamapa, V.; Pero, R. W. An active ingredient of Cat's claw water extracts identification and efficacy of quinic acid. $J$ Ethnopharmacol 2005, 96, 577-84.

2. Akesson, C.; Lindgren, H.; Pero, R. W.; Leanderson, T.; Ivars, F. Quinic acid is a biologically active component of the Uncaria tomentosa extract C-Med 100. Int Immunopharmacol 2005, 5, 219-29.

3. Sheng, Y.; Bryngelsson, C.; Pero, R. W. Enhanced DNA repair, immune function and reduced toxicity of C-MED-100, a novel aqueous extract from Uncaria tomentosa. J Ethnopharmacol 2000, 69, 115-26.

4. Sheng, Y.; Li, L.; Holmgren, K.; Pero, R. W. DNA repair enhancement of aqueous extracts of Uncaria tomentosa in a human volunteer study. Phytomedicine 2001, 8, 275-82.

5. Lamm, S.; Sheng, Y.; Pero, R. W. Persistent response to pneumococcal vaccine in individuals supplemented with a novel water soluble extract of Uncaria tomentosa, C-Med-100. Phytomedicine 2001, 8, 267-74.

6. Hofmann, F. C. Crells Ann 1790, II, 314.

7. Fisher, H. O. L.; Dangschat, G. Chem Ber 1932, 65, 1009-31.

8. Palmer, J. K. Occurrence of 1-quinic acid in tobacco leaves. Science 1957, 126, 504-5.

9. $\quad$ Rentschler, H.; Tanner, H. Chem Abstr 1954, 48, 9578.

10. Ting, S. V.; Deszyck, E. J. Isolation of 1-quinic acid in citrus fruit. Nature 1959, 183, 1404-5.

11. Hulme, A. C. The isolation of 1-quinic acid from the apple fruit. $J$ Exptl Botany 1957, 2, 298-9.

12. Anet, E.; Reynolds, T. M. Isolation of 1-quinic acid from the peach fruit. Nature 1953, 172, 1188-9.

13. Whiting, G. C.; Carr, J. G. Chlorogenic acid metabolism in cider fermentation. Nature 1957, 180, 1479.

14. Haslam, E.; Haworth, R. D.; Makinson, G. K. Synthesis of 3-O-pcoumaroylquinic acid. J Chem Soc 1961, 5153-6. 
15. Horler, D. F.; Nursten, H. E. The tannins of tara, caesalpinia spinosa (mol.) kuntze. J Chem Soc 1961, 3786-92.

16. Herrmann, K. M. The shikimate pathway: early steps in the biosynthesis of aromatic compounds. Plant Cell 1995, 7, 907-19.

17. Beaudoin-Eagan, L. D.; Thorpe, T. A. Turnover of shikimate pathway metabolites during shoot initiation in tobacco callus Plant Cell Physio 1984, 25, 913-21.

18. Maher, E. A.; Bate, N. J.; Ni, W.; Elkind, Y.; Dixon, R. A.; Lamb, C. J. lncreased disease susceptibility of transgenic tobacco plants with suppressed levels of preformed phenylpropanoid products. Proc Natl Acad Sci USA 1994, 91, 7802-6.

19. Davis, B. D.; Kalan, E. B.; Sprinson, D. B.; Srinivasan, P. R. The enzymatic conversion of sedoheptulose-1, 7-diphosphate to shikimic acid. J Biol Chem 1956, 223, 913-20.

20. Davis, B. D.; Kalan, E. B.; Sprinson, D. B.; Srinivasan, P. R. The conversion of various carbohydrates to 5 -dehydroskikimic acid by bacterial extracts. $J$ Biol Chem 1956, 223, 907-12.

21. Herrmann, K. M. The common aromatic biosynthetic pathway. Addison-Wesley: Reading, MA, 1983; p 301-22.

22. Pittard, A. J. Biosynthesis of the aromatic amino acids. American Society for Microbiology: Washington, DC, 1978; p 368-94.

23. Haslam, E. Shikimic acid: metabolism and metabolites. John Wiley and Sons: Chichester, 1993.

24. Chaudhuril, S.; Lambert, J. M.; Mccoll, L. A.; Coggins, J. R. Purification and characterization of 3-dehydroquinase from Escherichia coli. Biochem J 1986, 239, 699-704.

25. Whiting, G. C.; Coggins, R. A. The oxidation of D-quinate and related acids by Acetomonas oxydans. Biochem J 1967, 102, 283-93.

26. Giles, N. H.; Case, M. E.; Baum, J.; Geever, R.; Huiet, L.; Patel, V.; Tyler, B. Gene organization and regulation in the qa (quinic acid) gene cluster of Neurospora crassa. Microbiol Rev 1985, 49, 338-58.

27. Adamson, R. H.; Bridges, J. W.; Evans, M. E.; Williams, R. T. Species differences in the aromatization of quinic acid in vivo and the role of gut bacteria. Biochem J 1970, 116, 437-43. 
28. Adachi, O.; Yoshihara, N.; Tanasupawat, S.; Toyama, H.; Matsushita, K. Purification and characterization of membrane-bound quinoprotein quinate dehydrogenase. Biosci Biotechnol Biochem 2003, 67, 2115-23.

29. Gonzalez-Bello, C.; Castedo, L. Progress in type II dehydroquinase inhibitors: from concept to practice. Medicinal Research Reviews 2007, 27, 177-208.

30. Adachi, O.; Ano, Y.; Toyama, H.; Matsushita, K. High shikimate production from quinate with two enzymatic systems of acetic acid bacteria. Biosci Biotechnol Biochem 2006, 70, 2579-82.

31. Adachi, O.; Tanasupawat, S.; Yoshihara, N.; Toyama, H.; Matsushita, K. 3dehydroquinate production by oxidative fermentation and further conversion of 3dehydroquinate to the intermediates in the shikimate pathway. Biosci Biotechnol Biochem 2003, 67, 2124-31.

32. Blumenthal, M. The ABC clinical guide to herbs. American Botanical Council: Austin, 2003; p 23-38.

33. Aquino, R.; De Simone, F.; Pizza, C.; Conti, C.; Stein, M. L. Plant metabolites. Structure and in vitro antiviral activity of quinovic acid glycosides from Uncaria tomentosa and Guettarda platypoda. J Nat Prod 1989, 52, 679-85.

34. Aquino, R.; De Feo, V.; De Simone, F.; Pizza, C.; Cirino, G. Plant metabolites. New compounds and anti-inflammatory activity of Uncaria tomentosa. J Nat Prod 1991, 54, 453-9.

35. Rizzi, R.; Re, F.; Bianchi, A.; De Feo, V.; de Simone, F.; Bianchi, L.; Stivala, L. A. Mutagenic and antimutagenic activities of Uncaria tomentosa and its extracts. J Ethnopharmacol 1993, 38, 63-77.

36. Wurm, M.; Kacani, L.; Laus, G.; Keplinger, K.; Dierich, M. P. Pentacyclic oxindole alkaloids from Uncaria tomentosa induce human endothelial cells to release a lymphocyte-proliferation-regulating factor. Planta Med 1998, 64, 701-4.

37. Lemaire, I.; Assinewe, V.; Cano, P.; Awang, D. V.; Arnason, J. T. Stimulation of interleukin-1 and -6 production in alveolar macrophages by the neotropical liana, Uncaria tomentosa (una de gato). J Ethnopharmacol 1999, 64, 109-15.

38. Sheng, Y.; Pero, R. W.; Wagner, H. Treatment of chemotherapy-induced leukopenia in a rat model with aqueous extract from Uncaria tomentosa. Phytomedicine 2000, 7, 137-43. 
39. Sandoval, M.; Okuhama, N. N.; Zhang, X. J.; Condezo, L. A.; Lao, J.; Angeles, F. M.; Musah, R. A.; Bobrowski, P.; Miller, M. J. Anti-inflammatory and antioxidant activities of Cat's claw (Uncaria tomentosa and Uncaria guianensis) are independent of their alkaloid content. Phytomedicine 2002, 9, 325-37.

40. Keplinger, K.; Laus, G.; Wurm, M.; Dierich, M. P.; Teppner, H. Uncaria tomentosa (Willd.) DC.--ethnomedicinal use and new pharmacological, toxicological and botanical results. $J$ Ethnopharmacol 1999, 64, 23-34.

41. Wang, G. F.; Shi, L. P.; Ren, Y. D.; Liu, Q. F.; Liu, H. F.; Zhang, R. J.; Li, Z.; Zhu, F. H.; He, P. L.; Tang, W.; Tao, P. Z.; Li, C.; Zhao, W. M.; Zuo, J. P. Antihepatitis B virus activity of chlorogenic acid, quinic acid and caffeic acid in vivo and in vitro. Antiviral Res 2009, 83, 186-90.

42. Cho, A. S.; Jeon, S. M.; Kim, M. J.; Yeo, J.; Seo, K. I.; Choi, M. S.; Lee, M. K. Chlorogenic acid exhibits anti-obesity property and improves lipid metabolism in high-fat diet-induced-obese mice. Food Chem Toxicol 2010, 48, 937-43.

43. Yildiz, O. G.; Soyuer, S.; Saraymen, R.; Eroglu, C. Protective effects of caffeic acid phenethyl ester on radiation induced lung injury in rats. Clin Invest Med 2008, 31, E242-7.

44. Park, J. B. 5-Caffeoylquinic acid and caffeic acid orally administered suppress Pselectin expression on mouse platelets. J Nutr Biochem 2009, 20, 800-5.

45. Sandoval, M.; Charbonnet, R. M.; Okuhama, N. N.; Roberts, J.; Krenova, Z.; Trentacosti, A. M.; Miller, M. J. Cat's claw inhibits TNFalpha production and scavenges free radicals: role in cytoprotection. Free Radic Biol Med 2000, 29, 718.

46. Sandoval-Chacon, M.; Thompson, J.; Zhang, X.; Liu, X.; Mannick, E.; SadowskaKrowicka, H. Anti-inflammatory actions of Cat's claw: the role of NF-kappaB. Aliment Pharmacol Ther 1998, 12, 1279-89.

47. Aguilar, J. L.; Rojas, P.; Marcelo, A.; Plaza, A.; Bauer, R.; Reininger, E.; Klaas, C. A.; Merfort, I. Anti-inflammatory activity of two different extracts of Uncaria tomentosa (Rubiaceae). J Ethnopharmacol 2002, 81, 271-6.

48. Akesson, C.; Lindgren, H.; Pero, R. W.; Leanderson, T.; Ivars, F. An extract of Uncaria tomentosa inhibiting cell division and NF-kappa B activity without inducing cell death. Int Immunopharmacol 2003, 3, 1889-900. 
49. Yun, K. J.; Koh, D. J.; Kim, S. H.; Park, S. J.; Ryu, J. H.; Kim, D. G.; Lee, J. Y.; Lee, K. T. Anti-inflammatory effects of sinapic acid through the suppression of inducible nitric oxide synthase, cyclooxygase-2, and proinflammatory cytokines expressions via nuclear factor-kappaB inactivation. J Agric Food Chem 2008, 56, 10265-72.

50. Tak, P.; Firestein, G. NF-kappaB: a key role in inflammatory diseases. J Clin Invest 2001, 107, 7-11.

51. Hayden, M. S.; Ghosh, S. Signaling to NF-кB. Genes Dev. 2004, 18, 2195-224.

52. Ghosh, S.; May, M. J.; Kopp, E. B. NF-kB and Rel proteins: evolutionarily conserved mediators of immune responses. Annu Rev Immunol 1998, 16, 225-60.

53. Li, Q.; Verma, I. M. NF-kB regulation in the immune system. Nat Rev Immunol 2002, 2, 725-34.

54. Bonizzi, G.; Karin, M. The two NF-kB activation pathways and their role in innate and adaptive immunity. Trends Immunol 2004, 25, 280-8.

55. Perkins, N. D. Integrating cell-signalling pathways with NF-kappaB and IKK function. Nat Rev Mol Cell Biol 2007, 8, 49-62.

56. Bonizzi, G.; Karin, M. The two NF- $\kappa$ B activation pathways and their role in innate and adaptive immunity. Trends Immunol 2004, 25, 280-8

57. Gerondakis, S.; Grossmann, M.; Nakamura, Y.; Pohl, T.; Grumont, R. Genetic approaches in mice to understand Rel/NF- $\kappa \mathrm{B}$ and $\mathrm{I} \kappa \mathrm{B}$ function: transgenics and knockouts. Oncogene 1999, 18, 6888-95

58. Pasparakis, M.; Luedde, T.; Schmidt-Supprian, M. Dissection of the NF- $\kappa$ B signalling cascade in transgenic and knockout mice. Cell Death Differ 2006, 13, 861-72.

59. Pahl, H. L. Activators and target genes of Rel/NF- $\kappa \mathrm{B}$ transcription factors. Oncogene 1999, 18, 6853-66.

60. Yamamoto, Y.; Gaynor, R. B. Therapeutic potential of inhibition of the NFkappaB pathway in the treatment of inflammation and cancer. $J$ Clin Invest 2001, $107,135-42$.

61. Dacquisto, F.; May, M. J.; Ghosh, S. Inhibition of nuclear factor kappa B (NF-B): an emerging theme in anti-inflammatory therapies. Mol Interv 2002, 2, 22-35. 
62. Kracht, M. Targeting strategies to modulate the NF-kB and JNK signal transduction network. Anti-Inflammatory \& Anti-Allergy Agents in Medicinal Chemistry 2007, 6, 71-84.

63. Calzado, M. A.; Bacher, S.; Schmitz, M. L. NF-kappaB inhibitors for the treatment of inflammatory diseases and cancer. Curr Med Chem 2007, 14, 367-76.

64. Kono, Y.; Shibata, H.; Kodama, Y.; Sawa, Y. The suppression of the Nnitrosating reaction by chlorogenic acid. Biochem J 1995, 312 ( Pt 3), 947-53.

65. Grisham, M. B.; Ware, K.; Gilleland, H. E., Jr.; Gilleland, L. B.; Abell, C. L.; Yamada, T. Neutrophil-mediated nitrosamine formation: role of nitric oxide in rats. Gastroenterology 1992, 103, 1260-6.

66. Vink, J.; Cloos, J.; Kaspers, G. J. Proteasome inhibition as novel treatment strategy in leukaemia. Br J Haematol 2006, 134, 253-62.

67. Girard, C.; Dourlat, J.; Savarin, A.; Surcin, C.; Leue, S.; Escriou, V.; Largeau, C.; Herscovici, J.; Scherman, D. Sialyl Lewis (x) analogs based on a quinic acid scaffold as the fucose mimic. Bioorg Med Chem Lett 2005, 15, 3224-8.

68. Kaila, N.; Somers, W. S.; Thomas, B. E.; Thakker, P.; Janz, K.; DeBernardo, S.; Tam, S.; Moore, W. J.; Yang, R.; Wrona, W.; Bedard, P. W.; Crommie, D.; Keith, J. C., Jr.; Tsao, D. H.; Alvarez, J. C.; Ni, H.; Marchese, E.; Patton, J. T.; Magnani, J. L.; Camphausen, R. T. Quinic acid derivatives as sialyl Lewis (x)-mimicking selectin inhibitors: design, synthesis, and crystal structure in complex with Eselectin. J Med Chem 2005, 48, 4346-57.

69. Pietta, P.G. Flavonoids as antioxidants. J Nat Prod 2000, 63, 1035-42.

70. Pero, R. W.; Lund, H.; Leanderson, T. Antioxidant metabolism induced by quinic acid: increased urinary excretion of tryptophan and nicotinamide. Phytotherapy Research 2009, 23, 335-46

71. Zeng, K.; Thompson, K. E.; Yates, C. R.; Miller, D. D. Synthesis and biological evaluation of quinic acid derivatives as anti-inflammatory agents. Bioorg Med Chem Lett 2009, 19, 5458-60.

72. Jiang, R. W.; Lau, K. M.; Hon, P. M.; Mak, T. C.; Woo, K. S.; Fung, K. P. Chemistry and biological activities of caffeic acid derivatives from Salvia miltiorrhiza. Curr Med Chem 2005, 12, 237-46.

73. Gonthier, M. P.; Verny, M. A.; Besson, C.; Remesy, C.; Scalbert, A. Chlorogenic acid bioavailability largely depends on its metabolism by the gut microflora in rats. J Nutr 2003, 133, 1853-9. 
74. Azuma, K.; Ippoushi, K.; Nakayama, M.; Ito, H.; Higashio, H.; Terao, J. Absorption of chlorogenic acid and caffeic acid in rats after oral administration. $J$ Agric Food Chem 2000, 48, 5496-500.

75. Farah, A.; Monteiro, M.; Donangelo, C. M.; Lafay, S. Chlorogenic acids from green coffee extract are highly bioavailable in humans. $J$ Nutr 2008, 138, 2309-15.

76. Moridani, M. Y.; Scobie, H.; Jamshidzadeh, A.; Salehi, P.; O'Brien, P. J. Caffeic acid, chlorogenic acid, and dihydrocaffeic acid metabolism: glutathione conjugate formation. Drug Metab Dispos 2001, 29, 1432-9.

77. Plumb, G. W.; Garcia-Conesa, M. T.; Kroon, P. A.; Rhodes, M., Ridley, S.; Williamson, G. Metabolism of chlorogenic acid by human plasma, liver, intestine and gut microflora. J Sci Food Agric 1999, 79, 390-2.

78. Couteau, D.; McCartney, A. L.; Gibson, G. R.; Williamson, G.; Faulds, C. B. Isolation and characterization of human colonic bacteria able to hydrolyse chlorogenic acid. J Appl Microbiol 2001, 90, 873-81.

79. Booth, A. N.; Williams, R. T. Dehydroxylation of caffeic acid by rat and rabbit caecal contents and sheep rumen liquor. Nature (Lond.) 1963, 198, 684-5

80. Rice-Evans, C. A.; Miller, N. J.; Paganga, G. Structure-antioxidant activity relationships of flavonoids and phenolic acids. Free Radic Biol Med 1996, 20, 933-56.

81. Glasser, G.; Graefe, E. U.; Struck, F.; Veit, M.; Gebhardt, R. Comparison of antioxidative capacities and inhibitory effects on cholesterol biosynthesis of quercetin and potential metabolites Phytomedicine 2002, 9, 33-40.

82. Lautemann, E. Juatus Liebigs Annln Chem 1863, 125, 9.

83. Quick, A. J. The conjugation of benzoic acid in man. J biol Chem 1931, 92, 65-85.

84. Beer, C. T.; Dickens, F.; Pearson, J. The aromatization of hydrogenated derivatives of benzoic acid in animal tissues. Biochem J 1951, 48, 222-37.

85. Cotran, R.; Kendrick, M. I.; Kass, E. H. Proc Soc Exp Biol Med 1960, 104, 424.

86. Martin, A. K. The origin of urinary aromatic compounds excreted by ruminants. The metabolism of quinic, cyclohexanecarboxylic and non-phenolic aromatic acids to benzoic acid. Br J Nutr 1982, 47, 139-54.

87. Grewe, R.; Lorenzen, W.; Vining, L. Chem Ber 1954, 87, 793-802.

88. Smissman, E. E.; Oxman, M. A. J Am Chem Soc 1963, 85, 2184. 
89. Wolinsky, J.; Novak, R.; Vasileff, R. A sterospecific synthesis of quinic acid. $J$ Org Chem 1964, 29, 3596-8.

90. Barco, A.; Benetti, S.; Risi, C. D.; Marchetti, P.; Pollini, G. P.; Zanirato, V. D(-)-Quinic acid: a chiron store for natural product synthesis Tetrahedron: Asymmetry 1997, 8, 3515-45.

91. Kim, C. U.; Lew, W.; Williams, M. A.; Liu, H.; Zhang, L.; Swaminathan, S.; Bischofberger, N.; Chen, M. S.; Mendel, D. B.; Tai, C. Y.; Laver, W. G.; Stevens, R. C. Influenza neuraminidase inhibitors possessing a novel hydrophobic interaction in the enzyme active site: design, synthesis, and structural analysis of carbocyclic sialic acid analogues with potent anti-influenza activity. $J$ Am Chem Soc 1997, 119, 681-90.

92. Metaferia, B. B.; Ray, S.; Smith, J. A.; Bewley, C. A. Design and synthesis of substrate-mimic inhibitors of mycothiol-Sconjugate amidase from Mycobacterium tuberculosis. Bioorganic \& Medicinal Chemistry Letters 2007, 17, 444-7.

93. Sanchez-Sixto, C.; Prazeres, V. F. V.; Castedo, L.; Lamb, H.; Hawkins, A. R.; Gonzalez-Bello, C. Structure-based design, synthesis, and biological evaluation of inhibitors of mycobacterium tuberculosis type II dehydroquinase. J Med Chem 2005, 48, 4871-81.

94. Payne, R. J.; Peyrot, F.; Kerbarh, O.; Abell, A. D.; Abell, C. Rational design, synthesis, and evaluation of nanomolar type II dehydroquinase inhibitors. Chem Med Chem 2007, 2, 1015-29.

95. Sefkow, M.; Kelling, A.; Schilde, U. First efficient syntheses of 1-, 4-, and 5caffeoylquinic acid. Eur J Org Chem 2001, 2735-42.

96. Sefkow, M. First efficient synthesis of chlorogenic acid. Eur J Org Chem 2001, 1137-41.

97. Harborne, J. B.; Baxter, H. Phytochemical dictionary Taylor \& Francis: London, 1993.

98. Metaferia, B. B.; Chen, L.; Baker, H. L.; Huang, X. Y.; Bewley, C. A. Synthetic macrolides that inhibit breast cancer cell migration in vitro. J Am Chem Soc 2007, $129,2434-5$.

99. Uppenbrink, J.; Mervis, J. An information revolution. Science 2000, 287, 1951.

100. Szuromi, P.; Vinson, V.; Marshall, E. Rethinking drug discovery. Science 2004, 303, 1795.

101. Mervis, J. Inside the pipeline: pharma goes to work. Science 2005, 309, 721. 
102. Drews, J. Drug discovery: a historical perspective. Science 2000, 287, 1960-4.

103. Sams-Dodd, F. Target-based drug discovery: is something wrong? Drug Discov Today 2005, 10, 139-47.

104. Brown, D. Unfinished business: target-based drug discovery. Drug Discov Today 2007, 12, 1007-12.

105. Brown, D.; Superti-Furga, G. Rediscovering the sweet spot in drug discovery. Drug Discov Today 2003, 8, 1067-77.

106. Knowles, J.; Gromo, G. A guide to drug discovery: target selection in drug discovery. Nat Rev Drug Discov 2003, 2, 63-9.

107. Lindsay, M. A. Target discovery. Nat Rev Drug Discov 2003, 2, 831-8.

108. Haak, V. D. Industry Success Rates; CMR Report 2004, 04-234A.

109. FDA. Innovation and Stagnation: Challenge and Opportunity on the Critical Path to New Medical Products; FDA White Paper: 2004, http://www.fda.gov/oc/initiatives/criticalpath/whitepaper.html.

110. Butcher, E. C. Can cell systems biology rescue drug discovery? Nat Rev Drug Discov 2005, 4, 461-7.

111. Ho, R. L.; Lieu, C. A. Systems biology: an evolving approach in drug discovery and development. Drugs $R$ D 2008, 9, 203-16.

112. Williams, J. E. Review of antiviral and immunomodulating properties of plants of the Peruvian rainforest with a particular emphasis on Una de Gato and Sangre de Grado. Altern Med Rev 2001, 6, 567-79.

113. Akesson, C.; Pero, R. W.; Ivars, F. C-Med 100, a hot water extract of Uncaria tomentosa, prolongs lymphocyte survival in vivo. Phytomedicine 2003, 10, 23-33.

114. Boyd, S. A.; Fung, A. K.; Baker, W. R.; Mantei, R. A.; Stein, H. H.; Cohen, J.; Barlow, J. L.; Klinghofer, V.; Wessale, J. L.; Verburg, K. M.; et al. Nonpeptide renin inhibitors with good intraduodenal bioavailability and efficacy in dog. $J$ Med Chem 1994, 37, 2991-3007.

115. Rohloff, J. C.; Kent, K. M.; Postich, M. J.; W., B. M.; Chapman, H. H.; Kelly, D. E.; Lew, W.; Louie, M. S.; McGee, L. R.; Prisbe, E. J.; Schultze, L. M.; Yu, R. H.; Zhang, L. Practical total synthesis of the anti-influenza drug GS-4104. J Org Chem 1998, 63, 4545-50. 
116. Zhou, K.; Yin, J. J.; Yu, L. L. Phenolic acid, tocopherol and carotenoid compositions, and antioxidant functions of hard red winter wheat bran. J Agric Food Chem 2005, 53, 3916-22.

117. Moon, K. Y.; Hahn, B. S.; Lee, J.; Kim, Y. S. A cell-based assay system for monitoring NF-kappaB activity in human HaCat transfectant cells. Anal Biochem 2001, 292, 17-21.

118. Yates, C.; Zeng, K.; Miller, D.; Thompson, K. Anti-inflammatory quinic acid derivatives for oral administration PCT Int Appl 2009 WO/2009/062200.

119. Zeng, K.; Thompson, K. E.; Yates, C. R.; Miller, D. D. Synthesis and biological evaluation of quinic acid derivatives as anti-inflammatory agents. Bioorg Med Chem Lett 2009, 5458-60.

120. Su, Z.; Paquette, L. A. Conversion of D-(-)-quinic acid into an enantiopure C-4 functionalized 2-Iodocyclohexenone acetal. J Org Chem 1995, 60, 764-6.

121. Gao, M.; Mock, B. H.; Hutchins, G. D.; Zheng, Q. H. Synthesis and initial PET imaging of new potential dopamine D3 receptor radioligands (E)-4,3,2[11C]methoxy-N-4-(4-(2-methoxyphenyl)piperazin-1-yl)butyl-cinnamoylamid es. Bioorg Med Chem 2005, 13, 6233-43.

122. Lesuisse, D.; Berchtold, G. A. (-) - Methyl 4,5 - o-benzylidene-4-epi-shikimate: an intermediate for the synthsis of (-)-chorismic acid analogues. J Org Chem 1985, $50,888-90$.

123. Bartlett, P. A.; Maitra, U.; Chouinard, P. M. Synthesis of "Iso-EPSP" and evaluation of its interaction with chorismate synthase. $\mathrm{J} \mathrm{Am} \mathrm{Chem} \mathrm{Soc} \mathrm{1986,} \mathrm{108,}$ 8068-71.

124. Gonzalez, C.; Carballido, M.; Castedo, L. Synthesis of polyhydroxycyclohexanes and relatives from (-) - quinic acid. J Org Chem 2003, 68, 2248-55.

125. Erk, T.; Bergmann, H.; Richling, E. A novel method for the quantification of quinic acid in food using stable isotope dilution analysis. $J A O A C$ Int 2009, 92, 730-3.

126. Molnar-Perl, I. Role of chromatography in the analysis of sugars, carboxylic acids and amino acids in food. $J$ Chromatogr A 2000, 891, 1-32.

127. Hrobonová, K.; Lehotay, J.; Cizmárik, J. Determination of quinic and shikimic acids in products derived from bees and their preparates by HPLC. Journal of Liquid Chromatography \& Related Technologies 2007, 30, 2635-44. 
128. Paek, I. B.; Moon, Y.; Ji, H. Y.; Kim, H. H.; Lee, H. W.; Lee, Y. B.; Lee, H. S. Hydrophilic interaction liquid chromatography-tandem mass spectrometry for the determination of levosulpiride in human plasma. J Chromatogr B Analyt Technol Biomed Life Sci 2004, 809, 345-50.

129. Naidong, W. Bioanalytical liquid chromatography tandem mass spectrometry methods on underivatized silica columns with aqueous/organic mobile phases. $J$ Chromatogr B Analyt Technol Biomed Life Sci 2003, 796, 209-24.

130. Lee, H. W.; Ji, H. Y.; Kim, H. Y.; Park, E. S.; Lee, K. C.; Lee, H. S. Determination of metoclopramide in human plasma using hydrophilic interaction chromatography with tandem mass spectrometry. J Chromatogr B Analyt Technol Biomed Life Sci 2009, 877, 1716-20.

131. Nguyen, H. P.; Schug, K. A. The advantages of ESI-MS detection in conjunction with HILIC mode separations: fundamentals and applications. J Sep Sci 2008, 31, 1465-80.

132. Hsieh, Y. Potential of HILIC-MS in quantitative bioanalysis of drugs and drug metabolites. J Sep Sci 2008, 31, 1481-91.

133. Matuszewski, B.; Constanzer, M.; Chavez-Eng, C. Strategies for the assessment of matrix effect in quantitative bioanalytical methods based on HPLC-MS/MS Anal Chem 2003, 75, 3019-30.

134. Sprecher, M.; Srinivasan, P. R.; Sprinson, D. B.; Davis, B. D. The biosynthesis of tyrosine from labeled glucose in Escherichia coli. Biochemistry 1965, 4, 2855-60.

135. Srinivasan, P. R.; Shigeura, H. T.; Sprecher, M.; Sprinson, D. B.; Davis, B. D. The biosynthesis of shikimic acid from D-glucose. J Biol Chem 1956, 220, 47797.

136. Davies, B.; Morris, T. Physiological parameters in laboratory animals and humans. Pharm Res 1993, 10, 1093-5. 


\section{VITA}

Kui Zeng was born in Jiangxi, China in October 1967. He received his Bachelor of Science degree from China Agricultural University in 1989. In 1997, Mr. Zeng came to the United States. In 1999, he received a Master of Science degree in Chemistry from Jackson State University. In 2003, he received another Master of Science degree in Computer Sciences from Jackson State University. Mr. Zeng enrolled in the Doctor of Philosophy program in the Department of Pharmaceutical Sciences at the University of Tennessee Health Science Center, Memphis in January 2005. He expects to complete his Pharmaceutical Sciences doctorate in May 2010. 